Article

\title{
Synthesis and Antiproliferative Evaluation of 3-Chloroazetidin-2-ones with Antimitotic Activity: Heterocyclic Bridged Analogues of Combretastatin A-4
}

\author{
Azizah M. Malebari ${ }^{1,+}{ }^{\dagger}$ Shu Wang ${ }^{2,+}{ }^{+}$Thomas F. Greene ${ }^{2}$, Niamh M. O’Boyle ${ }^{2} \oplus$, Darren Fayne ${ }^{3}$, \\ Mohemmed Faraz Khan ${ }^{3}{ }^{(D}$, Seema M. Nathwani ${ }^{4}$, Brendan Twamley ${ }^{5}$, Thomas McCabe ${ }^{5}$, \\ Daniela M. Zisterer ${ }^{4}$ and Mary J. Meegan ${ }^{2, *}$
}

Citation: Malebari, A.M.; Wang, S.; Greene, T.F.; O’Boyle, N.M.; Fayne, D.; Khan, M.F.; Nathwani, S.M.; Twamley, B.; McCabe, T.; Zisterer, D.M.; et al. Synthesis and Antiproliferative Evaluation of 3-Chloroazetidin-2-ones with Antimitotic Activity: Heterocyclic Bridged Analogues of Combretastatin A-4. Pharmaceuticals 2021, 14, 1119. https://doi.org/10.3390/ph14111119

Academic Editor: Dhimant Desai

Received: 14 October 2021

Accepted: 28 October 2021

Published: 31 October 2021

Publisher's Note: MDPI stays neutral with regard to jurisdictional claims in published maps and institutional affiliations.

Copyright: (c) 2021 by the authors. Licensee MDPI, Basel, Switzerland. This article is an open access article distributed under the terms and conditions of the Creative Commons Attribution (CC BY) license (https:// creativecommons.org/licenses/by/ $4.0 /)$.
1 Department of Pharmaceutical Chemistry, College of Pharmacy, King Abdulaziz University, Jeddah 21589, Saudi Arabia; amelibary@kau.edu.sa

2 School of Pharmacy and Pharmaceutical Sciences, Trinity College Dublin, Trinity Biomedical Sciences Institute, 152-160 Pearse Street, Dublin 2, DO2R590 Dublin, Ireland; wangsh@tcd.ie (S.W.); tgreene@tcd.ie (T.F.G.); Niamh.OBoyle@tcd.ie (N.M.O.)

3 Molecular Design Group, School of Biochemistry and Immunology, Trinity College Dublin, Trinity Biomedical Sciences Institute, 152-160 Pearse Street, Dublin 2, DO2R590 Dublin, Ireland; FAYNED@tcd.ie (D.F.); mfkhan@tcd.ie (M.F.K.)

4 School of Biochemistry and Immunology, Trinity College Dublin, Trinity Biomedical Sciences Institute, 152-160 Pearse Street, Dublin 2, DO2R590 Dublin, Ireland; seema.nathwani@outlook.com (S.M.N.); dzistrer@tcd.ie (D.M.Z.)

5 School of Chemistry, Trinity College Dublin, Dublin 2, DO2R590 Dublin, Ireland; TWAMLEYB@tcd.ie (B.T.); TMCCABE@tcd.ie (T.M.)

* Correspondence: mmeegan@tcd.ie; Tel.: +353-1-896-2798; Fax: +353-1-896-2793

+ Co-First Authors: contributed equally to the work.

Abstract: Antimitotic drugs that target tubulin are among the most widely used chemotherapeutic agents; however, the development of multidrug resistance has limited their clinical activity. We report the synthesis and biological properties of a series of novel 3-chloro- $\beta$-lactams and 3,3 -dichloro- $\beta$-lactams (2-azetidinones) that are structurally related to the tubulin polymerisation inhibitor and vascular targeting agent, Combretastatin A-4. These compounds were evaluated as potential tubulin polymerisation inhibitors and for their antiproliferative effects in breast cancer cells. A number of the compounds showed potent activity in MCF-7 breast cancer cells, e.g., compound 10n (3-chloro-4-(3-hydroxy-4-methoxy-phenyl)-1-(3,4,5-trimethoxyphenyl)azetidin-2-one) and compound 11n (3,3-dichloro-4-(3-hydroxy-4-methoxyphenyl)-1-(3,4,5-trimethoxyphenyl)-azetidin-2-one), with $\mathrm{IC}_{50}$ values of 17 and $31 \mathrm{nM}$, respectively, and displayed comparable cellular effects to those of Combretastatin A-4. Compound 10n demonstrated minimal cytotoxicity against non-tumorigenic HEK-293T cells and inhibited the in vitro polymerisation of tubulin with significant $\mathrm{G}_{2} / \mathrm{M}$ phase cell cycle arrest. Immunofluorescence staining of MCF-7 cells confirmed that $\beta$-lactam 10n caused a mitotic catastrophe by targeting tubulin. In addition, compound 10n promoted apoptosis by regulating the expression of pro-apoptotic protein BAX and anti-apoptotic proteins Bcl-2 and Mcl-1. Molecular docking was used to explore the potential molecular interactions between novel 3-chloro- $\beta$-lactams and the amino acid residues of the colchicine binding active site cavity of $\beta$-tubulin. Collectively, these results suggest that 3-chloro-2-azetidinones, such as compound 10n, could be promising lead compounds for further clinical anti-cancer drug development.

Keywords: $\beta$-lactam; 3-chloroazetidin-2-ones; antimitotic; antiproliferative activity; breast cancer; tubulin polymerisation; colchicine-binding site; combretastatin A-4

\section{Introduction}

Microtubules play an essential role in many cellular functions, such as cell division and mitosis, and are investigated as attractive drug targets in anti-cancer chemotherapy. Many 
structurally diverse compounds that interfere with microtubule dynamics and spindle formation have been identified. Microtubule-targeting agents (MTAs) have an important role as cancer chemotherapy drugs, e.g., taxol, which stabilises microtubules, and the vinca alkaloids vincristine, vinblastine and vinorelbine, which inhibit the formation of microtubules in the mitotic spindle [1]. These drugs arrest cells in the $G_{2} / M$ phase of the cell cycle and effectively target and disrupt mitosis. However, the clinical application of MTAs is restricted by their severe adverse effects [2]. Recent developments in antibodydrug conjugates (ADCs) have resulted in the introduction of effective MTAs for therapeutic use, e.g., ado-trastuzumab emtansine (T-DM1, Kadcyla ${ }^{\circledR}$ ), comprised of the humanised anti-HER2 IgG1 trastuzumab linked to the anti-mitotic agent, mertansine [3].

MTAs that interact with the following primary tubulin binding sites have been identified: the vinca alkaloid, laulimalide, paclitaxel, epothilone, maytansine, rhizoxin, pironetin, PM060184 [4], colchicine 1a and other sites (Figure 1) [5]. Ravelli reported the first structural description of DAMA-colchicine $\mathbf{1 b}$ binding in tubulin in 2004 [6]. To date, the structures of many diverse ligands complexed at the colchicine binding site of tubulin have been characterised using X-ray crystallography. Colchicine is not in clinical use as a drug in cancer treatment due to its narrow therapeutic index [7]. Many structural modifications of colchicine are reported in vitro with the objective of lowering colchicine toxicity [8,9], while the various colchicine binding site ligands, such as combretastatin A-4 2a, are an extensively investigated group of MTAs, with several currently in clinical trials. In addition, molecules such as CA-4 that bind to the colchicine site have been intensively investigated as vascular-targeting agents (VTAs) [10].

The stilbene combretastatin A-4 (CA-4) 2a isolated in 1989 by Pettit from the bark of the South African Bush tree Combretum caffrum [11] has provided a scaffold structure for the extensive investigation of structure-activity relationships in the stilbene series. CA-4P (fosbretabulin $\mathbf{2 b}$, Figure 1), a water-soluble phosphate prodrug of CA-4 is in phase II/III clinical trials, either alone or in combination with chemotherapeutic agents such as cisplatin [12,13]. Potent anti-vascular properties have also been demonstrated for CA-1(2c) and the related phosphate prodrug (2d), OXi4503 (Figure 1) [10,14]. The bibenzyl compound erianin $2 \mathbf{e}$ is a novel apoptosis-inducing anti-angiogenic agent [15]. The synthetic benzophenone phenstatin $\mathbf{3 a}$ and phosphate prodrug $\mathbf{3 b}$ show potent cytotoxic activity in cancer cells together with microtubule-destabilising activity [16], while the isoCombretastatin 3c, a stable non-natural isomer of CA-4, shows equivalent anti-cancer properties to CA-4 [17].

To prevent the cis-trans isomerisation associated with the storage, metabolism and administration of CA-4 [18,19], bridging heterocyclic analogues of CA-4 have been developed with the objective of restricting the cis configuration and optimising the solubility and bioactivity. Examples of diverse carbocyclic and heterocyclic ring systems have been reported, which replace the alkene of CA-4, constrain the aryl rings A and B in a cis configuration and demonstrate useful microtubule targeting and anti-cancer activity [20,21]. Many diverse heterocyclic compounds related in structure to colchicine have been identified as MTAs and some examples are illustrated in Figure 1. DJ101 4a, a novel metabolically stable indolylimidazopyridine containing the 3,4,5-trimethoxyphenyl substituent characteristic of colchicine and CA-4, depolymerises microtubules and is effective against a broad panel of metastatic melanomas and is effective in overcoming P-gp-mediated multidrug resistance (MDR) [22].

Trimethoxyphenyl-1,2,3-triazole hybrids, such as $4 \mathbf{b}$, containing the coumarin fragment, inhibit human gastric MGC803 cancer cell growth, induce $\mathrm{G}_{2} / \mathrm{M}$ phase arrest by down-regulating the expression of CDK1, promote apoptosis by regulating Death Receptor 5 (DR5) and the Bcl-2 family of proteins and inhibit tubulin polymerisation by interacting with the colchicine site [23]. The quinaldinyl-iso-carbazolyl compound 5a is more active than CA-4 1a and isoCA-4 3c against A549, lung adenocarcinoma epithelial cells [24]. The novel benzoxazepine $5 \mathbf{b}$, related in structure to isoCA-4 $\mathbf{3} \mathbf{c}$, displays significant cytotoxicity against HCT116 and K562 cancer cell lines, and inhibits tubulin polymerisation and 
induces $\mathrm{G}_{2} / \mathrm{M}$ arrest (Figure 1) [25]. The 4-aryl-4H-chromene Crolibulin 6 binds to the colchicine-binding site on beta-tubulin and has undergone a Phase I/II clinical trial for anaplastic thyroid cancer [26]. The crystal structure of tubulin complexed with crolibulin 6 has been determined [27] and revealed that the chromene moiety of crolibulin adopts a similar position as the $B$ and $C$ rings of colchicine, while not containing the characteristic 3,4,5-trimethoxyphenyl ring. Although it is more deeply buried in $\beta$-tubulin, it is closer to some hydrophobic amino acids than colchicine.

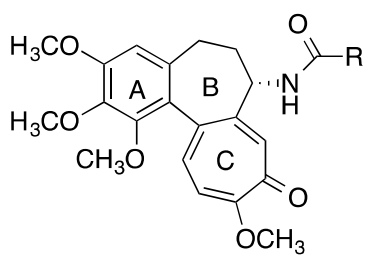

1a Colchicine $\mathrm{R}=\mathrm{CH}_{3}$ 1b DAMA-Colchicine $\mathrm{R}=\mathrm{CH}_{2} \mathrm{SH}$<smiles>[R]c1c(/C=C\c2cc(OC)c(OC)c(OC)c2)ccc(OC)c1OC</smiles>

2a CA-4 $\mathrm{R}_{1}=\mathrm{R}_{2}=\mathrm{H}$

2b $\mathrm{R}_{1}=\mathrm{PO}_{3} \mathrm{Na}_{2}, \mathrm{R}_{2}=\mathrm{H}$

2c $\mathrm{CA}-1 \mathrm{R}_{1}=\mathrm{H}$. $\mathrm{R}_{2}=\mathrm{OH}$

2d $\mathrm{R}_{1}=\mathrm{PO}_{3} \mathrm{Na}_{2}, \mathrm{R}_{2}=\mathrm{OPO}_{3} \mathrm{Na}_{2}$<smiles>COc1ccc(CCc2cc(OC)c(OC)c(OC)c2)cc1O</smiles>

2e Erianin<smiles>[X]C(c1ccc(OC)c(O)c1)c1cc(OC)c(OC)c(OC)c1</smiles>

3a Phenstatin $\mathrm{R}=\mathrm{H}, \mathrm{X}=\mathrm{CH}_{2}$ 3b $\mathrm{R}=\mathrm{PO}_{3} \mathrm{Na}_{2}, \mathrm{X}=\mathrm{CH}_{2}$

3c Isocombretastatin A4, R=H, X=O<smiles>COc1cc(-c2nccc3[nH]c(-c4cccc5[nH]ccc45)nc23)cc(OC)c1OC</smiles>

4a DJ101<smiles>COc1ccc(CN(C(=O)n2cc(COc3ccc4c(C)cc(=O)oc4c3)nn2)c2cc(OC)c(OC)c(OC)c2)cc1</smiles><smiles>C=C(c1ccc2c(c1)c1ccccc1n2C)c1cc(C)nc2ccccc12</smiles>

5 a<smiles></smiles>

$5 b$<smiles>COc1cc(C2C(C#N)=C(N)Oc3c2ccc(N)c3N)cc(Br)c1OC</smiles>

6 Crolibulin<smiles>CC(C)(C)c1[nH]cnc1/C=c1\[nH]c(=O)/c(=C/c2ccccc2)[nH]c1=O</smiles>

7 Plinabulin<smiles>Nc1cc(-c2cc(N3CCOCC3)nc(N3CCOCC3)n2)c(C(F)(F)F)cn1</smiles>

8 Buparlisib BKM120

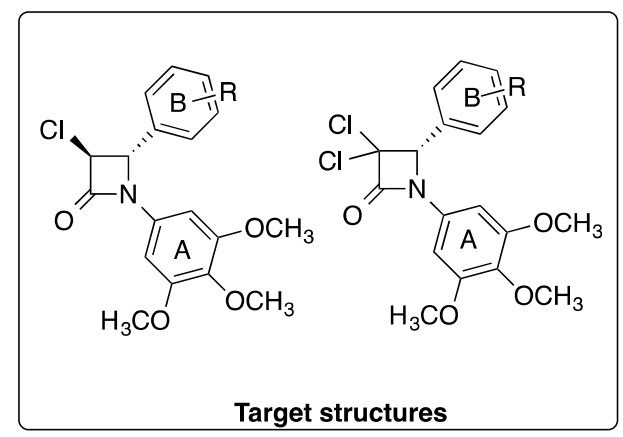

Figure 1. Colchicine (1a), DAMA-Colchicine 1b, Combretastatins 2a-2d, erianin 2e, phenstatins 3a, 3b, isocombretastatin 3c, colchicine binding site inhibitors 4a (DJ101), 4b, quinolines 5a, 5b, Crolibulin 6, Plinabulin 7, Buparlisib BKM120 8 and target $\beta$-lactam structures. 
It is interesting to observe that the orally active diketopiperazine plinabulin 7 selectively targets and binds to the colchicine-binding site of tubulin [28], blocks tumour growth [29] and provides early protection against severe neutropenia induced by chemotherapy in patients with advanced NSCLC (Figure 1) [30]. BKM120 (Buparlisib) 8 is one of the most advanced phosphoinositide 3-kinase (PI3K) inhibitors for the treatment of cancer, but it has been shown to also interfere with microtubule polymerisation as an off-target effect [31]. Although considerable progress has been achieved in the discovery of targeted cancer therapies, both innate and acquired mechanisms of resistance are commonly observed for many successful cancer drugs [32].

We have reported the synthesis, antiproliferative and tubulin-binding effects of a series of 2-azetidinones ( $\beta$-lactams), containing the structural features of CA-4, while retaining the necessary cis configuration of Rings A and B [33,34]. $\beta$-Lactam compounds containing aryl and heterocycles such as thiophene located at C-3 were found to be particularly effective [35-37]. In addition, both the anti-angiogenic and anti-migratory effects observed in MDA-MB-231 breast adenocarcinoma cells suggest a potential anti-metastatic role for these compounds [38]. We have identified the $\beta$-lactam heterocycle as a potential scaffold for the development of new anti-tumour agents and wished to establish the structural requirements for substituents at $\mathrm{C}-3$.

The anti-cancer activity of structurally diverse monocyclic $\beta$-lactam compounds has been previously reported [39-46]. Chiral azetidin-2-ones were designed as nonisomerisable CA-4 analogues disrupting tubulin polymerisation, inducing cellular apoptosis and suppressing angiogenesis [47-49]. 3-Hydroxy-1,4-diaryl-2-azetidinones induce apoptosis, with the activation of AMP-activated protein kinase (AMPK) in colon cancer [50], while 3-methoxy- $\beta$-lactams show a significant decrease in AKT kinase activity, a cell survival pathway identified in breast cancer [51]. Piperazine modified azetidinone derivatives suppress proliferation and migration in human cervical cancer HeLa cells [52]. Interestingly, 1,3-disubstituted cyclobutane-containing analogues of combretastatin A4 were evaluated for their cytotoxic properties in human cancer cell lines HepG2 (hepatocarcinoma) and SK-N- DZ (neuroblastoma) [53]. Although $\beta$-lactam antibiotics such as penicillins and cephalosporins are best known for their antibacterial activities [54], antimicrobial [55,56], antifungal [57,58] and anti-filarial [59] activities have also been demonstrated for monocyclic $\beta$-lactams.

We now report a series of novel 3-chloro-2-azetidinone and 3,3-dichloro-2-azetidinone compounds with an interesting profile, particularly in triple negative breast cancer, which could be considered for potential development as tubulin destabilising agents in preclinical studies of breast cancer (see Figure 1, target structures). A library of 1,4-diarylazetidin-2-ones that contain halogen substituents chloro, dichloro or bromo at C-3 was prepared for evaluation. The $\beta$-lactam ring forms a rigid scaffold for the hydrophobic CA-4 aryl rings $\mathrm{A}$ and $\mathrm{B}$ required for interaction with the colchicine binding site of tubulin. The effect of these C-3 halogen substituents on the biological activity of these compounds when the cis configuration (Rings A and B) is constrained into the 4-membered azetidin-2-one ring structure was investigated. The synthesis of the phosphate ester prodrugs of the most potent 3-chloro-1,4-diarylazetidin-2-one was also examined, to increase the potential bioavailability of the compound. The introduction of this halogen substituent at C-3 also allowed us to examine potential structure-activity relationships for the series, and to rationalise the effect of the introduction of the C-3 chlorine on the interaction with the colchicine binding site. We have now investigated a new series of novel 3-halo-2-azetidinone compounds with an improved biochemical profile, e.g., in triple negative breast cancer for potential development in the treatment of breast cancer as tubulin destabilising agents. These novel heterocyclic structures were further investigated for their effects on cell viability, cell cycle and tubulin polymerisation in MCF-7 breast cancer cells. 


\section{Results and Discussion}

\subsection{Chemistry}

The azetidinones required for the present study were prepared using the Staudinger ketene-imine cycloaddition reaction. The imines $9 \mathbf{a}-9 \mathrm{~s}$ were obtained using a condensation reaction of the 3,4,5-trimethoxyaniline with the appropriately substituted benzaldehyde, Scheme 1. The silyl ether compound $9 \mathrm{~m}$ was initially obtained by a reaction of 91 with tertbutyldimethylsilyl chloride (TBDMSCl) in a 78\% yield; however, a cleaner silyl ether product $9 \mathrm{~m}$ was obtained if the protection was carried out first on 3-hydroxy-4methoxybenzaldehyde (94\%). 3-((tert-Butyldimethylsilyl)oxy)-4-methoxybenzaldehyde was then reacted with 3,4,5-trimethoxyaniline to afford the protected imine $9 \mathrm{~m}$ in a $76 \%$ yield. The silyl ether was removed under mild conditions at a later stage in the synthetic route without the degradation of the $\beta$-lactam ring. The compounds $\mathbf{9 a}-\mathbf{9} \mathbf{s}$ contain a 3,4,5-trimethoxyaryl ring at $\mathrm{N}-1$, present in ring A of CA-4, together with a second aryl ring positioned at the $\mathrm{C}-4$ position of the $\beta$-lactam ring containing various substituents (Ring B). Alternative approaches were investigated for the preparation of the 3,5-dimethoxyphenyl substituted imines $9 \mathbf{w}$ and $9 \mathbf{x}$ to optimise the yield and purity of the product, e.g., use of isopropanol as a solvent, and sulfuric acid, benzoic acid or boric acid as a catalyst. However, optimum yields for compounds $9 w$ and $9 x$ (97 and $85 \%$, respectively) were obtained when these reactions were carried out in aqueous conditions and at an ambient temperature for less than one hour, Scheme 1 [60]. Imines $\mathbf{9 t}-\mathbf{9 v}$ were prepared using a condensation reaction of the 3,4,5-trimethoxybenzaldehyde with the appropriately substituted anilines and allowed for the positioning of the 3,4,5-trimethoxyaryl Ring A at C-4 of the $\beta$-lactam. Imines $9 \mathbf{w}$ and $\mathbf{9 x}$ are designed to replace the 3,4,5-trimethoxyaryl Ring A with the alternative 3,5-dimethoxyphenyl substitution. This substitution pattern is characteristic of stilbenes such as resveratrol $\left(3,4^{\prime}, 5\right.$-trihydroxystilbene) identified as having therapeutic and chemopreventive roles in colorectal and skin cancers [61,62], and is also present in the related stilbenes pinosylvin, isorhapontigenin, pterostilbene $[63,64]$, which also elicit anti-cancer properties. The structure of the imine $\mathbf{9 0}$ was confirmed using X-ray crystallography (Figure 2 and Table 1 ) showing the $E$ configuration of the imine with an N1-C2 bond length of $1.280(2) \AA$. The torsion angle between the $\mathrm{N}=\mathrm{C}-\mathrm{C}$-phenyl ring was determined as $-175.33^{\circ}$, while the torsion angel for the $\mathrm{C}=\mathrm{N}-\mathrm{C}$ - phenyl ring was $-34.4^{\circ}$. The packing structure assumed by the products was centrosymmetric and monoclinic.

The Staudinger reaction $([2+2]$ ketene-imine cycloaddition reaction) is a versatile method for the synthesis of 2-azetidinones. Ketenes are usually formed in situ by a reaction of acyl halides with tertiary amines. However, 2-azetidinones are also directly accessible from imines and carboxylic acids via mixed anhydrides [65], using activating agents such as methoxymethylene- $N, N$-dimethyliminium salt, [66], the Vilsmeier reagent, the Mukaiyama reagent and triphosgene [67]. 3-Chloro-3-thioaryl- $\beta$-lactams, obtained by the chlorination of 3-thioaryl- $\beta$-lactams with sulfuryl chloride, are reported as suitable substrates for Lewis acid catalysed nucleophilic substitution reactions [68]. In the present work, the Staudinger reaction of the imines $\mathbf{9 a}-\mathbf{9 k}$ and $\mathbf{9 m}-\mathbf{9 s}$ with chloroacetyl chloride in the presence of triethylamine (Scheme 2 ) afforded the $\beta$-lactam products $10 \mathbf{a}-\mathbf{m}$ and $\mathbf{1 0 o}$ as racemic mixtures in yields of $3-57 \%$. Compound $\mathbf{1 0 1}$ was also obtained in a reaction of the imine 91 with chloroacetic acid with triphosgene as the acid activating agent. Deprotection of the silyl ether $\mathbf{1 0 1}$ with TBAF afforded the phenolic product 10n. Low yields in some of the Staudinger reactions were due to the degradation of the imine commonly observed in these reaction mixtures. 
<smiles>[R]c1ccc(/N=C/c2c([R])ccc(/C=N/c3cc(OC)c(OC)c(OC)c3)c2OC)c([R])c1[R]</smiles>

9a: $R^{1}=R^{2}=R^{3}=H$

9b: $R^{1}=C l, R^{2}=R^{3}=H$

9c: $R^{1}=B r, R^{2}=R^{3}=H$

9d: $R^{1}=\mathrm{NO}_{2}, \mathrm{R}^{2}=\mathrm{R}^{3}=\mathrm{H}$

9e: $R^{1}=\mathrm{OCH}_{3}, \mathrm{R}^{2}=\mathrm{R}^{3}=\mathrm{H}$

9f: $R^{1}=\mathrm{OCH}_{2} \mathrm{CH}_{3}, \mathrm{R}^{2}=\mathrm{R}^{3}=\mathrm{H}$

9g: $R^{1}=O P h, R^{2}=R^{3}=H$

9h: $R^{1}=\mathrm{OCH}_{2} \mathrm{Ph}, \mathrm{R}^{2}=\mathrm{R}^{3}=\mathrm{H}$

9i: $\quad R^{1}=\mathrm{SCH}_{3}, \mathrm{R}^{2}=\mathrm{R}^{3}=\mathrm{H}$

9j: $R^{1}=\mathrm{H}, \mathrm{R}^{2} \mathrm{R}^{3}=\mathrm{CH}=\mathrm{CH}-\mathrm{CH}=\mathrm{CH}$

9k: $\mathrm{R}^{1} \mathrm{R}^{2}=\mathrm{CH}=\mathrm{CH}-\mathrm{CH}=\mathrm{CH}, \mathrm{R}^{3}=\mathrm{H}$

(b)

9l: $R^{1}=\mathrm{OCH}_{3}, \mathrm{R}^{2}=\mathrm{OH}, \mathrm{R}^{3}=\mathrm{H}$

9m: $\mathrm{R}^{1}=\mathrm{OCH}_{3}, \mathrm{R}^{2}=\mathrm{OTBDMS}, \mathrm{R}^{3}=\mathrm{H}$

9n: $\mathrm{R}^{1}=\mathrm{OCH}_{3} ; \mathrm{R}^{2}=\mathrm{NO}_{2}, \mathrm{R}^{3}=\mathrm{H}$

9o: $R^{1}=\mathrm{SCH}_{2} \mathrm{CH}_{3}, \mathrm{R}^{2}=\mathrm{R}^{3}=\mathrm{H}$

9p: $\mathrm{R}^{1}=\mathrm{OCH}_{3}, \mathrm{R}^{2}=\mathrm{CH}_{3}, \mathrm{R}^{3}=\mathrm{H}$

9q: $R^{1}=\mathrm{OCH}_{3}, \mathrm{R}^{2}=\mathrm{F}, \mathrm{R}^{3}=\mathrm{H}$

9r: $R^{1}=\mathrm{OCH}_{3}, \mathrm{R}^{2}=\mathrm{Cl}, \mathrm{R}^{3}=\mathrm{H}$

9s: $\mathrm{R}^{1}=\mathrm{OCH}_{3}, \mathrm{R}^{2}=\mathrm{Br}, \mathrm{R}^{3}=\mathrm{H}$<smiles>[R]c1ccc(N)cc1</smiles>

(a)<smiles>[R]c1ccc(/N=C/c2cc(OC)c(OC)c(OC)c2)cc1</smiles>

9t: $\mathrm{R}^{1}=\mathrm{OCH}_{3}$

9u: $\mathrm{R}^{1}=\mathrm{OCH}_{2} \mathrm{CH}_{3}$

9v: $\mathrm{R}^{1}=\mathrm{SCH}_{3}$<smiles>[R]c1ccc(C=O)cc1</smiles>

(c)<smiles>[R1]c1ccc(/C=N/c2cc(OC)cc(OC)c2)cc1</smiles>

9w: $\mathrm{R}^{1}=\mathrm{OCH}_{3}$

Scheme 1. Synthesis of imines 9a-x. Reagents and conditions: (a) EtOH, conc. $\mathrm{H}_{2} \mathrm{SO}_{4}$, reflux, 4 h (70-92\%); (b) TBDMSCl, DBU, $\mathrm{CH}_{2} \mathrm{Cl}_{2}, 20{ }^{\circ} \mathrm{C}$ (78\%); (c) $\mathrm{H}_{2} \mathrm{O}, 30 \mathrm{~min}, 20{ }^{\circ} \mathrm{C}(85-97 \%)$. 


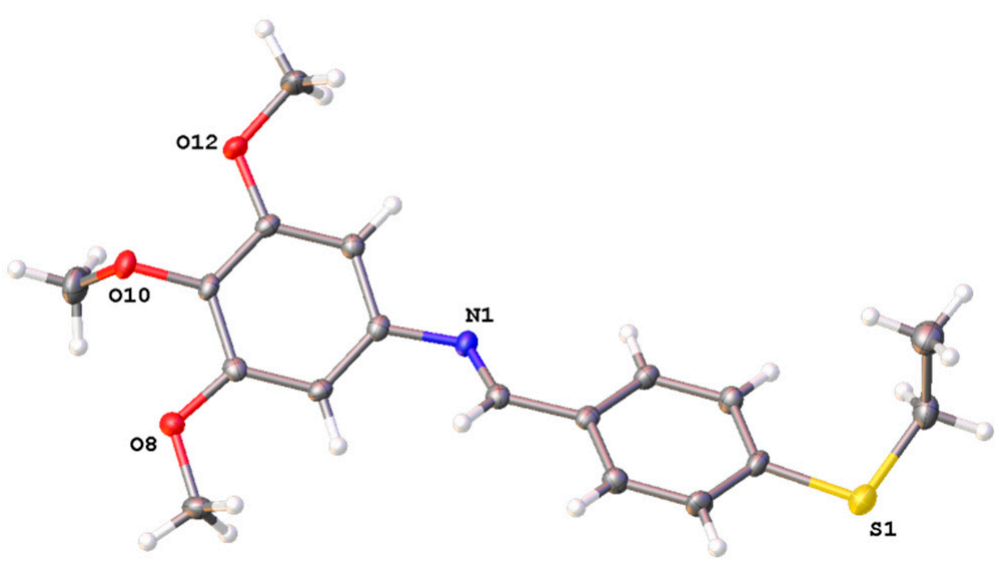

Figure 2. ORTEP representation of the X-ray crystal structure of compound 9o with the thermal ellipsoids set at $50 \%$ probability.

Table 1. Crystal Data and Structure Refinement Details for compounds 9o, 10e, 10o/16g and 11o.

\begin{tabular}{|c|c|c|c|c|}
\hline Identification Code & 90 & $10 \mathrm{e}$ & $10 \mathrm{o} / 16 \mathrm{~g}$ & 110 \\
\hline CCDC number & 2077515 & 2077516 & 2077517 & 2077518 \\
\hline Empirical formula & $\mathrm{C}_{18} \mathrm{H}_{21} \mathrm{NO}_{3} \mathrm{~S}$ & $\mathrm{C}_{19} \mathrm{H}_{20} \mathrm{ClNO}_{5}$ & $\mathrm{C}_{19} \mathrm{H}_{19} \mathrm{Br}_{0.25} \mathrm{Cl}_{1.75} \mathrm{NO}_{5}$ & $\mathrm{C}_{20} \mathrm{H}_{21} \mathrm{Cl}_{2} \mathrm{NO}_{5}$ \\
\hline$M(\mathrm{~g} / \mathrm{mol})$ & 331.42 & 377.81 & 423.37 & 426.28 \\
\hline$T(K)$ & $100(2)$ & $93(2)$ & $100(2)$ & $100(2)$ \\
\hline Crystal System & monoclinic & monoclinic & monoclinic & orthorhombic \\
\hline SG & $\mathrm{P} 2_{1} / \mathrm{c}$ & $\mathrm{P} 2{ }_{1} / \mathrm{n}$ & $\mathrm{P} 2_{1} / \mathrm{n}$ & Pbca \\
\hline$a(\AA)$ & $12.3686(4)$ & $10.138(2)$ & $10.3414(3)$ & $11.2765(7)$ \\
\hline$b(\AA)$ & $10.1330(3)$ & $9.840(2)$ & $10.0786(3)$ & $12.5130(6)$ \\
\hline$c(\AA)$ & $13.8346(5)$ & $18.357(4)$ & $17.9994(6)$ & $27.9482(15)$ \\
\hline$\alpha\left({ }^{\circ}\right)$ & 90 & 90 & 90 & 90 \\
\hline$\beta\left(^{\circ}\right)$ & $100.7347(12)$ & $95.46(3)$ & $96.2023(15)$ & 90 \\
\hline$\gamma\left({ }^{\circ}\right)$ & 90 & 90 & 90 & 90 \\
\hline$V\left(\AA^{3}\right)$ & $1703.56(10)$ & $1822.9(6)$ & $1865.04(10)$ & $3943.6(4)$ \\
\hline Z & 4 & 4 & 4 & 8 \\
\hline $\operatorname{Dcalc}\left(\mathrm{g} / \mathrm{cm}^{3}\right)$ & 1.292 & 1.377 & 1.508 & 1.436 \\
\hline$\mu\left(\mathrm{mm}^{-1}\right)$ & 0.204 & 0.239 & 0.879 & 0.361 \\
\hline $\mathrm{F}(000)$ & 704.0 & 792.0 & 874.0 & 1776.0 \\
\hline Crystal size $\left(\mathrm{mm}^{3}\right)$ & $0.162 \times 0.08 \times 0.05$ & $0.320 \times 0.280 \times 0.260$ & $0.38 \times 0.36 \times 0.12$ & $0.38 \times 0.06 \times 0.05$ \\
\hline Radiation & $\operatorname{Mo} K \alpha(\lambda=0.71073)$ & Mo $K \alpha(\lambda=0.71073)$ & $\operatorname{Mo} K \alpha(\lambda=0.71073)$ & $\operatorname{Mok} \alpha(\lambda=0.71073)$ \\
\hline \multirow[t]{2}{*}{ Reflections collected } & 54356 & 16596 & 20607 & 11396 \\
\hline & 3907 & 4026 & 4649 & 3614 \\
\hline \multirow[t]{2}{*}{ Independent reflections } & $\mathrm{R}_{\mathrm{int}}=0.0396$ & $\mathrm{R}_{\mathrm{int}}=0.0226$ & $R_{\text {int }}=0.0439$ & $\mathrm{R}_{\mathrm{int}}=0.0534$ \\
\hline & $\mathrm{R}_{\text {sigma }}=0.0188$ & $\mathrm{R}_{\text {sigma }}=0.0175$ & $R_{\text {sigma }}=0.0369$ & $R_{\text {sigma }}=0.0648$ \\
\hline Data/restraints/parameters & $3907 / 0 / 212$ & $4026 / 0 / 235$ & $4649 / 8 / 251$ & $3614 / 1 / 246$ \\
\hline Goodness-of-fit on $F^{2}(S)$ & 1.049 & 1.079 & 1.036 & 1.078 \\
\hline Final $\mathrm{R}$ indexes $(I \geq 2 \sigma(I)) *$ & $\begin{array}{r}\mathrm{R}_{1}=0.0430 \\
\mathrm{wR}_{2}=0.1126\end{array}$ & $\begin{array}{r}\mathrm{R}_{1}=0.0364 \\
\mathrm{wR}_{2}=0.0877\end{array}$ & $\begin{array}{r}\mathrm{R}_{1}=0.0313 \\
\mathrm{w} \mathrm{R}_{2}=0.0741\end{array}$ & $\begin{array}{r}\mathrm{R}_{1}=0.0525 \\
\mathrm{wR}_{2}=0.1026\end{array}$ \\
\hline Final R indexes (all data) & $\begin{array}{r}\mathrm{R}_{1}=0.0565 \\
\mathrm{wR}_{2}=0.1207\end{array}$ & $\begin{array}{r}\mathrm{R}_{1}=0.0373 \\
\mathrm{wR}_{2}=0.0882\end{array}$ & $\begin{array}{r}\mathrm{R}_{1}=0.0441 \\
\mathrm{wR}_{2}=0.0795\end{array}$ & $\begin{array}{c}\mathrm{R}_{1}=0.0779 \\
\mathrm{wR}_{2}=0.1126\end{array}$ \\
\hline $\begin{array}{l}\text { Largest diff. peak/hole/e } \\
\AA^{-3}\end{array}$ & $0.66 /-0.55$ & $0.35 /-0.25$ & $0.35 /-0.38$ & $0.30 /-0.45$ \\
\hline
\end{tabular}

${ }^{*} \mathrm{R}_{1}=\sum|| \mathrm{F}_{\mathrm{o}}|-| \mathrm{F}_{\mathrm{c}}|| / \sum\left|\mathrm{F}_{\mathrm{o}}\right|, \mathrm{wR}_{2}=\left[\sum \mathrm{w}\left(\mathrm{F}_{\mathrm{o}}{ }^{2}-\mathrm{F}_{\mathrm{c}}{ }^{2}\right)^{2} / \sum \mathrm{w}\left(\mathrm{F}_{\mathrm{o}}{ }^{2}\right)^{2}\right]^{1 / 2}$. 
<smiles>[R]c1ccc([C@@H]2[C@H](Cl)C(=O)N2c2cc(OC)c(OC)c(OC)c2)c([R])c1[R]</smiles>

10a: $R^{1}=R^{2}=R^{3}=H$

10b: $\mathrm{R}^{1}=\mathrm{Cl} ; \mathrm{R}^{2}=\mathrm{R}^{3}=\mathrm{H}$

10c: $R^{1}=B r ; R^{2}=R^{3}=H$

10d: $R^{1}=\mathrm{NO}_{2} ; \mathrm{R}^{2}=\mathrm{R}^{3}=\mathrm{H}$

10e: $\mathrm{R}^{1}=\mathrm{OCH}_{3} ; \mathrm{R}^{2}=\mathrm{R}^{3}=\mathrm{H}$ cis

10e: $\mathrm{R}^{1}=\mathrm{OCH}_{3} ; \mathrm{R}^{2}=\mathrm{R}^{3}=\mathrm{H}$ trans

10f: $\mathrm{R}^{1}=\mathrm{OCH}_{2} \mathrm{CH}_{3} ; \mathrm{R}^{2}=\mathrm{R}^{3}=\mathrm{H}$

10g: $R^{1}=O P h ; R^{2}=R^{3}=H$

10h: $\mathrm{R}^{1}=\mathrm{OCH}_{2} \mathrm{Ph} ; \mathrm{R}^{2}=\mathrm{R}^{3}=\mathrm{H}$

10i: $\mathrm{R}^{1}=\mathrm{SCH}_{3}, \mathrm{R}^{2}=\mathrm{R}^{3}=\mathrm{H}$

10j: $R^{1}=H, R^{2} R^{3}=\mathrm{CH}=\mathrm{CH}-\mathrm{CH}=\mathrm{CH}$

10k: $\mathrm{R}^{1} \mathrm{R}^{2}=\mathrm{CH}=\mathrm{CH}-\mathrm{CH}=\mathrm{CH} ; \mathrm{R}^{3}=\mathrm{H}$

(c)

10l: $\mathrm{R}^{1}=\mathrm{OCH}_{3} ; \mathrm{R}^{2}=\mathrm{OTBDMS}, \mathrm{R}^{3}=\mathrm{H}$

10m: $\mathrm{R}^{1}=\mathrm{OCH}_{3} ; \mathrm{R}^{2}=\mathrm{NO}_{2}, \mathrm{R}^{3}=\mathrm{H}$

10n: $\mathrm{R}^{1}=\mathrm{OCH}_{3}, \mathrm{R}^{2}=\mathrm{OH}, \mathrm{R}^{3}=\mathrm{H}$

10o: $\mathrm{R}^{1}=\mathrm{OCH}_{3}, \mathrm{R}^{2}=\mathrm{Cl}, \mathrm{R}^{3}=\mathrm{H}$

11a: $R^{1}=R^{2}=R_{3}=H$

11b: $\mathrm{R}^{1}=\mathrm{Cl} ; \mathrm{R}^{2}=\mathrm{R}_{3}=\mathrm{H}$

11c: $R^{1}=B r ; R^{2}=R^{3}=H$

11d: $\mathrm{R}^{1}=\mathrm{NO}_{2} ; \mathrm{R}^{2}=\mathrm{R}^{3}=\mathrm{H}$

11e: $R^{1}=\mathrm{OCH}_{3} ; R^{2}=\mathrm{R}^{3}=\mathrm{H}$

11f: $R^{1}=\mathrm{OCH}_{2} \mathrm{CH}_{3} ; \mathrm{R}^{2}=\mathrm{R}^{3}=\mathrm{H}$

11g: $R^{1}=O P h ; R^{2}=R^{3}=H$

11h: $\mathrm{R}^{1}=\mathrm{OCH}_{2} \mathrm{Ph} ; \mathrm{R}^{2}=\mathrm{R}^{3}=\mathrm{H}$

11i: $R^{1}=\mathrm{SCH}_{3}, \mathrm{R}^{2}=\mathrm{R}^{3}=\mathrm{H}$

11j: $R^{1}=\mathrm{H}, \mathrm{R}^{2} \mathrm{R}^{3}=\mathrm{CH}=\mathrm{CH}-\mathrm{CH}=\mathrm{CH}$

11k: $\mathrm{R}^{1} \mathrm{R}^{2}=\mathrm{CH}=\mathrm{CH}-\mathrm{CH}=\mathrm{CH} ; \mathrm{R}^{3}=\mathrm{H}$

11: $\mathrm{R}^{1}=\mathrm{OCH}_{3} ; \mathrm{R}^{2}=\mathrm{OTBDMS}, \mathrm{R}^{3}=\mathrm{H}$

(c)

11m: $\mathrm{R}^{1}=\mathrm{OCH}_{3} ; \mathrm{R}^{2}=\mathrm{NO}_{2}, \mathrm{R}^{3}=\mathrm{H}$

11n: $\mathrm{R}^{1}=\mathrm{OCH}_{3}, \mathrm{R}^{2}=\mathrm{OH}, \mathrm{R}^{3}=\mathrm{H}$

110: $R^{1}=\mathrm{OCH}_{3}, R^{2}=\mathrm{CH}_{3}, R^{3}=\mathrm{H}$<smiles>[R]c1ccc(N2C(=O)[C@@H](Cl)[C@H]2c2cc(OC)c(OC)c(OC)c2)cc1</smiles>

(a)<smiles>[R]c1ccc(/N=C/c2cc(OC)c(OC)c(OC)c2)cc1</smiles>

(b)<smiles>[R]c1ccc(N2C(=O)C(Cl)(Cl)[C@H]2c2cc(OC)c(OC)c(OC)c2)cc1</smiles>

12a: $\mathrm{R}=\mathrm{OCH}_{3}$

12b: $\mathrm{R}=\mathrm{OCH}_{2} \mathrm{CH}_{3}$

$9 t-v$

13a: $\mathrm{R}=\mathrm{OCH}_{3}$

12c: $\mathrm{R}=\mathrm{SCH}_{3}$

13b: $\mathrm{R}=\mathrm{OCH}_{2} \mathrm{CH}_{3}$<smiles>[R]Oc1cc(OC)cc(N2C(=O)[C@H](Cl)[C@H]2c2ccc([R])cc2)c1</smiles>

(a)<smiles>[R]c1ccc(/C=N/c2ccc([R])cc2)cc1</smiles>

(b)<smiles>[R]Oc1cc(OC)cc(N2C(=O)C(Cl)(Cl)[C@H]2c2ccc([R])cc2)c1</smiles>

14a: $\mathrm{R}=\mathrm{OCH}_{3}$ 14b: $\mathrm{R}=\mathrm{OCH}_{2} \mathrm{CH}_{3}$

$9 w, x$

5a: $\mathrm{R}=\mathrm{OCH}_{3}$ 15b: $\mathrm{R}=\mathrm{OCH}_{2} \mathrm{CH}_{3}$

Scheme 2. Synthesis of $\beta$-lactams 10a-o, 11a-o, 12a-c, 13a-c, 14a-b and 15a-b. Reagents and conditions: (a) (i) $\mathrm{ClCH}_{2} \mathrm{COCl}$,

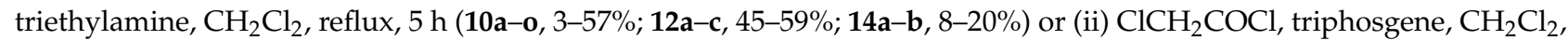
reflux, $6 \mathrm{~h}$ (10n, 34\%); (b) $\mathrm{Cl}_{2} \mathrm{CHCOCl}$, triethylamine, $\mathrm{CH}_{2} \mathrm{Cl}_{2}$, reflux, $5 \mathrm{~h} \mathrm{(11a-o,} \mathrm{17-63 \% ;} \mathrm{13a-c,} \mathrm{18-47 \% ;} \mathrm{15a-b,} \mathrm{7-13 \% );}$ (c) TBAF, dry $\mathrm{THF}, 0^{\circ} \mathrm{C}, 30 \mathrm{~min}(28-34 \%)$.

The additional 3-chloro- $\beta$-lactam products $\mathbf{1 2 a - 1 2 c , 1 4 a}$ and $\mathbf{1 4 b}$ were also obtained in a similar Staudinger reaction of the appropriate imines $\mathbf{9 t}-\mathbf{9 v}, \mathbf{9} \mathbf{w}$ and $\mathbf{9 x}$ with chloroacetyl chloride. The coupling constant for H-3 and H-4 of the azetidinone ring is generally useful in the identification of the stereochemistry of 2-azetidinones, with $J_{3,4}$ usually of 4-6 Hz for the cis and $J_{3,4} 1-2 \mathrm{~Hz}$ for the trans stereoisomers. The structural assignment 
of 3-monochloro $\beta$-lactam 10n was particularly interesting for the assignments of $\mathrm{H}-3$ and $\mathrm{H}-4$ protons of the $\beta$-lactam compound. Two doublet signals were observed in the ${ }^{1} \mathrm{H}$ NMR spectrum for H-4 and H-3 at $\delta 4.61$ and 4.89 ppm, respectively $\left(J_{3,4}=1.52 \mathrm{~Hz}\right)$, which confirmed the trans isomer assignment) and were more downfield due to the adjacent electron withdrawing chlorine substituent. In the ${ }^{13} \mathrm{C}$ NMR spectrum of 10n, the corresponding C3 and $C 4$ carbons of $\beta$-lactam appeared at $62.67\left(C_{3}\right)$ and $65.63\left(C_{4}\right)$ ppm, respectively, with the characteristic signal of carbonyl group of the $\beta$-lactam at $\delta 160.22 \mathrm{ppm}$. The compounds were isolated exclusively as the trans isomer; the only exception was compound 10e, where both the trans and cis compounds were obtained (trans:cis ratio 1.9:1; $J_{3,4}=5.00 \mathrm{~Hz}$ cis, $J_{3,4}=2 \mathrm{~Hz}$ trans).

Single crystal X-ray analysis was obtained for compounds $10 \mathbf{e}$ and 100 (recrystallised from dichloromethane/n-hexane), and the crystal structure is shown in Figure 3. The crystal data and structure refinement for the 3-chloro compounds $10 \mathbf{e}$ and $\mathbf{1 0 0}$ are displayed in Tables 1 and 2. The trans stereochemistry for compounds 10e and 10o was confirmed from the X-ray crystal structures. The aryl rings at N-1 (Ring A) and C-4 are in a non-coplanar cis-like arrangement, while the phenyl ring at $\mathrm{C} 4$ (Ring $\mathrm{B}$ ) and the 3-chloro substituent are in a trans configuration on opposite sides of the $\beta$-lactam ring. For compound $\mathbf{1 0 e}$, the distance between the centroid of ring $\mathrm{A}$ and ring $\mathrm{B}$ is $\sim 5.2 \AA$, while the distance between ring $\mathrm{B}$ and the chloro group is $\sim 5.0 \AA$. For compounds $\mathbf{1 0 e}$ and 10o, the torsional angle value ring $B / C$ was calculated as $116.0(1)^{\circ}$ and $112.0(3)^{\circ}$, respectively, which is consistent with the small trans coupling constant observed in the ${ }^{1} \mathrm{H}$ NMR spectrum of 2.00 and $2.20 \mathrm{~Hz}$, respectively, for $\mathrm{H} 3 / \mathrm{H} 4$ in these compounds. The $\beta$-lactam $\mathrm{C}=\mathrm{O}$ bond lengths are 1.2122(18) $\AA$ and 1.2122(19) $\AA$ for compounds 10e and 10o, respectively, which is consistent with the data previously reported for the carbonyl bond length of monocyclic $\beta$-lactams of 1.217(3) $\AA$ [69] and 1.207(2) $\AA$ [70]. The torsional angles (Ring A/B) observed for compounds 10e and 10o were calculated to be $60.7(2)^{\circ}$ and $62.7(2)^{\circ}$, respectively; these values are slightly greater than the corresponding torsional angles for Ring $\mathrm{A} / \mathrm{B}$ of $55^{\circ}$ and $53^{\circ}$ reported in DAMAcolchicine and CA-4, respectively $[6,71]$. The numbers in parentheses refer to the second crystallographically independent molecule in the asymmetric unit.

Table 2. X-ray Crystallographic Data for $\beta$-lactams 10e, 10o, 11o and 16g.

\begin{tabular}{|c|c|c|c|c|c|c|c|c|}
\hline Compound & $\mathrm{O}^{\mathrm{R}^{1}}$ & $\begin{array}{c}\text { Ring Plane } \\
\text { Normal } \\
\text { AB Angle } \\
\left.{ }^{\circ}{ }^{\circ}\right)\end{array}$ & $\begin{array}{c}\text { Ring Plane } \\
\text { Normal } \\
\text { BC Angle } \\
\left.{ }^{\circ}{ }^{\circ}\right)\end{array}$ & $\begin{array}{c}\text { Ring Plane } \\
\text { Normal } \\
\text { AC Angle } \\
\left.{ }^{\circ}{ }^{\circ}\right)\end{array}$ & $\begin{array}{l}\text { Ring A to } \\
\text { Central } \\
\text { Torsion } \\
\left(^{\circ}\right)^{a}\end{array}$ & $\begin{array}{l}\text { Ring B to } \\
\text { Central } \\
\text { Torsion } \\
\left({ }^{\circ}\right)^{b}\end{array}$ & $\begin{array}{c}\text { Ring AB } \\
\text { Torsion } \\
\left({ }^{\circ}\right)^{c}\end{array}$ & $\begin{array}{c}\text { Ring BC } \\
\text { Torsion } \\
\left({ }^{\circ}\right)^{d}\end{array}$ \\
\hline $10 \mathrm{e}$ & $\mathrm{R}^{1}=\mathrm{Cl}, \mathrm{R}^{3}=\mathrm{R}^{3}=\mathrm{H}$ & $81.20(5)$ & $71.33(6)$ & $20.68(6)$ & $-24.7(2)$ & $168.6(1)$ & $-60.7(2)$ & $116.0(1)$ \\
\hline $10 \mathrm{o}$ & $\mathrm{R}^{1}=\mathrm{R}^{3}=\mathrm{Cl}, \mathrm{R}^{2}=\mathrm{H}$ & $91.49(5)$ & $80.74(7)$ & $159.88(6)$ & $27.8(2)$ & $-156.7(1)$ & $62.7(2)$ & $-112.0(3)$ \\
\hline 110 & $\mathrm{R}^{1}=\mathrm{R}^{2}=\mathrm{Cl}, \mathrm{R}^{3}=\mathrm{CH}_{3}$ & $91.7(1)$ & 103.7(1) & $17.3(1)$ & $-15.3(4)$ & $160.6(4)$ & $-68.9(4)$ & $139.5(3)$ \\
\hline $16 \mathrm{~g}$ & $\mathrm{R}^{1}=\mathrm{Br}, \mathrm{R}^{2}=\mathrm{H}, \mathrm{R}^{3}=\mathrm{Cl}$ & $91.49(5)$ & $80.74(7)$ & $159.88(6)$ & $27.8(2)$ & $-156.7(1)$ & $62.7(2)$ & $-110.3(4)$ \\
\hline
\end{tabular}

${ }^{a}$ C18-C13-N1-C2, C18-C13-N1-C2, C22-C17-N1-C2, C18-C13-N1-C2; ${ }^{b}$ C10-C5-C4-N1, C10-C5-C4-N1, C10-C5-C4-N1, C10-C5-C4-N1;

${ }^{c}$ C13-N1-C4-C5, C13-N1-C4-C5, C12-N1-C4-C5, C13-N1-C4-C5; ${ }^{d}$ C5-C4-C3-Cl1, C5-C4-C3-Cl1, C5-C4-C3-Cl1, C5-C4-C3-Br1 for 10e, 10o, 110 and $16 \mathrm{~g}$, respectively. 

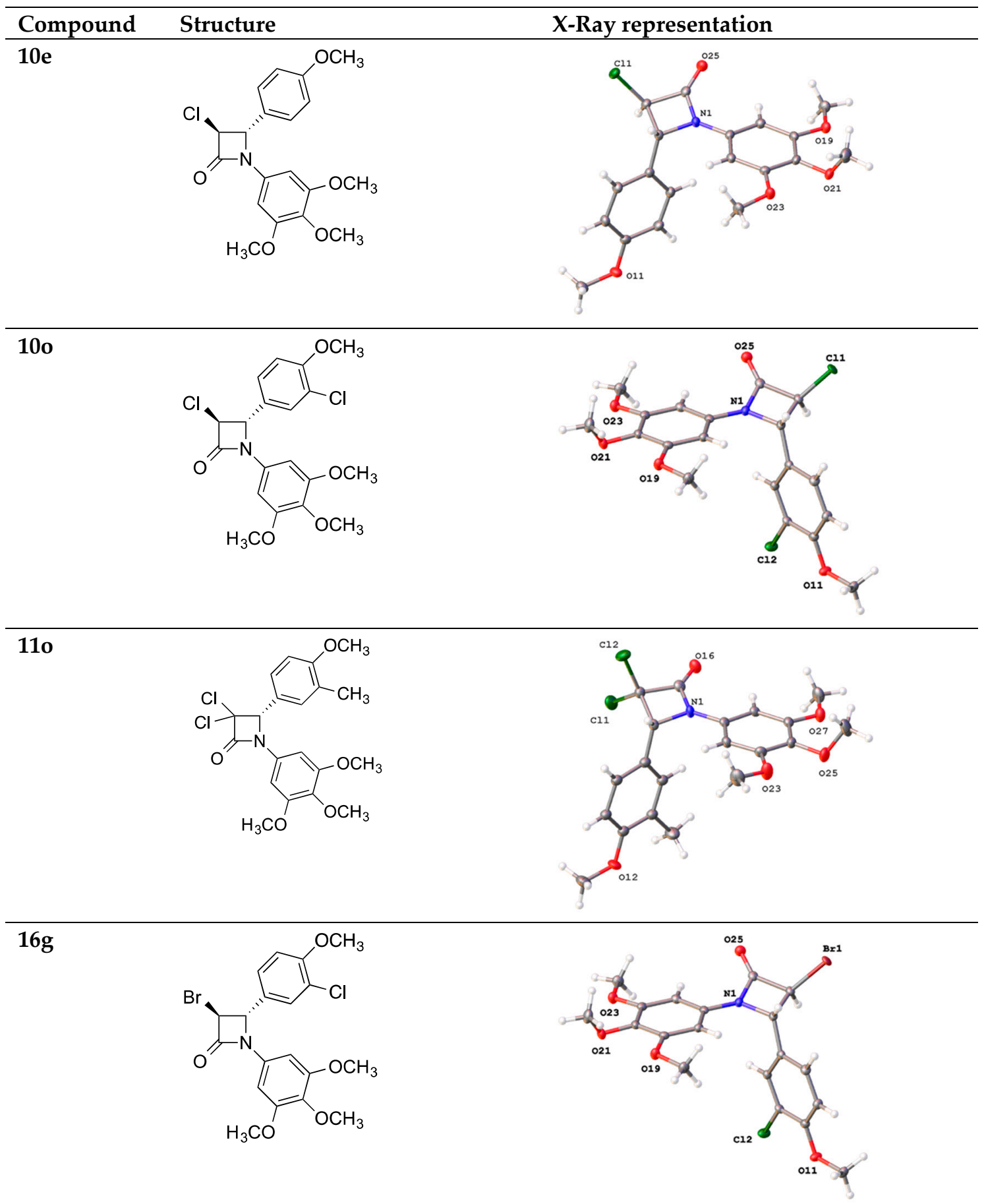

Figure 3. ORTEP representation of the X-ray crystal structure of compounds 10e, 10o, 11o and $\mathbf{1 6 g}$ with heteroatoms labelled and thermal ellipsoids set at 50\% probability. Structure 110 shows the majority occupied disordered 4-methoxyphenyl moiety ( $81 \%$ occupied). For structures $\mathbf{1 0 o}$ and $\mathbf{1 6 g}$, the 3 position is substituted by both chloride (75\%) and bromide ( $25 \%$ ); distances restrained, and atomic displacement constrained.

As an extension to this study, a further series of 3,3-dichloro- $\beta$-lactams (11a-11o, 13a-c, 15a, 15b) with similar substituents in rings $A$ and $B$ as that described for the 3-chloro $\beta$-lactams was prepared (Scheme 2). The phenolic product 11n was obtained by treating the silyl ether 111 with TBAF. The compounds were obtained in moderate yields (27-63\%), apart from compounds $\mathbf{1 5 a}$ and $\mathbf{1 5 b}$ (with 3,5-dimethoxy substitution pattern in the aryl A ring), which were isolated in low yields, 13 and $7 \%$, respectively. When comparing the 3,3 -dichloro- $\beta$-lactams with the mono chloro $\beta$-lactam compounds, the ${ }^{1} \mathrm{H}$ NMR spectrum 
for the 3,3-dichloro $\beta$-lactam compound $11 \mathrm{n}$ is relatively simple; the characteristic signal for 3,3 -dichloro $\beta$-lactam compounds appeared as a singlet for the H4 proton at $\delta 5.39 \mathrm{ppm}$ and it is further downfield than in the corresponding $10 \mathrm{n}$ because of the electron withdrawing properties of the two chlorine atoms. In the ${ }^{13} \mathrm{C}$ NMR spectrum, the high resonance signals at $\delta 83.68$ and $73.54 \mathrm{ppm}$ were assigned to $\mathrm{C} 3$ (with the dichloro substituent) and C4, respectively, while the resonances for $C 3$ and $C 4$ were observed at $62.67\left(C_{3}\right)$ and $65.63\left(C_{4}\right)$ $\mathrm{ppm}$ in the 3-monochloro compound 10n. The X-ray crystal structure and data for the 3,3-dichloro $\beta$-lactam compound $\mathbf{1 1 o}$ are presented in Figure 3 and Table 1 and show that rings $\mathrm{A}$ and $\mathrm{B}$ (located at $\mathrm{N}-1$ and $\mathrm{C}-4$ of the $\beta$-lactam ring) are not coplanar, with a torsional angle of $68.9^{\circ}$ (see Table 2). A significant difference in the distances from the centroid of ring B to each of the two C 3 chloro substituents ( $3.7 \AA$ and $5.4 \AA$ ) was observed. This may be relevant in rationalising the differences in the antiproliferative activity observed for the monochloro and dichloro- $\beta$-lactam compounds.

As the 3-chloro- $\beta$-lactams exhibited an excellent antiproliferative profile, a further series of related 3-bromo $\beta$-lactams was investigated by using the Staudinger procedure with bromoacetyl chloride (Scheme 3). The preparation of 3-bromo $\beta$-lactams using bromoacetyl bromide [72], bromination of 3-azetidinone [48] and a ring expansion of aziridines with triphenylphosphine/NBS or triphenylphosphine dibromide has been reported [73]. The 3-bromo $\beta$-lactams (16a-16i) were initially obtained as a mixture with corresponding 3 -chloro- $\beta$-lactams in a ratio of $1: 2$ in most cases in yields of $5-31 \%$, due to the halogen exchange with the chlorinated solvent (dichloromethane), following purification by either recrystallisation or from the gradient column chromatography. The presence of the trans isomer of 3-bromo- $\beta$-lactam 16a was confirmed from the ${ }^{1} \mathrm{H}$ NMR spectrum that shows $\mathrm{H}-3$ at $\delta 5.05$ and $\mathrm{H}-4$ at $\delta 4.65(\mathrm{~J} 1.96 \mathrm{~Hz}$ ) (in comparison, $\mathrm{H}-3$ and $\mathrm{H}-4$ of the 3-chloro $\beta$-lactam 10e were observed at $\delta 4.95$ and $\delta 4.63, J 2.00 \mathrm{~Hz}$ ). The phenolic product $\mathbf{1 6 j}$ was obtained by treating the silyl ether $\mathbf{1 9} \mathbf{i}$ with TBAF. The asymmetric synthesis of $\mathbf{1 6} \mathbf{j}(3 S, 4 S)$ was previously reported [48]. The $\mathrm{X}$-ray crystal structure and data for the 3-bromo- $\beta$-lactam compound 16g (Figure 3, Table 1) again demonstrates that rings A and B (located at N-1 and C-4 of the $\beta$-lactam ring) are not coplanar (see Table 2) with Ring A/B having a torsional angle of $62.7(2)^{\circ}$, and Ring $B / C\left(\beta\right.$-lactam) having a torsional angle value of $110.3^{\circ}$.<smiles>[R]c1ccc(/C=N/c2cc(OC)c(OC)c(OC)c2)cc1[R]</smiles>

$9 e, 9 f, 9 m-r$ (a)<smiles>[R]c1ccc([C@H]2C(Br)C(=O)N2c2cc(OC)c(OC)c(OC)c2)cc1[R]</smiles>

16a: $\mathrm{R}^{1}=\mathrm{OCH}_{3}, \mathrm{R}^{2}=\mathrm{H}$

16b: $\mathrm{R}^{1}=\mathrm{OCH}_{2} \mathrm{CH}_{3}, \mathrm{R}^{2}=\mathrm{H}$

16c: $R^{1}=\mathrm{SCH}_{3}, \mathrm{R}^{2}=\mathrm{H}$

16d: $R^{1}=\mathrm{SCH}_{2} \mathrm{CH}_{3}, \mathrm{R}^{2}=\mathrm{H}$

16e: $\mathrm{R}^{1}=\mathrm{OCH}_{3}, \mathrm{R}^{2}=\mathrm{CH}_{3}$

16f: $\mathrm{R}^{1}=\mathrm{OCH}_{3}, \mathrm{R}^{2}=\mathrm{F}$

16g: $\mathrm{R}^{1}=\mathrm{OCH}_{3}, \mathrm{R}^{2}=\mathrm{Cl}$

16h: $\mathrm{R}^{1}=\mathrm{OCH}_{3}, \mathrm{R}^{2}=\mathrm{Br}$

(b)

16i: $\mathrm{R}^{1}=\mathrm{OCH}_{3}, \mathrm{R}^{2}=\mathrm{OTBDMS}$

16j: $\mathrm{R}^{1}=\mathrm{OCH}_{3}, \mathrm{R}^{2}=\mathrm{OH}$

Scheme 3. Synthesis of $\beta$-lactams 16a-i. Reagents and conditions: (a) $\mathrm{BrCH}_{2} \mathrm{COCl}$, toluene, reflux, $5 \mathrm{~h}(5-31 \%) ;(\mathbf{b}) \mathrm{TBAF}, \operatorname{dry} \mathrm{THF}, 0{ }^{\circ} \mathrm{C}, 30 \mathrm{~min}(32 \%)$. 
To improve the solubility and bioavailability of the compounds, the phenol 11n was selected for phosphate ester prodrug preparation. The esterification of the phenol 11n with dibenzyl phosphite using diisopropylethylamine and dimethylaminopyridine afforded dibenzyl phosphate $\beta$-lactam ester 17 (Scheme 4). The subsequent hydrogenation of 17 with a palladium/carbon catalyst removed the dibenzyl protecting groups to afford the phosphate ester 18 in a 75\% yield, while the $\beta$-lactam ring remained intact.<smiles>COc1ccc([C@@H]2[C@H](Cl)C(=O)N2c2cc(OC)c(OC)c(OC)c2)cc1O</smiles><smiles>COc1ccc(OP(=O)(O)Oc2cc([C@@H]3N(c4cc(OC)c(OC)c(OC)c4)C(=O)[C@]3(Cl)c3ccccc3)ccc2OC)cc1OP(=O)(O)Cc1ccccc1</smiles>

Scheme 4. Synthesis of phosphate prodrug 18. Reagents and conditions: (a) dibenzyl phosphate, DIPEA, DMAP, $\mathrm{CCl}_{4}, \mathrm{CH}_{3} \mathrm{CN},-10-20{ }^{\circ} \mathrm{C}$, 3h. (66\%); (b) $\mathrm{H}_{2} / \mathrm{Pd} / \mathrm{C}$, ethanol-ethyl acetate, 1:1, $3 \mathrm{~h}$, $20{ }^{\circ} \mathrm{C}(75 \%)$.

HPLC stability studies at three different $\mathrm{pH}$ systems were performed on a representative compound 16a to determine the stability at acidic $\mathrm{pH} 4, \mathrm{pH} 7.4$ and basic $\mathrm{pH} 9$ (acid $\mathrm{pH}$ found in the stomach, basic found in the intestine and $\mathrm{pH} 7.4$ in the plasma). The compound was stable at these buffered $\mathrm{pH}$ systems with a half-life of $18 \mathrm{~h}(\mathrm{pH} 4), 20 \mathrm{~h}$ (pH 9) and $22 \mathrm{~h}(\mathrm{pH} 7.4)$.

\subsection{Biochemical Results}

\subsubsection{Activity of $\beta$-Lactam Compounds in MCF-7 Human Breast Cancer Cell Line}

The antiproliferative potential of the $\beta$-lactams 10a-o, 11a-o, 12a-c, 13a-c, 18, 14a, 14b, 15a, $15 b$ and $16 a-h$ was initially evaluated in the CA-4 sensitive oestrogen receptor positive MCF-7 human breast cancer cell line. CA-4 was used as the control compound in the assay (Table 3), together with $\beta$-lactam compounds that we had previously reported $[34,74]$. The $\mathrm{IC}_{50}$ value obtained for CA-4 $(0.0039 \mu \mathrm{M}$ for MCF-7) is in good agreement with reported values [75]. The introduction of the halogen substituent at C-3 was examined in an effort to investigate the effect on the activity of this substituent, and subsequently optimising the cytotoxic effects against MCF-7 human breast cancer cells. The most potent analogues in MCF-7 cells were further screened in the MDA-MB-231, Hs578T and Hs578Ts(i)8 triple negative breast cancer cell lines, multiple myeloma (U266), acute myeloid leukaemia (HL60) and colon cancer (HT-29 and SW480) cell lines using the AlamarBlue assay. Compounds were initially assessed for antiproliferative activity in MCF-7 cells to determine the structure-activity relationship for these halogenated compounds and to identify the most potent compounds to progress for further investigation. 
Table 3. Antiproliferative activity of $\beta$-lactam compounds 10a-o, 11a-o, 12a-c, 13a-c, 14a, 14b, 15a, 15b, 16a-j, 18 and CA-4 in MCF-7 cells.

\begin{tabular}{|c|c|c|c|c|}
\hline Compound ${ }^{a}$ & Compound Number & & $\begin{array}{c}\mathrm{IC}_{50}, \mu \mathrm{M} \\
(\mathrm{MCF}-7,72 \mathrm{~h}) \\
\text { b,f }\end{array}$ & $\log P$ \\
\hline \multirow{15}{*}{ ${ }_{\mathrm{OCH}_{3}}^{\mathrm{OCH}_{3}}$} & $10 \mathrm{a}$ & $\mathrm{R}^{1}=\mathrm{R}^{2}=\mathrm{R}^{3}=\mathrm{H}$ & $23.450 \pm 2.80$ & 3.48 \\
\hline & $10 \mathrm{~b}$ & $\mathrm{R}^{1}=\mathrm{Cl}, \mathrm{R}^{2}=\mathrm{R}^{3}=\mathrm{H}$ & $1.298 \pm 0.17$ & 4.20 \\
\hline & $10 \mathrm{c}$ & $\mathrm{R}^{1}=\mathrm{Br}, \mathrm{R}^{2}=\mathrm{R}^{3}=\mathrm{H}$ & $0.506 \pm 0.11$ & 4.35 \\
\hline & $10 \mathrm{~d}$ & $\mathrm{R}^{1}=\mathrm{NO}_{2 .} \mathrm{R}^{2}=\mathrm{R}^{3}=\mathrm{H}$ & $4.366 \pm 0.61$ & 3.23 \\
\hline & $10 \mathrm{e}$ cis & $\mathrm{R}^{1}=\mathrm{OCH}_{3}, \mathrm{R}^{2}=\mathrm{R}^{3}=\mathrm{H}($ cis $)$ & $0.317 \pm 0.04$ & 3.40 \\
\hline & 10e trans $^{g}$ & $\mathrm{R}^{1}=\mathrm{OCH}_{3}, \mathrm{R}^{2}=\mathrm{R}^{3}=\mathrm{H}($ trans $)$ & $0.034 \pm 0.004$ & 3.40 \\
\hline & $10 f^{g}$ & $\mathrm{R}^{1}=\mathrm{OCH}_{2} \mathrm{CH}_{3}, \mathrm{R}^{2}=\mathrm{R}^{3}=\mathrm{H}$ & $0.130 \pm 0.017$ & 3.93 \\
\hline & $10 \mathrm{~g}$ & $\mathrm{R}^{1}=\mathrm{OC}_{6} \mathrm{H}_{5}, \mathrm{R}^{2}=\mathrm{R}^{3}=\mathrm{H}$ & $64.070 \pm 7.30$ & 5.58 \\
\hline & $10 \mathrm{~h}$ & $\mathrm{R}^{1}=\mathrm{OCH}_{2} \mathrm{C}_{6} \mathrm{H}_{5}, \mathrm{R}^{2}=\mathrm{R}^{3}=\mathrm{H}$ & $59.910 \pm 6.99$ & 5.17 \\
\hline & $10 \mathrm{i}^{\mathrm{g}}$ & $\mathrm{R}^{1}=\mathrm{SCH}_{3}, \mathrm{R}^{2}=\mathrm{R}^{3}=\mathrm{H}$ & $0.073 \pm 0.004$ & 4.04 \\
\hline & $10 \mathrm{j}$ & $\mathrm{R}^{2} \mathrm{R}^{3}=\mathrm{CH}=\mathrm{CH}-\mathrm{CH}=\mathrm{CH}, \mathrm{R}^{1}=\mathrm{H}$ & $14.660 \pm 2.26$ & 4.66 \\
\hline & 10k & $\mathrm{R}^{1} \mathrm{R}^{2}=\mathrm{CH}=\mathrm{CH}-\mathrm{CH}=\mathrm{CH}, \mathrm{R}^{3}=\mathrm{H}$ & $0.202 \pm 0.015$ & 4.66 \\
\hline & $10 \mathrm{~m}$ & $\mathrm{R}^{1}=\mathrm{OCH}_{3}, \mathrm{R}^{2}=\mathrm{NO}_{2}, \mathrm{R}^{3}=\mathrm{H}$ & $3.088 \pm 0.41$ & 3.17 \\
\hline & $10 \mathrm{n}$ & $\mathrm{R}^{1}=\mathrm{OCH}_{3}, \mathrm{R}^{2}=\mathrm{OH}, \mathrm{R}^{3}=\mathrm{H}$ & $0.0175 \pm 0.009$ & 2.67 \\
\hline & $10 o^{h}$ & $\mathrm{R}^{1}=\mathrm{OCH}_{3}, \mathrm{R}^{2}=\mathrm{Cl}, \mathrm{R}^{3}=\mathrm{H}$ & $0.433 \pm 0.050$ & 4.03 \\
\hline \multirow{15}{*}{ (l) } & $11 \mathrm{a}$ & $\mathrm{R}^{1}=\mathrm{R}^{2}=\mathrm{R}^{3}=\mathrm{H}$ & $37.220 \pm 3.21$ & 4.67 \\
\hline & $11 b$ & $\mathrm{R}^{1}=\mathrm{Cl}, \mathrm{R}^{2}=\mathrm{R}^{3}=\mathrm{H}$ & $12.830 \pm 1.08$ & 5.38 \\
\hline & 11c & $\mathrm{R}^{1}=\mathrm{Br}, \mathrm{R}^{2}=\mathrm{R}^{3}=\mathrm{H}$ & $18.160 \pm 1.83$ & 5.53 \\
\hline & 11d & $\mathrm{R}^{1}=\mathrm{NO}_{2}, \mathrm{R}^{2}=\mathrm{R}^{3}=\mathrm{H}$ & $61.640 \pm 7.61$ & 4.41 \\
\hline & $11 e^{g}$ & $\mathrm{R}^{1}=\mathrm{OCH}_{3}, \mathrm{R}^{2}=\mathrm{R}^{3}=\mathrm{H}$ & $0.119 \pm 0.012$ & 4.59 \\
\hline & $11 f^{g}$ & $\mathrm{R}^{1}=\mathrm{OCH}_{2} \mathrm{CH}_{3}, \mathrm{R}^{2}=\mathrm{R}^{3}=\mathrm{H}$ & $0.164 \pm 0.015$ & 5.11 \\
\hline & $11 \mathrm{~g}$ & $\mathrm{R}^{1}=\mathrm{OC}_{6} \mathrm{H}_{5}, \mathrm{R}^{2}=\mathrm{R}^{3}=\mathrm{H}$ & $62.310 \pm 10.2$ & 6.77 \\
\hline & $11 \mathrm{~h}$ & $\mathrm{R}^{1}=\mathrm{OCH}_{2} \mathrm{C}_{6} \mathrm{H}_{5}, \mathrm{R}^{2}=\mathrm{R}^{3}=\mathrm{H}$ & $36.340 \pm 3.68$ & 6.35 \\
\hline & $11 \mathrm{i}^{\mathrm{g}}$ & $\mathrm{R}^{1}=\mathrm{SCH}_{3}, \mathrm{R}^{2}=\mathrm{R}^{3}=\mathrm{H}$ & $0.291 \pm 0.030$ & 5.23 \\
\hline & $11 \mathrm{j}$ & $\mathrm{R}^{2} \mathrm{R}^{3}=\mathrm{CH}=\mathrm{CH}-\mathrm{CH}=\mathrm{CH}, \mathrm{R}^{1}=\mathrm{H}$ & $7.990 \pm 0.70$ & 5.84 \\
\hline & $11 k$ & $\mathrm{R}^{1} \mathrm{R}^{2}=\mathrm{CH}=\mathrm{CH}-\mathrm{CH}=\mathrm{CH}, \mathrm{R}^{3}=\mathrm{H}$ & $0.322 \pm 0.04$ & 5.84 \\
\hline & $11 \mathrm{~m}$ & $\mathrm{R}^{1}=\mathrm{OCH}_{3}, \mathrm{R}^{2}=\mathrm{NO}_{2}, \mathrm{R}^{3}=\mathrm{H}$ & $0.353 \pm 0.04$ & 4.35 \\
\hline & $11 n$ & $\mathrm{R}^{1}=\mathrm{OCH}_{3}, \mathrm{R}^{2}=\mathrm{OH}, \mathrm{R}^{3}=\mathrm{H}$ & $0.031 \pm 0.004$ & 3.85 \\
\hline & $110^{h}$ & $\mathrm{R}^{1}=\mathrm{OCH}_{3}, \mathrm{R}^{2}=\mathrm{CH}_{3}, \mathrm{R}^{3}=\mathrm{H}$ & $0.747 \pm 0.060$ & 5.09 \\
\hline & 18 & $\mathrm{R}^{1}=\mathrm{OCH}_{3}, \mathrm{R}^{2}=\mathrm{OP}(\mathrm{O})(\mathrm{OH})_{2}, \mathrm{R}^{3}=\mathrm{H}$ & $0.077 \pm 0.01$ & 2.80 \\
\hline \multirow{3}{*}{$\mathrm{OCH}_{3}^{\mathrm{H}_{3} \mathrm{CO}}$} & $12 \mathrm{a}$ & $\mathrm{R}^{1}=\mathrm{OCH}_{3}$ & $14.810 \pm 1.58$ & 3.40 \\
\hline & $12 b$ & $\mathrm{R}^{1}=\mathrm{OCH}_{2} \mathrm{CH}_{3}$ & $25 \%(10 \mu \mathrm{M})^{c}$ & 3.93 \\
\hline & $12 c$ & $\mathrm{R}^{1}=\mathrm{SCH}_{3}$ & $10 \%(10 \mu \mathrm{M})^{c}$ & 4.04 \\
\hline
\end{tabular}


Table 3. Cont.
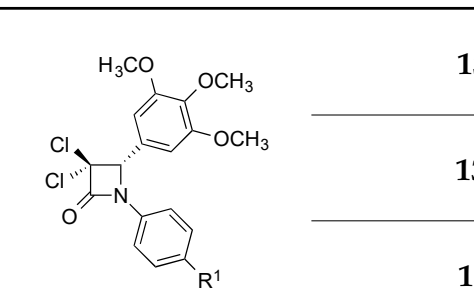

$13 a$

$\mathrm{R}^{1}=\mathrm{OCH}_{3}$

$45.9 \pm 6.73$

4.59

$13 b$

$\mathrm{R}^{1}=\mathrm{OCH}_{2} \mathrm{CH}_{3}$,

$40 \%(10 \mu \mathrm{M})^{\mathrm{c}}$

5.11

$13 c$

$\mathrm{R}^{1}=\mathrm{SCH}_{3}$

$20 \%(10 \mu \mathrm{M})^{\mathrm{c}}$

5.23<smiles>[R]c1ccc([C@H]2[C@H](Cl)C(=O)N2c2cc(OC)cc(OC)c2)cc1</smiles>

$14 a$

$\mathrm{R}^{1}=\mathrm{OCH}_{3}$

$0.680 \pm 0.160$

4.11

$14 b$

$\mathrm{R}^{1}=\mathrm{OCH}_{2} \mathrm{CH}_{3}$

$0.045 \pm 0.01$

4.64

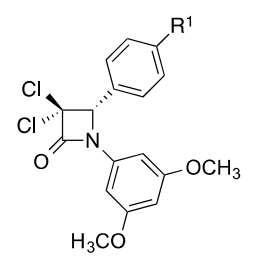

$15 a$

$\mathrm{R}^{1}=\mathrm{OCH}_{3}$

$6.612 \pm 2.00$

5.29

$\begin{array}{lll}\mathrm{R}^{1}=\mathrm{OCH}_{2} \mathrm{CH}_{3} & 0.273 \pm 0.010^{\mathrm{i}} & 5.82\end{array}$

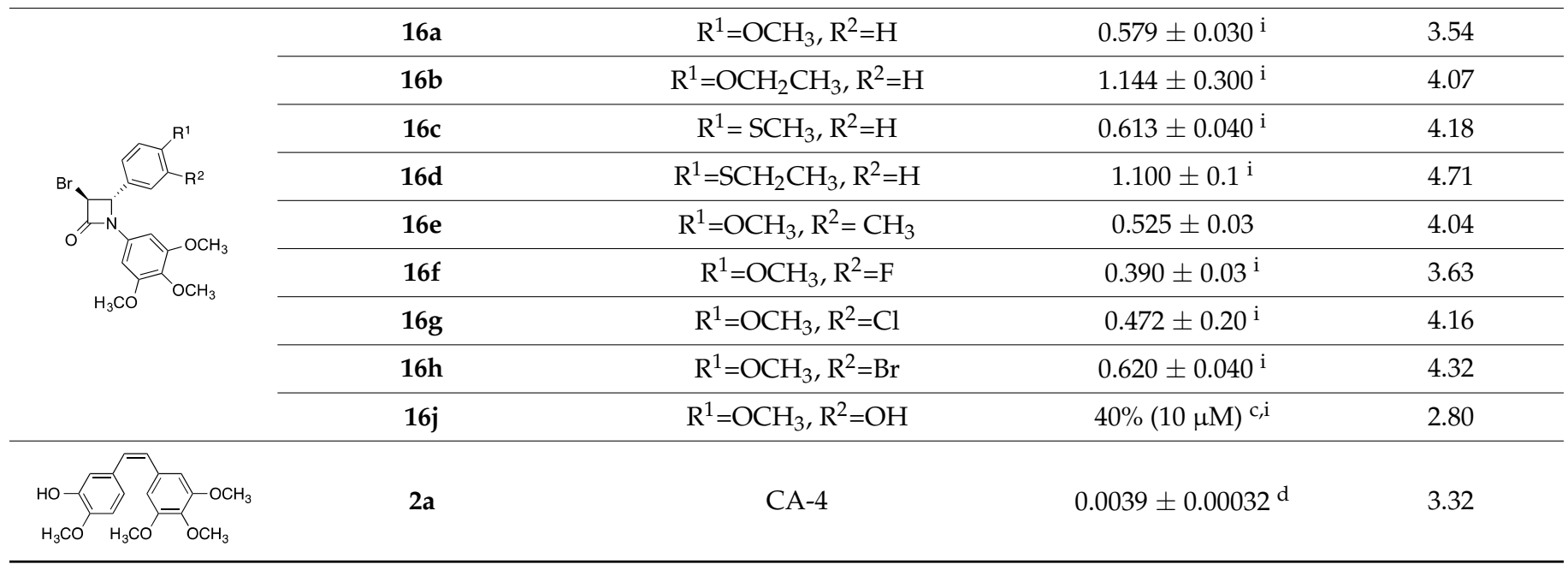

a 3-Chloro and 3-bromo- $\beta$-lactam compounds are trans isomers except where specifically indicated. One enantiomer only is shown.

${ }^{\mathrm{b}} \mathrm{IC}_{50}$ values are half maximal inhibitory concentrations required to block the growth stimulation of MCF-7 cells. Values represent the mean \pm SEM (error values $\times 10^{-6}$ ) for at least three experiments performed in triplicate. ${ }^{\mathrm{C}} \mathrm{IC}_{50}$ values were not calculated; the percentage shown is the inhibition of cell viability at a concentration of $10 \mu \mathrm{M}$ unless otherwise indicated. ${ }^{\mathrm{d}}$ The $\mathrm{IC}_{50}$ value obtained for CA-4 $\left(0.0039 \mu \mathrm{M}\right.$ for MCF-7) is in good agreement with the reported values, Ref 74. ${ }^{\mathrm{e}}$ clogP values calculated from ChemBioDraw 13.0. ${ }^{\mathrm{f}}$ Lactate Dehydrogenase assay: \% cell lysis at compound concentration of $10 \mu \mathrm{M}$ following treatment of the cells, 3a (12\%), 10e (5\%), 10j (4\%), 10i $(3 \%), 10$ n $(17 \%), 11$ e $(10 \%)$ and 11n $(8 \%)$ using LDH assay kit from Promega, Ref 104. ${ }^{g}$ Ref $75 .{ }^{\text {h }}$ Ref $34 .{ }^{\text {i }}$ SW480 Cell viability: 16a $(52 \%), 16 \mathrm{~b}(50 \%), 16 \mathrm{c}(32 \%), \mathbf{1 6 d}(22 \%), \mathbf{1 6 e}(40 \%), \mathbf{1 6 f}(42 \%), \mathbf{1 6 g}(38 \%), \mathbf{1 6 h}(26 \%)$ and $\mathbf{1 6 j}(48 \%)$; percentage shown is the inhibition of cell viability at a concentration of $10 \mu \mathrm{M}$.

In the series of compounds with 3-chloro substituent $\mathbf{1 0 a}-\mathbf{o}$, a number of varied substituents were introduced at C-4 of Ring B, while retaining the 3,4,5-trimethoxy substitution for Ring A usually present in many colchicine binding-site type ligands [19]. The introduction of nitro (10d), chloro (10b) and bromo (10c) at C-4 of Ring B resulted in increased activity when compared with the unsubstituted 10a, with the 4-methoxy 10e and 4-thiomethyl 10i showing excellent potency ( $\mathrm{IC}_{50} 34$ and $73 \mathrm{nM}$, respectively [74]). The cis isomer of $\mathbf{1 0 e}$ demonstrated a nine-fold reduction in activity $\left(\mathrm{IC}_{50} 0.317 \mu \mathrm{M}\right)$ when 
compared with the trans isomer $\left(\mathrm{IC}_{50} 34 \mathrm{nM}\right)$. The bulkier 4-phenoxy $\mathbf{1 0 g}$ and 4-benzyloxy 10h substituents resulted in significantly reduced activity $\left(\mathrm{IC}_{50} 64.07\right.$ and $59.91 \mu \mathrm{M}$, respectively). Interestingly, the 2-naphthyl 10k was much more potent $\left(\mathrm{IC}_{50} 0.20 \mu \mathrm{M}\right)$ than the 1-naphthyl compound $10 \mathrm{j}\left(\mathrm{IC}_{50} 14.66 \mu \mathrm{M}\right)$, possibly due to the steric interference by the 1-naphthyl at the colchicine binding site, while the 2-naphthyl was more easily accommodated. Compounds $10 \mathrm{~m}$ and $\mathbf{1 0 0}$, with an additional substituent at the meta position of $\mathrm{B}$ ring (10m nitro and $10 \mathrm{o}$ chloro), retained moderate activity with $\mathrm{IC}_{50}$ values of 3.088 and $0.433 \mu \mathrm{M}$, respectively.

The most potent compound in this series was identified as $\mathbf{1 0}$, with the characteristic CA-4 3-hydroxy-4-methoxyphenyl Ring B substitution $\left(\mathrm{IC}_{50}=0.017 \mu \mathrm{M}\right)$, which compares favourably with CA-4 $\left(\mathrm{IC}_{50} 0.004 \mu \mathrm{M}\right)$. Analysis of the results from the 3,3-dichloro compound series 11a-n showed that the compounds displayed a similar SAR profile to the 3-chloro compounds but with reduced potency, with compounds $11 \mathrm{e}, \mathbf{1 1 f}, \mathbf{1 1 i}, \mathbf{1 1 k}$ and $11 \mathrm{~m}$ displaying $\mathrm{IC}_{50}$ values in the range $0.119-0.353 \mu \mathrm{M}$. The most potent compound in this series was identified as 11n, again with the characteristic CA-4 3-hydroxy-4-methoxyphenyl Ring B substitution $\left(\mathrm{IC}_{50}=0.031 \mu \mathrm{M}\right)$. Interestingly, the prodrug 18 (the phosphate ester of the phenol 11n) retained potent activity with $\mathrm{IC}_{50}=0.077 \mu \mathrm{M}$. The introduction of the 3,4,5-trimethoxyaryl ring $\mathrm{A}$ at $\mathrm{C}-4$ of the $\beta$-lactam in both the 3-chloro and 3,3-dichloro series (compounds 12a-c, 13a-c) resulted in significant decrease in activity, e.g., compound 10e $\left(\mathrm{IC}_{50}=0.034 \mu \mathrm{M}\right.$ (trans) and $0.317 \mu \mathrm{M}($ cis $\left.)\right)$ compared with $12 \mathrm{a}\left(\mathrm{IC}_{50}=14.81 \mu \mathrm{M}\right)$. The poor activity of compounds $\mathbf{1 2} \mathbf{a}-\mathbf{c}$ and $13 \mathbf{a}-\mathbf{c}$ where the 3,4,5-trimethoxyphenyl group A is located at C-4 could be due to the bulkiness of Ring A, which is unable to fit correctly in the target binding pocket of tubulin, in agreement with previous reports findings [33].

In compounds $\mathbf{1 4 a}, \mathbf{1 4 b}, \mathbf{1 5} \mathbf{a}$ and $\mathbf{1 5} \mathbf{b}$, the 3,5-dimethoxyaryl ring is located at N-1 of $\beta$-lactam and replaces the usual 3,4,5-trimethoxyaryl ring A. Compound $14 \mathbf{b}$ with the para OEt substituent in Ring B produces a remarkably better antiproliferative effect $\left(\mathrm{IC}_{50}=0.045 \mu \mathrm{M}\right)$ than the para OMe for both 3-chloro and 3,3-dichloro compounds. 14b was identified as of particular interest and only slightly less potent than the corresponding 3,4,5-trimethoxy analogue $10 \mathbf{e}\left(\mathrm{IC}_{50}=0.034 \mu \mathrm{M}\right)$. The 3,4,5-trimethoxy substituted A Ring of CA-4 plays an important role in inhibiting tubulin polymerisation, confirmed by the crystal structure of CA-4 in tubulin [19]. It is interesting to see that the removal of the 4-methoxy group results in the retention of activity in the 3,5-dimethoxyaryl ring A compound 14b. The introduction of the 3-bromo substituent to replace the chloro at C-3 of the $\beta$-lactam resulted in a significant reduction in the antiproliferative effect of the compounds in the series, e.g., comparing compound $16 \mathrm{a}\left(\mathrm{IC}_{50}=0.579 \mu \mathrm{M}\right)$ with the corresponding 3-chloro compound $10 \mathrm{e}\left(\mathrm{IC}_{50}=0.034 \mu \mathrm{M}\right)$ resulted in a 17-fold decrease in activity.

The physicochemical properties and metabolic stability of the panel of compounds synthesised were evaluated to probe into the drug-relevant properties (see Supplementary Information Tables S1 and S2 for Tier 1 profiling screen). The physicochemical properties of the compounds complied with the Lipinski's rule of five, thus ensuring a good lipophilic-hydrophilic balance and adequate membrane permeability. Most of the compounds followed Lipinski and Veber rules, i.e., molecular weight ranges from 347 to 457, hydrogen bond acceptor range between four and nine, hydrogen bond donor range between zero and two, lipophilicity (AlogP) appeared in the range 2.67-4.76 (apart from the 4-naphthyl compound 11k, AlogP 5.84) and the number of rotatable bonds in the range 5-8. The calculated TPSA was between 48 and $130 \AA^{2}$, which suggested good intestinal absorption. The pharmacokinetics results indicate that these compounds satisfy the criteria for good drug likeness parameters and good bioavailability. The compounds were free from alerts for Pan Assay Interfering substances (PAINS) [76] and are predicted to have excellent drug-like properties (e.g., metabolic stability, permeability, blood-brain barrier partition, plasma protein binding and human intestinal absorption properties), which encouraged us to perform further in vitro studies. 
2.2.2. Antiproliferative Activity of Selected $\beta$-Lactam Compounds in the MDA-MB-231, Hs578T and Hs578Ts(i)8 Triple Negative Breast Cancer Cell Lines

Selected $\beta$-lactam compounds were next evaluated in the triple negative cell line MDA-MB-231 (Table 4). A total of $10-15 \%$ of breast cancers are classified as triple-negative breast cancers (TNBC) and include any breast cancer that does not express the genes for oestrogen and progesterone receptors (ER/PR) and HER2. In addition, MDA-MB-231 cells possess mutant p53. These cancers are difficult to treat since they are generally not responsive to hormone therapies such as the selective oestrogen receptor modulator (SERM) tamoxifen, or aromatase inhibitors such as anastrozole, or to the monoclonal antibody Herceptin, which targets the HER2 receptor. There are fewer treatment options available for TNBC compared with ER+, PR+ and HER2+ breast cancers and the prognosis is poorer [77,78]. The 3,3-dichloro- $\beta$-lactam 11n (with 3-hydroxy-4-methoxyphenyl Ring B substitution) was identified as the most potent with $\mathrm{IC}_{50}=0.0316 \mu \mathrm{M}$, similar to the $\mathrm{IC}_{50}$ value of $0.031 \mu \mathrm{M}$ obtained for $11 \mathrm{n}$ in the MCF-7 cell line. This result compares very favourably with the result obtained for CA-4 in the MDA-MB-231 cell line $\left(\mathrm{IC}_{50}=0.043 \mu \mathrm{M}\right)$, and is in good agreement with the reported values for CA-4 in this line [79]. The 3-chloro- $\beta$-lactam 10e (with 4-methoxphenyl Ring B) was found to have slightly less activity in the MDA-MB-231 cells $\left(\mathrm{IC}_{50}=0.0686 \mu \mathrm{M}\right)$ but retain a comparable potency in the MCF-7 cell line $\left(\mathrm{IC}_{50}=0.034 \mu \mathrm{M}\right)$. The 4-ethoxyphenyl compound 10f was also impressive in MDA-MB-231 cells with $\mathrm{IC}_{50}=0.078 \mu \mathrm{M}$, while compounds 10k, 11e and 11f were less active than in the MCF-7 cell lines with $\mathrm{IC}_{50}$ values of $0.205,0.297$ and $0.389 \mu \mathrm{M}$, respectively.

Table 4. Antiproliferative Effects of Selected $\beta$-Lactam Compounds in MDA-MB-231 Human Breast Cancer Cells.

\begin{tabular}{|c|c|}
\hline Compound Number & $\begin{array}{l}\text { Antiproliferative Activity }{ }^{a, b} \\
\text { IC }_{50}(\mu \mathrm{M}) \\
\text { MDA-MB-231, } 72 \mathrm{~h}\end{array}$ \\
\hline $10 \mathrm{e}$ & 0.0686 \\
\hline $10 f$ & $0.078 \pm 0.008$ \\
\hline $10 k$ & $0.205 \pm 0.034$ \\
\hline 11e & $0.297 \pm 0.04$ \\
\hline $11 f$ & $0.389 \pm 0.05$ \\
\hline $11 n$ & 0.0316 \\
\hline $\mathrm{CA}-4^{\mathrm{c}}$ & 0.043 \\
\hline
\end{tabular}

$\overline{{ }^{a}} \mathrm{IC}_{50}$ values are half maximal inhibitory concentrations required to block the growth stimulation of MDA-MB-231 cells. Values represent the mean (SEM) for three experiments performed in triplicate. ${ }^{b}$ The results for compounds $10 \mathrm{e}$ and $11 \mathrm{n}$ of antiproliferative activity against MDA-MB-231 were from NCI. ${ }^{c}$ The $\mathrm{IC}_{50}$ values obtained for CA-4 2a in this assay are $0.043 \mu \mathrm{M}$ for MDA-MB-231 and is in good agreement with the reported values for $2 \mathbf{a}$ using the MTT assay on MDA-MB-231 breast cancer cell lines (see Ref 79).

Compound 10e was further evaluated in the triple-negative Hs578T breast cancer cell line together with its isogenic subclone Hs578Ts(i) 8 cells. Hs578Ts(i) 8 cells are three-fold more invasive than the parental cell line (Hs578T) and 2.5-fold more migratory. Hs578Ts(i) 8 cells display enhanced invasive properties with 30\% more CD44+/CD24-/low cells. They show an increased capacity to proliferate, migrate, invade through the extracellular matrix and produce tumours in nude mice [80]. Compound 10e demonstrated significant antiproliferative activity at nanomolar concentrations in Hs578T cells ( $\left.\mathrm{IC}_{50} 124 \mathrm{nM}\right)$ with increased potency in the invasive Hs578Ts(i) 8 cells $\left(\mathrm{IC}_{50}=61 \mathrm{nM}\right)$. These results compared favourably with CA-4 ( $\mathrm{IC}_{50}=8 \mathrm{nM}$ in Hs578T and $20 \mathrm{nM}$ in Hs578Ts(i) 8 cells) and indicated the potential ability of the compound to inhibit tumour invasion and angiogenesis, which are characteristic features of tumour growth and metastasis in aggressive breast cancers. 
2.2.3. Antiproliferative Activity of Selected $\beta$-Lactam Compounds in Multiple Myeloma (U266), Acute Myeloid Leukaemia (HL60) and Colon Cancer (HT-29 and SW480) Cell Lines

Compounds 10n and 10e were next evaluated for antiproliferation in multiple myeloma (U266) cells. Multiple myeloma, also known as plasma cell myeloma, is a malignant haematological disease characterised by the proliferation of clonal plasma cells predominantly in the bone marrow. U266 cells are considered to be the least sensitive multiple myeloma cells to nucleoside drug cladribine compared to RPMI8226 and MM1.S cells [81]. Compounds 10n and 10e as well as CA-4, demonstrated potent antiproliferative activity in the nanomolar range, with an $\mathrm{IC}_{50}$ value of $77 \mathrm{nM}$ for the 3-chloro compound 10e (with 4-methoxyphenyl Ring B substitution) and a more potent result for the 3-chloro analogue (with 3-hydroxy-4-methoxyphenyl Ring B substitution) 10n, with $\mathrm{IC}_{50}=31 \mathrm{nM}$, which compares favourably with CA-4 $\left(\mathrm{IC}_{50}=35 \mathrm{nM}\right)$ in this cell line, Table 5. These results demonstrated the sensitivity of U266 cells toward CA-4 and its 3-chloroazetidinone analogues 10e and 10n.

Table 5. Antiproliferative effects of selected $\beta$-lactam compounds 10e, 10n and 11n in MCF-7 human breast, HL-60 leukaemia, U266 multiple myeloma, SW480 and HT-29 colon cancer cell lines.

\begin{tabular}{|c|c|c|c|c|c|}
\hline Compound & $\begin{array}{c}\text { MCF-7 } \\
\mathrm{IC}_{50}(\mu \mathrm{M})^{a}\end{array}$ & $\begin{array}{c}\text { HL-60 } \\
\text { IC }_{50}(\mu \mathrm{M})^{a}\end{array}$ & $\begin{array}{c}\mathrm{U} 266 \\
\mathrm{IC}_{50}(\mu \mathrm{M})^{\mathrm{a}}\end{array}$ & $\begin{array}{c}\text { SW480 } \\
\mathrm{IC}_{50}(\mu \mathrm{M})^{\mathrm{a}}\end{array}$ & $\begin{array}{c}\text { HT-29 } \\
\text { IC }_{50}(\mu \mathrm{M})^{a}\end{array}$ \\
\hline $10 \mathrm{e}$ & $0.056 \pm 0.007$ & $0.161 \pm 0.020$ & $0.077 \pm 0.02$ & $0.055 \pm 0.004$ & $0.135 \pm 0.060$ \\
\hline $10 n$ & $0.017 \pm 0.009$ & $0.010 \pm 0.008$ & $0.031 \pm 0.01$ & $0.037 \pm 0.005$ & $0.631 \pm 0.030$ \\
\hline $11 n$ & $0.031 \pm 0.004$ & $0.016 \pm 0.005$ & $\mathrm{nd}^{\mathrm{c}}$ & $0.044 \pm 0.008$ & $0.941 \pm 0.060$ \\
\hline CA-4 & $0.0039 \pm 0.00032^{b}$ & $0.0019 \pm 0.0005$ & $0.035 \pm 0.01$ & $0.003 \pm 0.0008$ & $4.165 \pm 0.1$ \\
\hline
\end{tabular}

${ }^{\mathrm{a}} \mathrm{IC}_{50}$ values are half maximal inhibitory concentrations required to block the growth stimulation of MCF-7 HL-60, U266, SW480 and HT-29 cells. Values represent the mean (SEM error values $10^{-6}$ ) for three experiments performed in triplicate at $72 \mathrm{~h} .{ }^{\mathrm{b}}$ The $\mathrm{IC}_{50}$ value obtained for CA-4 in this assay is in good agreement with the reported value (see refs $75,82,83){ }^{c}$ nd: not determined.

The 3-chloro $\beta$-lactam 10n was next evaluated in the HL-60 cell line (acute myeloid leukaemia), the colon adenocarcinoma cell line SW480 and also in the HT-29 human colorectal adenocarcinoma cell line. 10n demonstrated a potent effect with $\mathrm{IC}_{50}$ values of 10,37 and $631 \mathrm{nM}$, respectively, that compared favourably with the $\mathrm{IC}_{50}$ values for CA-4 we obtained in these cell lines of $2 \mathrm{nM}$ (HL-60), $3 \mathrm{nM}$ (SW480) and $4.165 \mathrm{mM}$ (HT-29), respectively (Table 5) and are in agreement with the reported values for CA-4 in MCF-7 and human breast cancer and leukaemia cell lines [74,82,83]. The corresponding values for 10e in these cell lines were $161 \mathrm{nM}$ (HL-60), $55 \mathrm{nM}$ (SW480) and $135 \mathrm{nM}$ (HT-29). The 3,3-dichloro $\beta$-lactam 11n was slightly less potent than 10n in these cell lines with $\mathrm{IC}_{50}$ values of $16 \mathrm{nM}$ (HL-60), $44 \mathrm{nM}$ (SW480) and $941 \mathrm{nM}$ (HT-29), respectively. These results are interesting as the control drug CA-4 $\left(\mathrm{IC}_{50}\right.$ value of $\left.4.165 \mu \mathrm{M}\right)$ is much less active than compounds 10n and 11n in the chemoresistant HT-29 cell line. This effect may be due to the inactivation of CA-4 by glucuronidation in HT-29 cells, as previously reported [74]. SW480 colon cells expressed low levels of the UDP-glucuronosyltransferase (UGT) protein compared to expression levels in HT-29 cells. The 3-bromoazetidinones $\mathbf{1 6 a - h}$ and $\mathbf{1 6 \mathbf { j }}$ demonstrated significantly less potent activity in the SW480 colon cancer cells, with 16a, $\mathbf{1 6 b}$ and 16j being the most effective with a 52,50 and 48\% inhibition of cell viability when evaluated at a $10 \mu \mathrm{M}$ concentration, Table 3 . The antiproliferative results for the most potent compound 10n in cell lines MCF-7, HL-60, SW480, HT-29, HL-60 and U266 are summarised in Table 5, together with the lead compound 10e and CA-4. 


\subsubsection{NCI Cell Line Screening for $\beta$-Lactam Compounds 10e, 11n and 16d}

The novel 3-haloazetidinone compounds $10 \mathrm{e}, \mathbf{1 1} \mathrm{n}$ and $\mathbf{1 6 \mathrm { d }}$ were selected by NCI for further biological evaluation in the NCI 60 cell line screen following an initial Tier 1 profiling screen [84]. The results obtained for the 3-haloazetidinone compounds 10e, 11n and $16 \mathrm{~d}$ in the NCI 60 cancer cell line screening $\left(\mathrm{GI}_{50}\right.$ values, five doses) are shown in Table 6. $\left(\mathrm{GI}_{50}\right.$ is the concentration of the compound required to produce $50 \%$ of the maximal inhibition of cell proliferation.) The compounds showed broad-spectrum antiproliferative activity against leukaemia, non-small cell lung, colon, CNS, melanoma, ovarian, renal, breast and prostate cancer cell lines and confirmed the results obtained with compounds 10e, 11n and 16d in MCF-7 cells in our laboratory with $\mathrm{GI}_{50}$ values of 34,31 and $44 \mathrm{nM}$, respectively. The mean $\mathrm{GI}_{50}$ values over the full 60 cell line panel for compounds 10e and 11n of 74.13 and $53.70 \mathrm{nM}$, respectively, compare very favourably with CA-4 (GI 50 value $99 \mathrm{nM})$, while the mean $\mathrm{GI}_{50}$ value for the 3-bromo $16 \mathrm{~d}$ is $407 \mathrm{nM}$. The 3,3-dichloroazetidinone CA-4 analogue 11n displayed potent activity in the NCI screen, with a mean $\mathrm{GI}_{50}$ value of $53.7 \mathrm{nM}$ for all the NCI cell lines tested; these values were in the sub-micromolar range for all the cell lines tested except for the breast cancer cell line T-47D, where the progesterone receptors are not regulated by estradiol [85]. For compound $11 n$, the $\mathrm{GI}_{50}$ values obtained were below $100 \mathrm{nM}$ for 43 of the cell lines investigated. Compound 11n was particularly effective against the non-small cell lung ( $\mathrm{GI}_{50}$ value $\left.16.4-46.4 \mathrm{nM}\right)$, CNS (GI 50 value 19.9-51.4 nM), prostate ( $\mathrm{GI}_{50}$ value $35.3-35.9 \mathrm{nM}$ ) cancer cell lines and also in the breast cancer cell lines tested (22.6-42.8 nM) apart from T-47D. The mean $\mathrm{LC}_{50}$ values (concentration required to kill $50 \%$ of the cells) over 60 cell lines for the potent compounds 10e and 11n were 91.20 and $83.18 \mu \mathrm{M}$, respectively (Table 7), and were greater than $100 \mu \mathrm{M}$ in all but one cell line for 10e and greater than $100 \mu \mathrm{M}$ in all but four cell lines examined for compound 11n, indicating low toxicity and suggesting that these compounds may be suitable for therapeutic development.

From the results obtained above, it is apparent that the inclusion of the chloro substituent on the $\beta$-lactam scaffold (as in compound 10n) results in greater antiproliferative effects in the MCF-7 cell line ( $\left.\mathrm{IC}_{50}=0.0175 \mu \mathrm{M}\right)$ than the corresponding 3,3-dichloro compound $(11 n)\left(\mathrm{IC}_{50}=0.031 \mu \mathrm{M}\right)$. By comparison, the introduction of a 3-bromo substituent on the $\beta$-lactam scaffold resulted in decreased antiproliferative activity, e.g., compound 16a $\left(\mathrm{IC}_{50}=0.579 \mu \mathrm{M}\right)$ compared with the corresponding 3-chloro compound 10e $\left(\mathrm{IC}_{50}=0.034 \mu \mathrm{M}\right)$. The antiproliferative activity of the most potent $\beta$-lactam compounds 10e, 10n and 11n may be correlated to the $\log \mathrm{P}$ values for some compounds (see Table 3 and Supplementary Information, Tables S1 and S2). The most potent 3-chloro compound $10 \mathrm{n}\left(\mathrm{IC}_{50}=0.0175 \mu \mathrm{M}\right)$ has a lower $\log \mathrm{P}(2.666)$ when compared to the 3,3-dichloro compound $11 \mathrm{n}\left(\mathrm{IC}_{50}=0.031 \mu \mathrm{M}\right)(\log \mathrm{P} 3.85)$; and the 3-bromo compound $16 \mathrm{a}\left(\mathrm{IC}_{50}=0.579 \mu \mathrm{M}\right)$ $(\log \mathrm{P} 3.543)$ has a higher $\log \mathrm{P}$ value when compared with the corresponding 3-chloro compound 10e $\left(\mathrm{IC}_{50}=0.034 \mu \mathrm{M}\right) \log \mathrm{P}=3.40$, suggesting that compounds with higher $\log \mathrm{P}$ values displayed poorer activity. However, 3-chloro-4-(2-naphthyl) compound 10k $\left(\mathrm{IC}_{50}=0.20 \mu \mathrm{M}\right)$ and 3,3-dichloro-4-(2-naphthyl) compound 11k $\left(\mathrm{IC}_{50}=0.322 \mu \mathrm{M}\right)$ retained potency, although with higher $\log \mathrm{P}$ values (4.66 and 5.84, respectively). Interestingly, the 2-naphthyl 10k was much more potent $\left(\mathrm{IC}_{50}=0.20 \mu \mathrm{M}\right)$ than the 1-naphthyl compound $10 \mathrm{j}\left(\mathrm{IC}_{50}=14.66 \mu \mathrm{M}\right)$, both with the same $\log \mathrm{P}$ value (4.66); a similar trend was observed in 3,3-dichloro-1-naphthyl compounds $11 \mathrm{j}\left(\mathrm{IC}_{50}=7.990 \mu \mathrm{M}\right)$ and 2-naphthyl compound $11 \mathrm{k}\left(\mathrm{IC}_{50}=0.322 \mu \mathrm{M}\right)$, which is possibly related to the steric difficulty in accommodating the 1-naphthyl ring at the colchicine binding site, whereas the 2-naphthyl ring is a better substitute for the 3,4,5-trimethoxyaryl ring $\mathrm{A}$. This effect is also reported for the 1- and 2-naphthyl analogues of CA-4 [86]. 
Table 6. Antitumour Evaluation of compounds 10e, 11n and 16d in NCI-60 cell line screen a

\begin{tabular}{|c|c|c|c|c|}
\hline \multirow[t]{2}{*}{ Cell Line } & & \multirow{2}{*}{$\begin{array}{c}\text { Compound 10e } \\
\mathrm{GI}_{50}(\mu \mathrm{M})^{\mathrm{b}, \mathrm{c}}\end{array}$} & \multirow{2}{*}{$\begin{array}{l}\text { Compound 11n } \\
\text { GI }_{50}(\mu \mathrm{M})^{\mathrm{b}, \mathrm{d}}\end{array}$} & \multirow{2}{*}{$\begin{array}{r}\text { Compound 16c } \\
\mathrm{GI}_{50}(\mu \mathrm{M})^{\mathrm{b}, \mathrm{e}, \mathrm{j}} \\
\end{array}$} \\
\hline & & & & \\
\hline \multirow[t]{9}{*}{ NSC Lung Cancer } & A549/ATCC & 0.0785 & 0.0382 & 0.598 \\
\hline & EKVX & 0.0694 & 0.0464 & 0.639 \\
\hline & HOP-62 & 0.0538 & 0.0350 & 0.336 \\
\hline & HOP-92 & $\mathrm{Nd}^{\mathrm{f}}$ & $\mathrm{Nd}^{\mathrm{f}}$ & 0.443 \\
\hline & NCI-H226 & 0.0557 & 0.0368 & 3.11 \\
\hline & NCI-H23 & 0.0312 & 0.0242 & 0.478 \\
\hline & NCI-H332M & 0.962 & $\mathrm{Nd}^{\mathrm{f}}$ & 7.37 \\
\hline & NCI-H460 & 0.306 & 0.0354 & 0.539 \\
\hline & NCI-H552 & 0.0207 & 0.0164 & 0.158 \\
\hline \multirow[t]{7}{*}{ Colon Cancer } & COLO205 & 0.0492 & 2.91 & 0.230 \\
\hline & НСТ-2998 & 0.0804 & 0.0534 & 0.673 \\
\hline & HCT-116 & 0.0397 & 0.0328 & 0.222 \\
\hline & HCT-15 & 0.0504 & 0.0383 & 0.210 \\
\hline & HT29 & 0.0292 & 2.78 & 0.351 \\
\hline & KM12 & 0.0393 & 0.0318 & 0.202 \\
\hline & SW-620 & 0.0432 & 0.0376 & 0.236 \\
\hline \multirow{6}{*}{ CNS Cancer } & SF-268 & 0.158 & 0.0514 & 1.18 \\
\hline & SF295 & 0.0254 & 0.0387 & 0.0870 \\
\hline & SF539 & $\mathrm{Nd}^{\mathrm{f}}$ & $\mathrm{Nd}^{\mathrm{f}}$ & 0.161 \\
\hline & SNB-19 & 0.0746 & 0.0457 & 0.440 \\
\hline & SNB-75 & 0.0382 & 0.0199 & 0.509 \\
\hline & U251 & 0.0370 & 0.0325 & 0.345 \\
\hline \multirow[t]{2}{*}{ Prostate cancer } & PC-3 & 0.0441 & 0.0353 & 0.297 \\
\hline & DU-145 & 0.0446 & 0.0359 & 0.349 \\
\hline \multirow[t]{9}{*}{ Melanoma } & LOX IMV1 & 0.0676 & 0.0415 & 0.834 \\
\hline & MALME-3M & 0.0884 & 0.0685 & 11.3 \\
\hline & M14 & 0.0396 & 0.0313 & 0.128 \\
\hline & MDA-MB-435 & 0.0226 & 0.0202 & 0.0377 \\
\hline & SK-MEL-2 & 0.0450 & 0.0316 & 0.484 \\
\hline & SK-MEL-28 & 0.0696 & 0.0629 & 1.94 \\
\hline & SK-MEL-5 & 0.0312 & 0.0225 & 0.0861 \\
\hline & UACC-257 & 23.3 & 0.158 & 14.3 \\
\hline & UACC-62 & 0.0518 & 0.0422 & 0.0972 \\
\hline \multirow{7}{*}{ Ovarian Cancer } & IGROV1 & 0.0580 & 0.0445 & 0.0630 \\
\hline & OVCAR-3 & 0.0241 & 0.0244 & 0.109 \\
\hline & OVCAR-4 & 0.106 & 0.0741 & 1.43 \\
\hline & OVCAR-5 & 0.0806 & 0.312 & 0.431 \\
\hline & OVCAR-8 & $\mathrm{Nd}^{\mathrm{f}}$ & $\mathrm{Nd}^{\mathrm{f}}$ & 0.403 \\
\hline & NCI/ADR-RES & 0.0353 & 0.0265 & 0.125 \\
\hline & SK-OV-3 & 0.182 & 0.0254 & 0.392 \\
\hline \multirow{8}{*}{ Renal Cancer } & $786-0$ & 0.0694 & 0.0412 & 0.340 \\
\hline & A498 & 0.0271 & 0.0226 & 0.103 \\
\hline & $\mathrm{ACHN}$ & 0.0971 & 0.0511 & $\mathrm{Nd}^{\mathrm{f}}$ \\
\hline & CAKI-1 & 0.122 & 0.126 & $\mathrm{Nd}^{\mathrm{f}}$ \\
\hline & RXF 393 & 0.0271 & 0.0300 & 0.170 \\
\hline & SN12C & 0.0837 & 0.0446 & 0.925 \\
\hline & TK-10 & 0.0922 & 0.126 & 14.3 \\
\hline & UO-31 & 0.0644 & 0.0821 & 0.342 \\
\hline
\end{tabular}


Table 6. Cont.

\begin{tabular}{|c|c|c|c|c|}
\hline \multirow{9}{*}{ Breast Cancer } & MCF-7 & 0.0343 & 0.0310 & 0.0447 \\
\hline & $\begin{array}{l}\text { MDA-MB- } \\
231 / \text { ATCC }\end{array}$ & 0.0686 & 0.0316 & 0.488 \\
\hline & HS 578T & 0.0553 & 0.0428 & 0.229 \\
\hline & BT-549 & 0.174 & 0.0397 & 0.525 \\
\hline & $\mathrm{T}-47 \mathrm{D}$ & 15.8 & 11.6 & 16.9 \\
\hline & MDA-MB-468 & 0.0508 & 0.0226 & 0.154 \\
\hline & $\mathrm{MID} \mathrm{GI}_{50} \mathrm{~g}$ & 0.0741 & 0.0537 & 0.407 \\
\hline & MID TGI ${ }^{h}$ & 23.4 & 10.7 & 10.0 \\
\hline & $\operatorname{MID~LC}{ }_{50}{ }^{\mathrm{i}}$ & 81.3 & 91.2 & 83.2 \\
\hline
\end{tabular}

a Data obtained from NCI in vitro human tumour cell screen 5 dose assay. ${ }^{\mathrm{b}}$ GI50 is the molar concentration of the compound causing a 50\% inhibition of growth of the tumour cells; ${ }^{\mathrm{c}}$ NSC 762040; ${ }^{\mathrm{d}}$ NSC 762041; ${ }^{\mathrm{e}}$ NSC 792961; ${ }^{\mathrm{f}} \mathrm{Nd}$ : Not determined; ${ }^{\mathrm{g}}$ MID GI50: MG-MID Full panel mean-graph mid-point; ${ }^{\mathrm{h}}$ TGI (total growth inhibition) TGI is the mean concentration required to completely inhibit the growth of all cells over the total NCI 60 cell line panel; ${ }^{i}$ LC50 is the mean concentrations required to kill $50 \%$ of the cells over the total NCI 60 cell line panel in the assay. ${ }^{j}$ GI50 values determined in leukaemia cell lines for compound 16d are CCRF-CEM (0.278), HL-60(TB) (0.214), K-562 (0.0545), MOLT-4 (0.347), RPMI-8226 (0.361) and SR (0.0765) $\mu \mathrm{M}$.

Table 7. Summary of NCI 60 cell line screening results for selected compounds.

Compound NCI Ref. No

${ }^{\mathrm{a}} \mathrm{GI}_{50}$ and $\mathrm{LC}_{50}$ are the concentrations required to inhibit the growth and kill $50 \%$ of the cells in the assay, respectively. ${ }^{\mathrm{b}}$ TGI is the concentration required to completely inhibit the growth of all cells.

The $\mathrm{GI}_{50}$, TGI and $\mathrm{LC}_{50}$ results of $\beta$-lactams $10 \mathrm{e}, 11 \mathrm{n}$ and $16 \mathrm{~d}$ are summarised in Table 7. The COMPARE algorithm was used to compare the $\mathrm{GI}_{50}$ and TGI results for compounds 10e, 11n and 16d with compounds of a known mechanism of action in the NCI Standard Agents Database (Table S3, Supplementary information) and allows correlations in drug sensitivities and molecular targets for biologically active compounds. The highest correlations for potent compounds $10 \mathrm{e}$ and $\mathbf{1 1 n}$ were obtained for tubulin-targeting agents, including the clinically used vinca alkaloids vincristine sulfate and vinblastine sulfate, together with maytansine. ADC T-DM1 contains an analogue mertansine conjugated with trastuzumab and is used in the treatment of metastatic HER-2 positive breast cancer [3]. 
2.2.5. Antiproliferative Activity of $\beta$-Lactam Compound 10n in Non-Carcinogenic Human Cells

The toxicity and selectivity of 10n towards normal cells was investigated in the non-tumourigenic cell line HEK-293T (normal human epithelial embryonic kidney cells). The cell viability of HEK-293T cells was significantly higher than MCF-7 cells following treatment with concentrations of $10 \mathrm{n}$ of 10,1 and $0.5 \mu \mathrm{M}$ for $72 \mathrm{~h}$ (Figure 4 ). The $\mathrm{IC}_{50}$ value of 10n in HEK-293 cells $(5.5 \mu \mathrm{M})$ compared favourably with that observed against the MCF-7 cell line $\left(\mathrm{IC}_{50}=17.5 \mathrm{nM}\right)$, demonstrating that $\beta$-lactam $10 \mathrm{n}$ was less toxic to human normal cells than cancer cells. These data suggested the compound 10n could be developed as a broad-spectrum anti-cancer agent with lower cytotoxicity to normal cells compared with MCF-7 cancer cells. The cytotoxic effect of selected 3-chloro- $\beta$-lactams 10e, 10f, 10i, 10n and 3,3-dichloro- $\beta$-lactams 11e and 11n in MCF-7 cells was initially determined using the lactate dehydrogenase ( $\mathrm{LDH}$ ) assay [87]. The 3 -chloro- $\beta$-lactams produced low cytotoxicity (at $10 \mu \mathrm{M}$ ) over $24 \mathrm{~h}$ with 5,4 and $3 \%$ cell death, for compounds 10e, 10f and 10i, respectively, while the 3,3-dichloro compound 11e demonstrated increased cytotoxicity $(10 \%)$. Compound 10n (3-hydroxy-4-methoxyphenyl Ring B), which was the most potent compound in the cell proliferation assays, resulted in increased cytotoxicity (17\% cell death), while the similarly substituted 3,3-dichloro compound 11n displayed lower cytotoxicity of an $8 \%$ cell death in this assay. CA-4 (positive control) resulted in a $12 \%$ cell death at $10 \mu \mathrm{M}$.

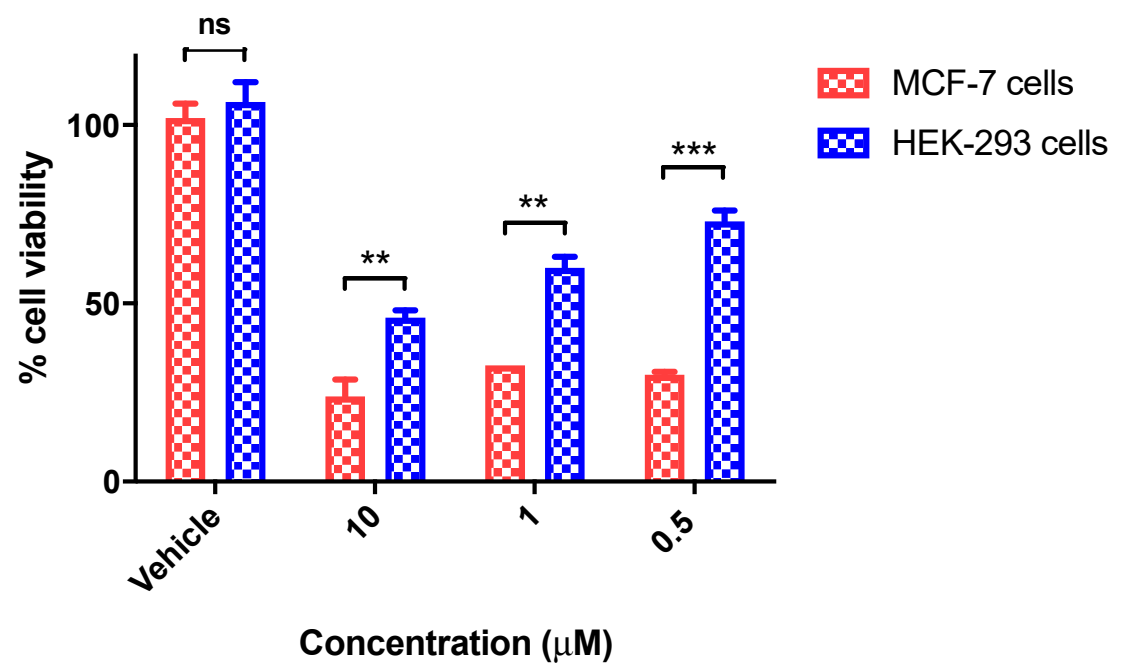

Figure 4. Effect of compound 10n on the viability of MCF-7 cells and non-tumorigenic HEK-293T cells. Cells were grown in 96-well plates and treated with compound 10n at $0.5,1$ and $10 \mu \mathrm{M}$ for $72 \mathrm{~h}$. Cell viability was expressed as a percentage of vehicle control (ethanol 1\% $(v / v)$ ) treated cells and was measured using an AlamarBlue assay (average of three independent experiments). Two-Way ANOVA (Bonferroni post-test) was used to test for statistical significance $\left({ }^{* *}, p<0.05,{ }^{* *}, p<0.001\right)$.

2.2.6. $\beta$-Lactam Compound 10n Induces Cell Cycle Arrest and Apoptosis in MCF-7 Cells

To further investigate the mechanism of action of the novel $\beta$-lactam compounds synthesised, the effect of $\beta$-lactam compound 10n was investigated on the cell cycle profile of MCF-7 cells. Flow cytometry and propidium iodide (PI) staining facilitate the quantification of the percentage of cells in each phase of the cell cycle (Figure 5). The values obtained for the percentage of cells in $\mathrm{G}_{0} / \mathrm{G}_{1}$, sub- $\mathrm{G}_{1}$ (indicative of apoptosis) and the $\mathrm{G}_{2} / \mathrm{M}$ phases of the cell cycle were quantified (at 50 and $500 \mathrm{nM}$ concentrations) and at three time points $(24,48$ and $72 \mathrm{~h}$ ), as shown in Figure 5. The percentage of cells in the $\mathrm{G}_{2} / \mathrm{M}$ phase $(81.3 \%(24 \mathrm{~h}), 77.5(48 \mathrm{~h})$ and $63.4 \%(72 \mathrm{~h}))$ following treatment with sample $10 \mathrm{n}(500 \mathrm{nM})$ was substantially greater than for the control sample treated with the vehicle (21-27\%). The observed induction of $\mathrm{G}_{2} / \mathrm{M}$ cell cycle arrest suggests that compound 10 n is an inhibitor of tubulin polymerisation. The percentage of cells undergoing apoptosis (sub- $\mathrm{G}_{1}$ ) increases at all three time points to $25 \%$ at $72 \mathrm{~h}(500 \mathrm{nM})$ compared to the basal 
apoptosis level of $7 \%$ observed with the vehicle ethanol at $72 \mathrm{~h}$. The percentage of cells in the $\mathrm{G}_{0} \mathrm{G}_{1}$ phase was observed at $8.5 \%(500 \mathrm{nM})$, while the untreated cells were $50.7 \%$ at $72 \mathrm{~h}$, indicating that the cells are coming out of the $\mathrm{G}_{0} \mathrm{G}_{1}$ phase and are undergoing $\mathrm{G}_{2} / \mathrm{M}$ followed by apoptosis. Similar effects on the cell cycle of MCF-7 cells were observed for the control drug CA-4 with a significant increase in the percentage of cells in $\mathrm{G}_{2} \mathrm{M}$ arrest $(52 \%, 100 \mathrm{nM})$ with an increase in apoptosis (sub- $\left.\mathrm{G}_{1}\right)(9.4 \%)$ [88]. In summary, compound 10n was found to induce $\mathrm{G}_{2} / \mathrm{M}$ arrest in MCF-7 cells in a time dependent manner, followed by apoptosis.

To further investigate the effects of compound 10 $\mathrm{n}$ on the induction of cellular apoptosis, MCF-7 cells were treated with compound 10n for $48 \mathrm{~h}$ and then stained with Annexin Vfluorescein isothiocyanate (FITC)/propidium iodide (PI). Following analysis using flow cytometry, differentiation between live cells (annexin- $\mathrm{V}^{-} / \mathrm{PI}^{-}$), early apoptotic cells (annexin$\mathrm{V}^{+} / \mathrm{PI}^{-}$), late apoptotic cells (annexin- $\mathrm{V}^{+} / \mathrm{PI}^{+}$) and necrotic cells (annexin- $\mathrm{V}^{-} / \mathrm{PI}^{+}$) is possible with dual staining with Annexin-V and PI, see Figure 6. Compound 10n induced both early and late apoptosis in MCF-7 cells in a concentration-dependent manner when compared to the untreated control cells (Figure 6). When MCF-7 cells were treated with 10n, the total apoptotic cells (Annexin V-stained positive cells) increased in a dose-dependent manner from $29.8 \%$ at $50 \mathrm{nM}$ to $37 \%$ at $500 \mathrm{nM}$. In contrast, only $5.0 \%$ of the total apoptotic cells were detected in the control cells $(0.1 \%$ ethanol $(v / v)$ treated sample). In comparison, the Annexin V-stained positive cells (total apoptotic) cells for CA-4 were determined as $34.6 \%$ in MCF-7 cells at $50 \mathrm{nM}$, as shown in Figure 6. These results demonstrated that compound 10n induced cell apoptosis in MCF-7 breast cancer cells.

\subsubsection{Effects of Compound 10n on Tubulin Polymerisation in MCF-7 Cells}

The tubulin binding activities of potent compounds 10e and 11n evaluated in MCF7 cells were carried out using a tubulin polymerisation assay kit from Cytoskeleton (BK006P) [89]. In this assay, light is scattered by microtubules to an extent that is proportional to the concentration of the microtubule polymer. The compounds were tested at $10 \mu \mathrm{M}$ concentration with purified and unpolymerised tubulin. The results for the selected $\beta$-lactam compounds are shown in Table 8 . The initial assay performed established the effects of compounds 10e and 11n on tubulin polymerisation for $30 \mathrm{~min}$ (Figure 7, Table 8). Ethanol and CA-4 (2a) were used as a vehicle and a positive control, respectively. CA-4 is one of the most effective anti-tubulin natural products. Both compounds 10e and 11n showed moderate tubulin polymerisation inhibition effects, although they were less effective than CA-4. When evaluated at a $10 \mu \mathrm{M}$ concentration, the 3-chloro and 3,3-dichloro compounds reduced the $\mathrm{V}_{\max }$ value for the rate of tubulin polymerisation 1.7-fold for compound 11n and 1.8-fold for compound 10e, whereas CA-4 induced a 6.3-fold reduction (Figure 7, Table 8 and Supplementary Information Figure S1). In general, the tubulin polymerisation inhibition activities of selected compounds depend on the substitutions at the C-3 and C-4 position of $\beta$-lactam core. The compounds with chloro and dichloro substituents at the C-3 position, such as 10e and 11n, exhibited moderate tubulin polymerisation inhibition and demonstrated some correlation with the antiproliferative effects of these compounds. 


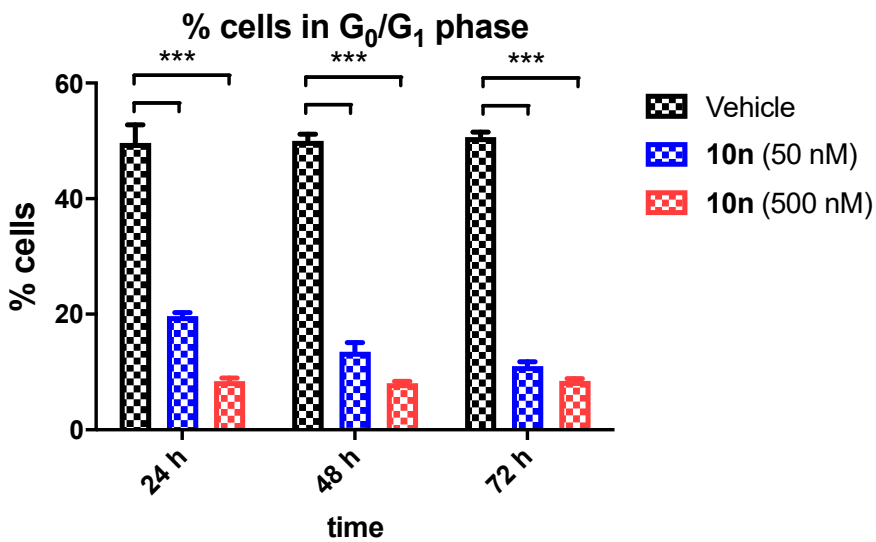

(A)

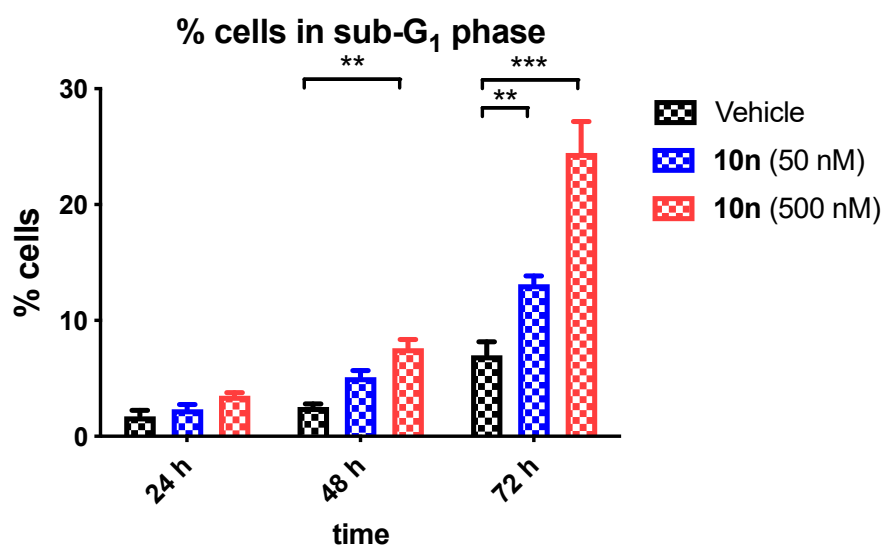

(B)

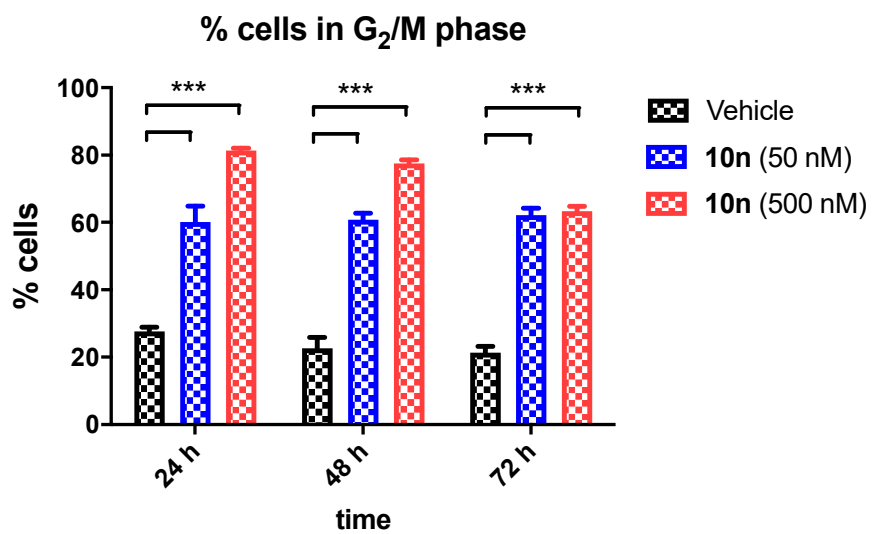

(C)

Figure 5. Compound 10n cells induced $\mathrm{G}_{2} / \mathrm{M}$ arrest followed by apoptosis in a time dependent manner in MCF-7 cells. (A) \% of cells in $\mathrm{G}_{0} / \mathrm{G}_{1}$ phase, (B) \% of cells in sub- $\mathrm{G}_{1}$ phase and (C) $\%$ of cells in $\mathrm{G}_{2} / \mathrm{M}$ phase. Cells were treated with either vehicle control $(\mathrm{v})(0.1 \%$ ethanol $(v / v))$ or compound 10n (50 and $500 \mathrm{nM}$ ) for 24, 48 or $72 \mathrm{~h}$. Cells were then fixed, stained with PI and analysed using flow cytometry. Cell cycle analysis was performed on histograms of gated counts per DNA area (FL2-A). The number of cells with $<2 \mathrm{~N}$ (sub- $\left.\mathrm{G}_{1}\right), 2 \mathrm{~N}\left(\mathrm{G}_{0} / \mathrm{G}_{1}\right)$ and $4 \mathrm{~N}\left(\mathrm{G}_{2} / \mathrm{M}\right)$ DNA content was determined with CellQuest software. Values represent the mean \pm SEM for three separate experiments. Two-Way ANOVA (Bonferroni post-test) was used to test for statistical significance $\left(^{* *}, p<0.05 ;{ }^{* * *}, p<0.001\right)$. 

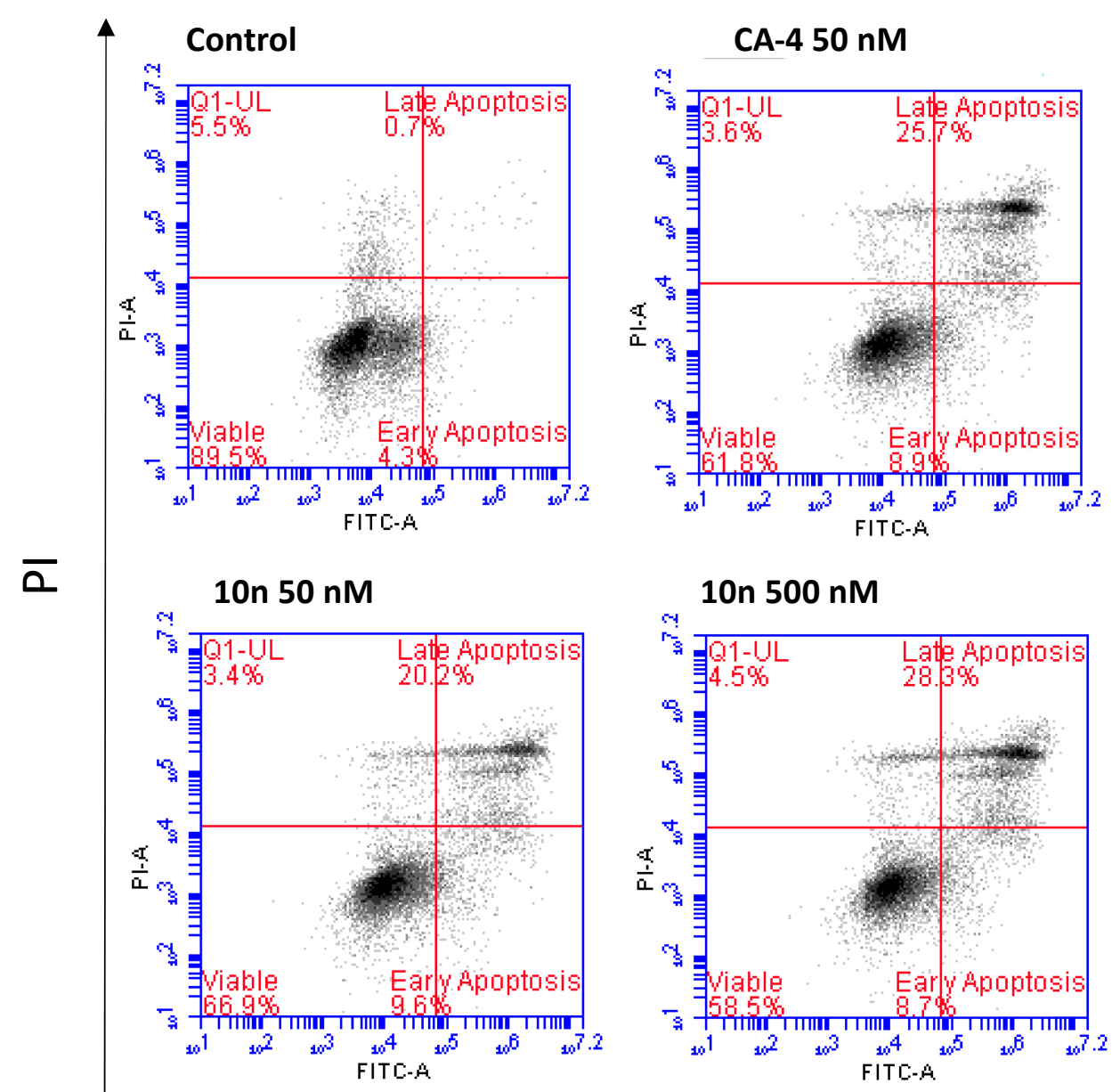

\section{Annexin $\mathrm{V}$}

Figure 6. Compound 10n induced apoptosis in MCF-7 breast cancer cells at $48 \mathrm{~h}$. MCF-7 breast cancer cells were treated with $10 \mathrm{n}(50$ and $500 \mathrm{nM})$ or CA-4 $(50 \mathrm{nM})$ or control vehicle $(0.1 \%$ ethanol $(v / v))$. The percentage of apoptotic cells was determined by staining with Annexin V-FITC and propidium iodide (PI). In each panel, the upper left quadrant shows only PI cells that are necrotic, while the lower left quadrant shows cells that are negative for both PI and Annexin V-FITC. The upper right quadrant shows both Annexin/PI positive, which are in late apoptosis/necrosis, while the lower right quadrant shows Annexin positive cells that are in the early apoptotic stage. Cells treated with CA-4 (50 nM) and 10n (50 and $500 \mathrm{nM}$ ) and control cells at $48 \mathrm{~h}$ are shown, respectively. Values represent the mean of three independent experiments.

Table 8. Inhibition of tubulin polymerisation for compounds $10 \mathrm{e}, \mathbf{1 1 n}$ and CA-4 and their corresponding $\mathrm{IC}_{50}$ values in MCF-7 and MDA-MB-231 breast cancer cells.

\begin{tabular}{ccccc}
\hline $\begin{array}{c}\text { Compound } \\
\text { Number }\end{array}$ & $\begin{array}{c}\text { MCF-7 } \\
\mathbf{I C}_{\mathbf{5 0}}(\boldsymbol{\mu M})^{\mathbf{a}}\end{array}$ & $\begin{array}{c}\text { MDA-MB-231 } \\
\mathbf{I C}_{\mathbf{5 0}}(\boldsymbol{\mu M})^{\mathbf{a}}\end{array}$ & $\begin{array}{c}\mathbf{V}_{\text {max }} \text { at } \mathbf{1 0} \boldsymbol{\mu M} \\
(\mathbf{m O D} / \mathbf{m i n})\end{array}$ & Fold-Reduction $^{\mathbf{b}}$ \\
\hline $\mathbf{1 0 e}$ & $0.034 \pm 0.004$ & 0.0686 & 0.0039 & 1.8 \\
$\mathbf{1 1 n}$ & $0.031 \pm 0.005$ & 0.0316 & 0.0041 & 1.7 \\
CA-4 & $0.0039 \pm 0.00032$ & 0.043 & 0.0022 & 6.3 \\
\hline
\end{tabular}

${ }^{\mathrm{a}} \mathrm{IC}_{50}$ values are the compound concentration required to inhibit cell proliferation by $50 \%$. Data are expressed as the mean \pm S.E.M. from the dose-response curves of at least three independent experiments performed in triplicate. ${ }^{\mathrm{b}}$ The $\mathrm{V}_{\max }$ values at $10 \mu \mathrm{M}(\mathrm{mOD} / \mathrm{min})$ for the vehicle ethanol is $0.0069 .{ }^{\mathrm{c}}$ Fold inhibition of tubulin polymerisation was calculated using $\mathrm{V}_{\max }$ value for each reaction. 


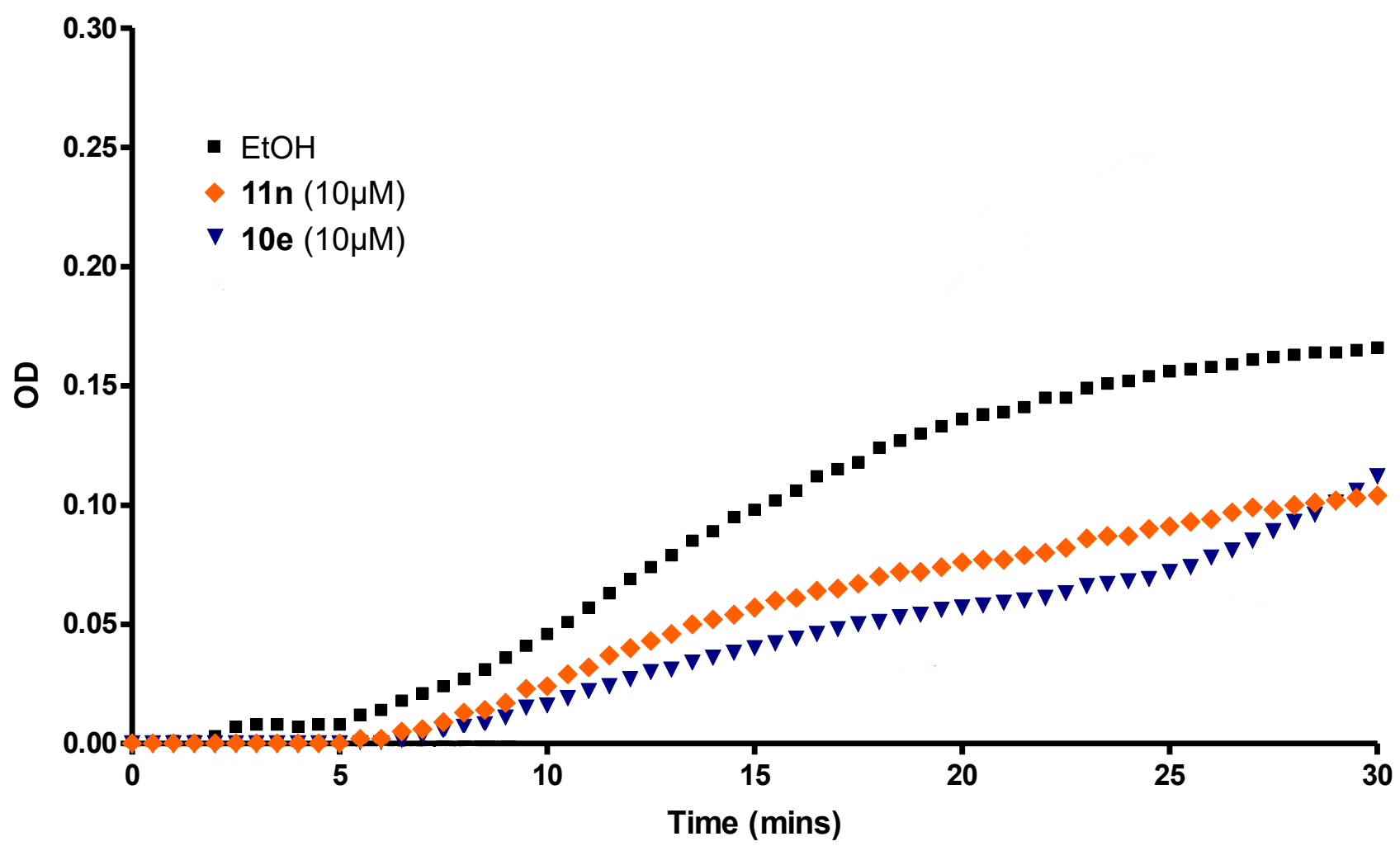

Figure 7. Tubulin polymerisation assay for compounds 10e and 11n. Compounds 10e and 11n induce depolymerisation of tubulin in vitro. Effect of compounds 10e and 11n on in vitro tubulin polymerisation: compounds $10 \mathrm{e}$ and $11 \mathrm{n}(10 \mu \mathrm{M}$ concentration) were first mixed with purified bovine tubulin in a 96-well plate on ice. Purified bovine tubulin and GTP were mixed in a 96 -well plate at $37^{\circ} \mathrm{C}$. Ethanol $(1 \% v / v)$ was used as a vehicle control. The final concentration of bovine tubulin was $3 \mathrm{mg} / \mathrm{mL}$ and glycerol was $10 \%$. After placing the plate into a $37^{\circ} \mathrm{C}$ incubator, the effect on tubulin assembly (OD_optical density) was monitored in a Spectramax $340 \mathrm{PC}$ spectrophotometer for $30 \mathrm{~min}$ at $37^{\circ} \mathrm{C}$ and $340 \mathrm{~nm}$ in $30 \mathrm{~s}$ intervals. Percentage inhibition of polymerisation was recorded for each reaction. The results represent the mean for three separate experiments performed in duplicate.

Subsequently, the effect of the representative compound 10n on the organisation of microtubule cytoskeleton of MCF-7 cells was also determined by confocal microscopy using an anti-tubulin antibody (Figure 8). As expected, the MCF-7 cells exhibited a wellorganised microtubular network (stained green) when treated with the vehicle control ( $0.1 \%$ ethanol). The MCF-7 cell nuclei (stained blue) were also clearly observed (Figure $8 \mathrm{~A})$. In contrast, the fibrous microtubule structures were disorganised, and their densities were also significantly reduced by treating the MCF-7 cells with compound 10n. The paclitaxeltreated sample (Figure 8C) showed the hyper-polymerisation of tubulin, while the extensive depolymerisation of tubulin was demonstrated in the CA-4-treated sample Figure 8B. Cells treated with the $\beta$-lactam compound 10n $(0.05,0.1$ and $0.5 \mu \mathrm{M})$ displayed a disorganised microtubule network with similar effects to CA-4, together with multinucleation (Figure 8D-F). The treatment of MCF-7 breast cancer cells with CA-4 tubulin-targeting agents has been reported to result in the formation of multiple micronuclei and mitotic catastrophes [90-92]. These immunofluorescence studies for the visualisation of the microtubule network in MCF-7 cells confirmed that compound 10n could directly inhibit the tubulin polymerisation.

A colchicine-site binding assay was performed to evaluate the interaction of compound 10n at the colchicine binding site of tubulin using $N, N$-ethylenebis(iodoacetamide) (EBI) $[93,94]$. EBI crosslinks the Cys-239 and Cys-354 residues of the colchicine binding site of $\beta$-tubulin, alkylating the sulfhydryl group of cysteine. This covalent EBI adduct occupies the colchicine binding site of $\beta$-tubulin and can be detected using Western blotting as it appears at a lower position than tubulin, indicating that Cys239 and Cys354 amino acids 
of $\beta$-tubulin are crosslinked with EBI. Microtubule targeting compounds binding at the colchicine site, e.g., colchicine and CA-4, prevent the formation of the $\beta$-tubulin-EBI adduct. MCF-7 cells were treated with 10n $(10 \mu \mathrm{M})$ or CA-4 $(10 \mu \mathrm{M})$, followed by EBI $(100 \mu \mathrm{M})$. Control samples (ethanol $0.1 \%(v / v)$ ) indicated the formation of the $\beta$-tubulin-EBI adduct at a slightly lower position (Figure 9). Tubulin EBI adduct formation was inhibited in the MCF-7 cells treated with CA-4 and 10n, indicating that both CA-4 and 10n bind to the colchicine binding site of tubulin. These tubulin polymerisation inhibitors act on the colchicine site of tubulin and compete with EBI to bind the colchicine binding site and hinder the cross-linking of EBI with $\beta$-tubulin.

\section{(A) Control}

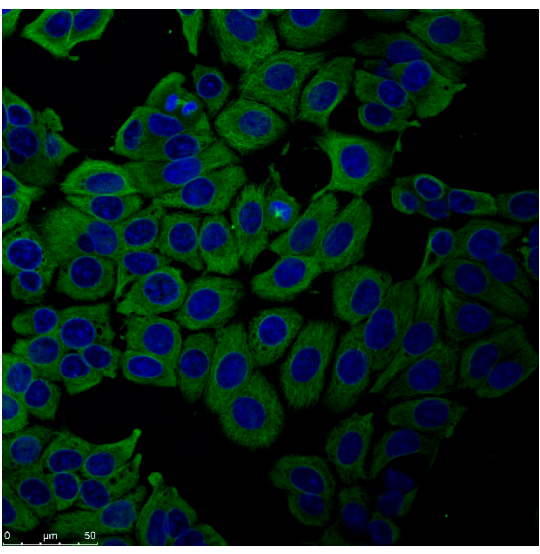

(D) $10 \mathrm{n}(50 \mathrm{nM})$

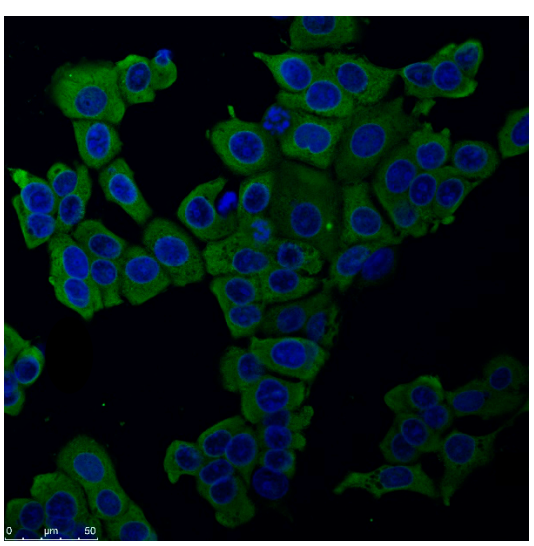

(B) $\quad \mathrm{CA}-4(50 \mathrm{nM})$

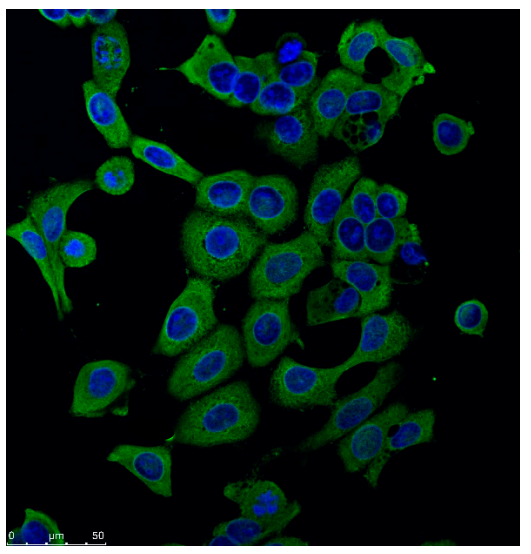

(E) $10 \mathrm{n}(100 \mathrm{nM})$

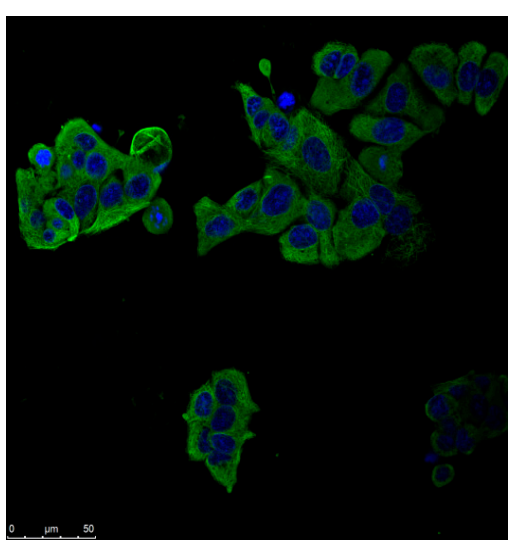

(C) Paclitaxel $(1 \propto \mathrm{M})$

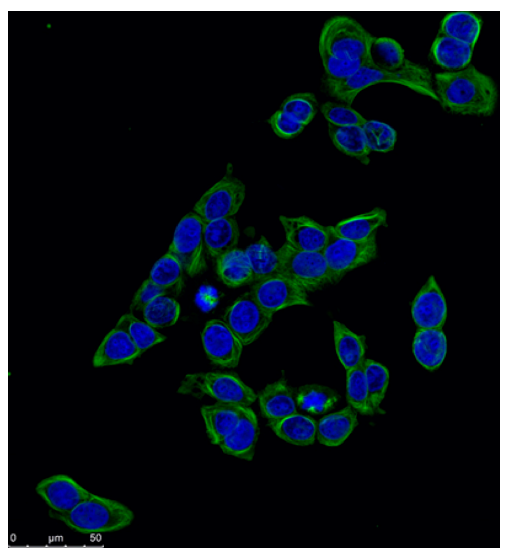

(F) $\quad 10 \mathrm{n}(500 \mathrm{nM})$

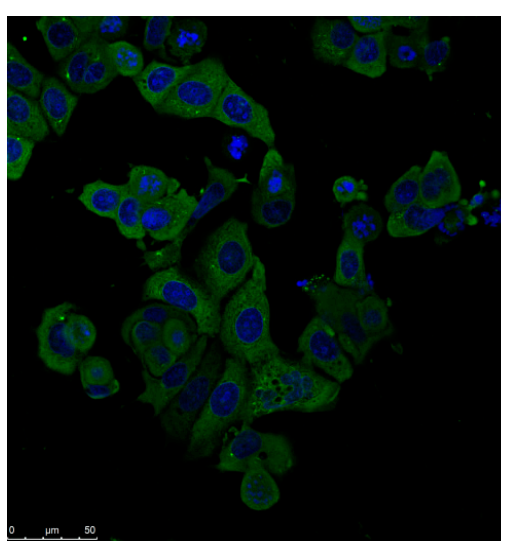

Figure 8. Compound 10n depolymerises the microtubule network of MCF-7 breast cancer cells. Cells were treated with (A) vehicle control $(0.1 \%$ ethanol $(v / v))$, (B) CA-4 $(50 \mathrm{nM}),($ C) paclitaxel $(1 \mu \mathrm{M})$ and compound 10n, (D) $(0.05 \mu \mathrm{M})$, (E) $(0.1 \mu \mathrm{M})$ and $(\mathrm{F})(0.5 \mu \mathrm{M})$ for $16 \mathrm{~h}$. Cells were fixed in ice-cold methanol and stained with mouse monoclonal anti- $\alpha$ tubulin-FITC antibody (clone DM1A) (green), Alexa Fluor 488 dye and counterstained with DAPI (blue). Images were obtained with Leica SP8 confocal microscopy with Leica application suite X software. Representative confocal micrographs of three separate experiments are shown. Scale bar indicates $25 \mu \mathrm{m}$. 


\section{$\frac{\text { Vehicle }}{-++} \frac{\text { CA-4 }}{-++} \frac{10 \mathrm{n}}{-++}$ \\ EBI \\ $55 \mathrm{kDa}$

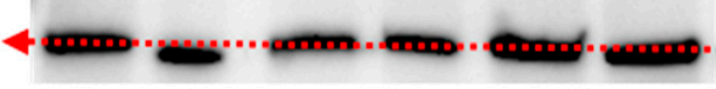 \\ MCF-7 cells}

\section{$38 \mathrm{kDa}$}
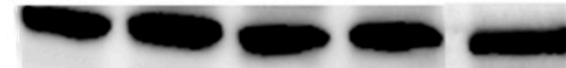

GAPDH

Figure 9. Effects of compound 10n on the inhibition of the bisthioalkylation of Cys239 and Cys354 of $\beta$-tubulin by $N, N^{\prime}$-ethylene-bis(iodoacetamide) (EBI) in MCF-7 cells. MCF-7 was treated with vehicle control (ethanol 0.1\% $(v / v)), \mathbf{C A}-4$ and 10n $(10 \mu \mathrm{M})$ for $2 \mathrm{~h}$; selected samples were then treated with EBI $(100 \mu \mathrm{M})$ for an additional $1.5 \mathrm{~h}$. Cells were harvested, lysed and analysed using sedimentation and Western blotting for $\beta$-tubulin and $\beta$-tubulin-EBI adducts. Results are indicative of two separate experiments, performed independently. To confirm equal protein loading, each membrane was stripped and re-probed with a GAPDH antibody.

2.2.8. Effects of Compound 10n on Expression Levels of Apoptosis-Associated Proteins Bax, Bcl-2 and Mcl-1 in MCF-7 Cells

The effects of compound 10n on the expression of the pro-apoptotic protein Bax and anti-apoptotic proteins Bcl-2 and Mcl-1 were next investigated using Western blot analysis. The Bcl-2 family of proteins controls and regulates the intrinsic or mitochondrial apoptotic pathway. Pro- and anti-apoptotic members of the Bcl-2 family can oligomerise at the mitochondrial outer membrane to regulate permeabilization, which is a central event in the intrinsic apoptotic pathway. The pro-apoptotic protein Bax, together with Bak, is a key member of the Bcl-2 family and is a core regulator of the intrinsic pathway of apoptosis [95]. Western blot analysis (Figure 10) demonstrated that the expression level of pro-apoptotic protein Bax was upregulated in a dose-dependent manner in MCF-7 cells after treatment with compound $10 \mathrm{n}(0.05,0.1$ and $0.5 \mu \mathrm{M})$ for 48 or $72 \mathrm{~h}$.

$48 \mathrm{~h}$

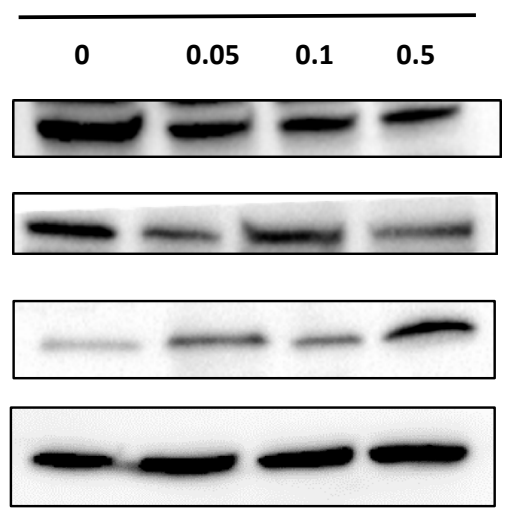

$72 \mathrm{~h}$

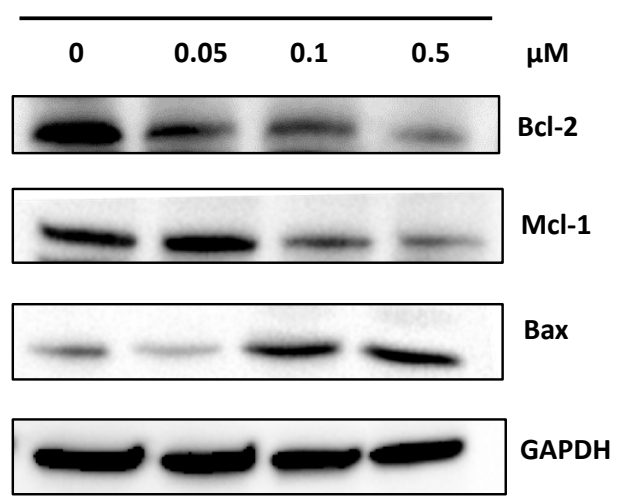

Figure 10. Effects of compound 10n on expression of pro-apoptotic protein Bax and anti-apoptotic proteins Bcl-2 and Mcl-1 in MCF-7 cells. MCF-7 cells were treated with either vehicle control (ethanol, $0.1 \% v / v$ ) or with compound 10n $(0.05,0.1$ and $0.51 \mu \mathrm{M})$ for 48 or $72 \mathrm{~h}$. After the required time, the cells were then harvested and separated using SDS PAGE to detect the level of the pro-apoptotic protein Bax and anti-apoptotic proteins Bcl-2 and Mcl-1. Results are representative of two separate experiments performed independently. To confirm equal protein loading, each membrane was stripped and re-probed with a GAPDH antibody. 
The apoptosis regulating proteins Bcl-2 and Mcl-1 were next investigated. The antiapoptotic or pro-survival Bcl-2 protein is also a member of the Bcl-2 family. It prevents the release of a pro-apoptotic AIF (apoptosis inducing factor) and cytochrome $\mathrm{c}$ from the mitochondria into the cytoplasm [96] and prevents apoptosis by sequestering caspases (apoptosis promoters). The level of the anti-apoptotic protein Bcl-2 was downregulated in a dosedependent manner after treating MCF-7 cells with compound 10n $(0.05,0.1$ and $0.5 \mu \mathrm{M})$ for 48 or $72 \mathrm{~h}$. (Figure 9). Mcl-1 protein (an induced myeloid leukaemia cell differentiation protein) is another key anti-apoptotic member of the Bcl-2 family and is localised in the mitochondrial outer membrane [97]. It binds and sequesters the pro-apoptotic Bax/Bak proteins and, thus, prevents the release of cytochrome c [98]. Overexpression of the anti-apoptotic factors Mcl-1, Bcl-2 and Bcl-xL in acute myeloid leukaemia [99] and acute lymphocytic leukaemia [100] may be associated dysregulation of apoptosis. The level of the anti-apoptotic protein Mcl-1 was downregulated in a dose-dependent manner after treating MCF-7 cells with compound 10n $(0.05,0.1$ and $0.5 \mu \mathrm{M})$ for 48 or $72 \mathrm{~h}$. (Figure 10). Apoptosis can be triggered by a reduction in the expression levels of Mcl-1 and Bcl-2 (e.g., by drug treatment). The increase in the percentage of cells observed in the sub- $\mathrm{G}_{1}$ peak, together with the flow cytometry analysis of Annexin V/PI-stained cells support the pro-apoptotic mechanism of action proposed for these compounds (Figures 5 and 6).

\subsection{Computational Modelling of $\beta$-Lactam Compounds 10n, $11 \mathrm{n}$ and $\mathbf{1 4 b}$}

Computational docking calculations using MOE 2019.01 [101] were undertaken on both enantiomers of the potent compounds trans-3-chloro-1-(3,4,5-trimethoxyphenyl)$\beta$-lactam 10n, 3,3-dichloro-1-(3,4,5-trimethoxyphenyl)- $\beta$-lactam 11n together with the 3 -chloro-1-(3,5-dimethoxyphenyl)- $\beta$-lactam $14 \mathbf{b}$, using the $X$-ray structure of bovine tubulin co-crystallised with N-deacetyl-N-(2-mercaptoacetyl)-colchicine (DAMA-colchicine) 1SA0 [6], Figure 11. ${ }^{1} \mathrm{H}$ NMR analysis determined that only the trans isomers of the compounds 10n and $14 \mathbf{b}$ were isolated; therefore, we modelled only the $3 S, 4 S$ and $3 R, 4 R$ enantiomeric pairs. In all cases, the $S, S$ enantiomers were more highly ranked than the corresponding $R, R$ enantiomeric pair; therefore, only they will be discussed. All trimethoxy compounds overlaid their B-rings on the C-ring of DAMA-colchicine (forming HBA interactions with Lys352), co-located the 3,4,5-trimethoxyphenyl substituted A-rings and were able to position the halogens in an open region of the tubulin binding site at the monomer interface. The predicted affinity ranking from best ranked to worst was 10n $S S, 14 \mathrm{~b} S S$, $11 \mathrm{n} S, 10 \mathrm{n} R R, 11 \mathrm{n} R$ and $14 \mathrm{~b} R R$. Generating conformers with OMEGA [1,2] and running docking with FRED [3] also gave the same preference for $S S$ over $R R$ enantiomers. Docking studies are not ideal for studying changes in cellular efficacy associated with different halogen substituents. While the SS enantiomer of the dimethoxy analogue $\mathbf{1 4 b}$ presented a comparable binding mode to other analogues in the tubulin site, it did not overlap fully with DAMA-colchicine (Figure 11, Panel C). The lack of a hydroxy group in Ring B of $\mathbf{1 4 b}$ to potentially hydrogen bond with Lys 352 and the added steric bulk, resulting from the substitution of 4-methoxy with 4-ethoxy on the B-ring, forced the molecule deeper into the binding site, resulting in the less favourable docking scores. The increase in lipophilicity could also decrease the cell permeability of $\mathbf{1 4 b}$, causing a slight loss in efficacy against MCF-7 cells. Figure 11 illustrates the best ranked binding pose of each compound, showing the shared binding mode across the analogues. 


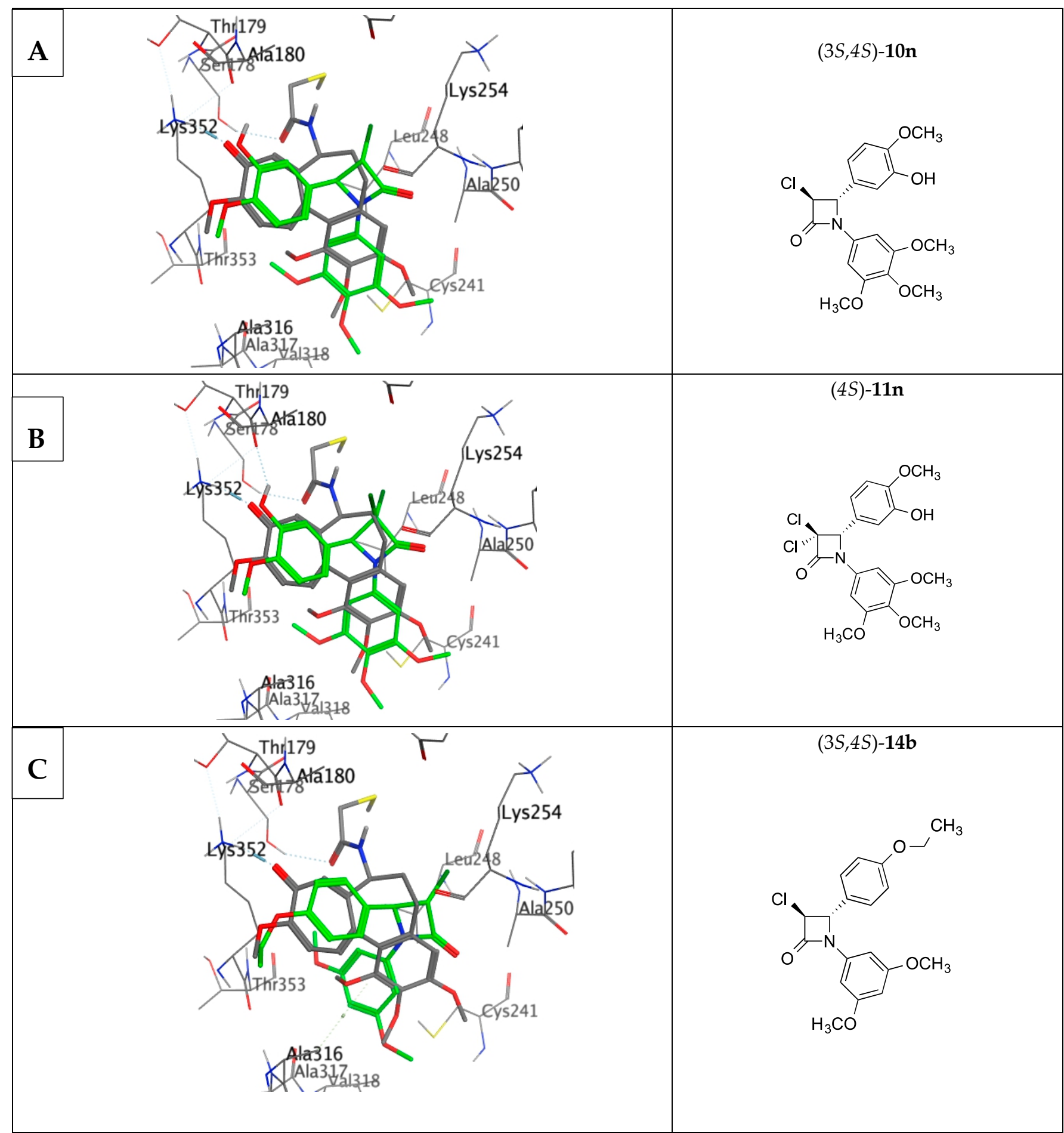

Figure 11. Overlay of the X-ray structure of tubulin co-crystallised with DAMA-colchicine (PDB entry 1SA0) on the best ranked docked poses of the $S$ enantiomers of the three studied beta-lactams: (A) 10n, (B) 11n and (C) 14b. Ligands are rendered as tube and amino acids as line. Tubulin amino acids and DAMA-colchicine are coloured by atom type: carbon = grey, hydrogen $=$ white, oxygen $=$ red, nitrogen $=$ blue, sulphur $=$ yellow, bromine $=$ dark red, chlorine $=$ dark green. The beta-lactams are depicted with a green backbone. The atoms are coloured by element type, Key amino acid residues are labelled, and multiple residues are hidden to enable a clearer view. 


\section{Materials and Methods}

3.1. Chemistry

All chemicals were commercially purchased and were used without further purification unless otherwise indicated. Solvents were either purchased dry or purified by distillation in accordance with literature methods. Dichloromethane was dried by distillation from calcium hydride prior to use. Tetrahydrofuran (THF) was distilled immediately prior to use from $\mathrm{Na}$ /Benzophenone under nitrogen. Toluene was dried by distillation from calcium hydride and stored on activated molecular sieves $(4 \AA)$. Melting points were determined on a Gallenkamp SMP 11 melting point apparatus and are uncorrected. Infra-red (IR) spectra were recorded as $\mathrm{KBr}$ discs, thin films on $\mathrm{NaCl}$ disk or ATR on a Perkin Elmer FT-IR Paragon 1000 spectrometer. ${ }^{1} \mathrm{H}$ and ${ }^{13} \mathrm{C}$ nuclear magnetic resonance (NMR) spectra were recorded at $20^{\circ} \mathrm{C}$ on a Bruker DPX 400 spectrometer $(400.13 \mathrm{MHz}$, ${ }^{1} \mathrm{H} ; 100.61 \mathrm{MHz},{ }^{13} \mathrm{C}$ ) in $\mathrm{CDCl}_{3}$, DMSO- $d_{6}$ or $\mathrm{CD}_{3} \mathrm{OD}$ by Dr. John $\mathrm{O}^{\prime}$ Brien and Dr. Manuel Ruether in the School of Chemistry, Trinity College Dublin, with internal standard TMS. The chemical shifts are given in ppm relative to $\mathrm{Me}_{4} \mathrm{Si}$ as an internal reference, $J$ values are given in Hz. High resolution mass spectrometry (HRMS) was obtained in the School of Chemistry by Dr Martin Feeney or the School of Pharmacy and Pharmaceutical Sciences by Mr Brian Talbot, Trinity College Dublin. HRMS was carried on in the positive ion mode on a liquid chromatography time-of flight mass spectrometer (Micromass LCT, Waters Ltd., Manchester, UK). The samples were introduced into the ion source by an LC system (Waters Alliance 2795, Waters Corporation, Milford, MA, USA) in acetonitrile:water $(60: 40 \% v / v)$ at $200 \mu \mathrm{L} / \mathrm{min}$. A lock (reference) mass $(m / z$ 556.2771) was used. High resolution mass spectrometry scans were also performed using Electrospray Ionisation operated in negative and positive ion modes on an LTQ/Orbitrap Discovery Mass Spectrometer, and samples were dissolved in $\mathrm{CH}_{3} \mathrm{OH}$, with a mass accuracy of $< \pm 5 \mathrm{ppm}$. Low resolution mass spectra (LRMS) were obtained on a Hewlett-Packard 5973 MSD GC-MS system in electron impact (EI) mode. Thin layer chromatography was performed with Merck silica gel 60 TLC aluminium sheets using a fluorescent indicator visualising at $254 \mathrm{~nm}$ in UV. Merck Kiesegel 60 (particle size $0.040-0.063 \mathrm{~mm}$ ) was used for flash column chromatography. Preparative chromatography was also carried out on a Biotage SP4 instrument. All products isolated were homogenous on TLC. Microwave experiments were performed with the Biotage Initiator and Discover CEM microwave synthesisers. Purity of the finial compounds was achieved using analytical high-performance liquid chromatography (HPLC) using a Waters 2487 Dual Wavelength Absorbance detector, Waters 1525 binary HPLC pump, Waters In-Line Degasser AF and Waters 717plus Autosampler, with a Varian Pursuit XRs C18 reverse phase $250 \times 4.6 \mathrm{~mm}$ column and detection at $254 \mathrm{~nm}$. Samples were analysed using acetonitrile $(60 \%)$ :water $(40 \%)$ with $0.1 \%(v / v)$ TFA over $10 \mathrm{~min}$ and a flow rate of $1 \mathrm{~mL} / \mathrm{min}$. Imines $\mathbf{9 a - 9 j}, \mathbf{9 m}-\mathbf{9 s}, \mathbf{1 1 f}, \mathbf{1 1} \mathbf{i}, \mathbf{1 2 e}, \mathbf{1 2} \mathbf{f}$ and $\mathbf{1 2} \mathbf{i}$ were prepared as previously reported $[34,35,74,102]$. The details for the preparation of 3-azetidinones 10f, 10i, 10o, 11e, 11f, 11i and 11o were as previously reported [34,74] are provided in the Supplementary Information.

\subsubsection{General Method 1A: PREPARATION of Imines with Ethanol as Solvent $(\mathbf{9 k}, \mathbf{9 1}, \mathbf{9 t - \mathbf { v }})$ :}

The appropriately substituted benzaldehyde $(10 \mathrm{mmol})$ and corresponding substituted aniline $(10 \mathrm{mmol})$ were heated at reflux in ethanol $(40 \mathrm{~mL})$ for $4 \mathrm{~h}$. The reaction solvent was then reduced to approximately $10 \mathrm{~mL}$ in vacuo and the reaction mixture was allowed to stand for $12 \mathrm{~h}$. The precipitated product was filtered and then recrystallised from ethanol.

2-Methoxy-5-[(3,4,5-trimethoxyphenylimino)methyl]phenol (9k)

Compound 9k was prepared using the general method IA above and was obtained from 3-hydroxy-4-methoxybenzaldehyde and 3,4,5-trimethoxyaniline as a pale-yellow solid; yield: $89 \%, 2.82 \mathrm{~g}$, Mp. $134{ }^{\circ} \mathrm{C}$ [33]. IR V $\max (\mathrm{KBr}) 1613(\mathrm{C}=\mathrm{N}), 3347(\mathrm{OH}) \mathrm{cm}^{-1}$. ${ }^{1} \mathrm{H} \mathrm{NMR}\left(400 \mathrm{MHz}, \mathrm{CDCl}_{3}\right): \delta 3.83\left(\mathrm{~s}, 3 \mathrm{H},-\mathrm{OCH}_{3}\right), 3.92\left(\mathrm{~s}, 6 \mathrm{H},-\mathrm{OCH}_{3}\right), 3.98\left(\mathrm{~s}, 3 \mathrm{H},-\mathrm{OCH}_{3}\right)$, $5.72(\mathrm{~s}, 1 \mathrm{H},-\mathrm{OH}), 6.49\left(\mathrm{~s}, 2 \mathrm{H}, \mathrm{H}_{2^{\prime}}, \mathrm{H}_{6^{\prime}}\right), 6.95\left(\mathrm{~d}, 1 \mathrm{H}, J=8.52 \mathrm{~Hz}, \mathrm{H}_{5^{\prime}}{ }^{\prime}\right), 7.39(\mathrm{dd}, J=1.48 \mathrm{~Hz}$, 
8.28, $\left.1 \mathrm{H}, \mathrm{H}_{6^{\prime}}{ }^{\prime}\right), 7.54\left(\mathrm{~d}, J=1.48 \mathrm{~Hz}, 1 \mathrm{H}, \mathrm{H}_{2^{\prime}}{ }^{\prime}\right), 8.38(\mathrm{~s}, 1 \mathrm{H}, \mathrm{CH}=\mathrm{N}) .{ }^{13} \mathrm{C} \mathrm{NMR}(100 \mathrm{MHz}$, $\left.\mathrm{CDCl}_{3}\right): \delta 55.61,55.67,60.58\left(-\mathrm{OCH}_{3}\right), 97.96\left(\mathrm{C}_{2}, \mathrm{C}_{6}\right), 109.87\left(\mathrm{C}_{5^{\prime}}{ }^{\prime}\right), 113.31\left(\mathrm{C}_{2^{\prime}}{ }^{\prime}\right), 121.85\left(\mathrm{C}_{6^{\prime}}{ }^{\prime}\right)$, $129.49\left(\mathrm{C}_{1^{\prime}}{ }^{\prime}\right), 136\left(\mathrm{C}_{4^{\prime}}\right), 145.51\left(\mathrm{C}_{3^{\prime}}{ }^{\prime}\right), 147.71\left(\mathrm{C}_{1^{\prime}}\right), 153.08\left(\mathrm{C}_{4^{\prime}}\right),\left(\mathrm{C}_{3^{\prime}}, \mathrm{C}_{5^{\prime}}\right), 158.72(\mathrm{CH}=\mathrm{N})$. HRMS: found $318.1353[\mathrm{M}+\mathrm{H}]^{+} ; \mathrm{C}_{17} \mathrm{H}_{20} \mathrm{NO}_{5}$ requires 318.1341.

[3-(Tert-butyldimethylsilanyloxy)-4-methoxybenzylidene](3,4,5-trimethoxyphenyl)amine (91)

To a solution of the imine $9 \mathrm{k}$ ( $5 \mathrm{mmol}$ ) and tert-butyldimethylsilyl chloride $(6 \mathrm{mmol})$ in anhydrous DCM $(40 \mathrm{~mL})$ under a nitrogen atmosphere, DBU $(8 \mathrm{mmol})$ was added dropwise via a syringe. Stirring under nitrogen was continued until starting material had disappeared as monitored by TLC over $2-4 \mathrm{~h}$ (eluent, $50: 50$ hexane/ethyl acetate). Upon completion, the reaction was diluted with dichloromethane $(50 \mathrm{~mL})$. The reaction mixture was washed with water $(2 \times 100 \mathrm{~mL}), 0.1 \mathrm{M} \mathrm{HCl}$ aq $(2 \times 50 \mathrm{~mL})$ and saturated $\mathrm{NaHCO}_{3}$ solution $(2 \times 50 \mathrm{~mL})$ and dried over $\mathrm{Na}_{2} \mathrm{SO}_{4}$. The solvent was removed under reduced pressure to yield the protected Schiff base, which was used for $\beta$-lactam synthesis without further purification; yield: $78 \%, 1.68 \mathrm{~g}$, amber oil [36]. IR $V_{\max }$ (film) $1585 \mathrm{~cm}^{-1}$ $(\mathrm{C}=\mathrm{N}) .{ }^{1} \mathrm{H}$ NMR $\left(400 \mathrm{MHz}, \mathrm{CDCl}_{3}\right): \delta 0.20(\mathrm{~s}, 6 \mathrm{H},-t \mathrm{BDMSi}), 1.03(\mathrm{~s}, 9 \mathrm{H},-t \mathrm{BDMSi})$, $3.77\left(\mathrm{~s}, 3 \mathrm{H},-\mathrm{OCH}_{3}\right), 3.81\left(\mathrm{~s}, 6 \mathrm{H},-\mathrm{OCH}_{3}\right), 3.89\left(\mathrm{~s}, 3 \mathrm{H},-\mathrm{OCH}_{3}\right), 5.94\left(\mathrm{~s}, 2 \mathrm{H}, \mathrm{H}_{2^{\prime}}, \mathrm{H}_{6^{\prime}}\right)$, $6.48\left(\mathrm{~s}, 1 \mathrm{H}, \mathrm{H}_{5^{\prime}}\right), 6.92\left(1 \mathrm{H}, \mathrm{d}, J=8.52 \mathrm{~Hz}, \mathrm{H}_{2^{\prime}}{ }^{\prime}\right), 7.46\left(1 \mathrm{H}, \mathrm{m}, \mathrm{H}_{6^{\prime}}{ }^{\prime}\right)$ and $8.35(1 \mathrm{H}, \mathrm{s}$, imine $)$. ${ }^{13} \mathrm{C}$ NMR $\left(100 \mathrm{MHz}, \mathrm{CDCl}_{3}\right)$ : $\delta$-5.67, 18.07, 25.26 (-tBDMSi), 54.99, 55.64, $60.62\left(-\mathrm{OCH}_{3}\right)$, $92.12\left(\mathrm{C}_{2^{\prime}}, \mathrm{C}_{6^{\prime}}\right), 110.96\left(\mathrm{C}_{5^{\prime}}{ }^{\prime}\right), 119.74\left(\mathrm{C}_{2^{\prime}}{ }^{\prime}\right), 123.42\left(\mathrm{C}_{6^{\prime}}{ }^{\prime}\right), 128.95\left(\mathrm{C}_{1^{\prime}}{ }^{\prime}\right), 144.50\left(\mathrm{C}_{4^{\prime}}\right), 144.87\left(\mathrm{C}_{3^{\prime}}{ }^{\prime}\right)$, $147.94\left(\mathrm{C}_{1^{\prime}}\right), 153.06\left(\mathrm{C}_{3^{\prime}}, \mathrm{C}_{5^{\prime}}\right), 153.40\left(\mathrm{C}_{4^{\prime}}{ }^{\prime}\right), 158.82(\mathrm{C}=\mathrm{N})$. HRMS: found $431.2127[\mathrm{M}]^{+}$; $\mathrm{C}_{23} \mathrm{H}_{33} \mathrm{NO}_{5} \mathrm{Si}$ requires 431.2128 .

\section{(E)-N-(4-Methoxyphenyl)-1-(3,4,5-trimethoxyphenyl)methanimine (9t)}

Compound $9 t$ was prepared using the general method IA above from 4-methoxyaniline and 3,4,5-trimethoxy benzaldehyde as pale-yellow crystals; yield: 70\%, Mp. $115^{\circ} \mathrm{C}$ [103] (HPLC: 95\%). IR V $\max (A T R): 1622.8(\mathrm{C}=\mathrm{N}) \mathrm{cm}^{-1} .{ }^{1} \mathrm{H}$ NMR $\left(400 \mathrm{MHz}, \mathrm{CDCl}_{3}\right): \delta 3.85\left(\mathrm{~s}, 6 \mathrm{H}, \mathrm{OCH}_{3}\right)$, $3.90\left(\mathrm{~s}, 6 \mathrm{H}, \mathrm{OCH}_{3}\right), 6.96(\mathrm{~d}, J=8.03 \mathrm{~Hz}, 2 \mathrm{H}, \mathrm{ArH}), 7.18(\mathrm{~s}, 2 \mathrm{H}, \mathrm{ArH}), 7.26(\mathrm{~d}, J=8.03 \mathrm{~Hz}, 2 \mathrm{H}$, $\mathrm{ArH}), 8.40(\mathrm{~s}, 1 \mathrm{H}, \mathrm{CH}=\mathrm{N}) .{ }^{13} \mathrm{C} \mathrm{NMR}\left(100 \mathrm{MHz}, \mathrm{CDCl}_{3}\right): \delta 55.0,55.8,60.6,105.1,106.2,113.9$, 116.2, 131.4, 140.3, 153.0, 157.6 (imine, $\mathrm{HC}=\mathrm{NC}$ ), 161.9. HRMS: found $324.1198\left[\mathrm{M}+\mathrm{Na}^{+}\right.$; $\mathrm{C}_{17} \mathrm{H}_{19} \mathrm{NNaO}_{4}$ requires 324.1212 .

\section{(E)-N-(4-Ethoxyphenyl)-1-(3,4,5-trimethoxyphenyl)methanimine (9u)}

Compound $9 \mathbf{u}$ was synthesised using the general method IA above and was obtained from 4-ethoxyaniline and 3,4,5-trimethoxybenzaldehyde as yellow crystals; yield: $82 \%$, Mp: $98{ }^{\circ} \mathrm{C}$ [103] (HPLC: 99\%). IR $\mathrm{V}_{\max }$ (ATR): $1636.4 \mathrm{~cm}^{-1}$ (C=N). ${ }^{1} \mathrm{H}$ NMR $(400 \mathrm{MHz}$, $\left.\mathrm{CDCl}_{3}\right): \delta 1.41\left(\mathrm{t}, J=7.02 \mathrm{~Hz}, 3 \mathrm{H}, \mathrm{OCH}_{2} \mathrm{CH}_{3}\right), 3.89\left(\mathrm{~s}, 3 \mathrm{H}, \mathrm{OCH}_{3}\right), 3.93\left(\mathrm{~s}, 6 \mathrm{H}, \mathrm{OCH}_{3}\right), 4.04$ $\left(\mathrm{q}, J=6.71 \mathrm{~Hz}, 2 \mathrm{H}, \mathrm{OCH}_{2} \mathrm{CH}_{3}\right), 6.86-6.94(\mathrm{~m}, 2 \mathrm{H}, \mathrm{ArH}), 7.12(\mathrm{~s}, 2 \mathrm{H}, \mathrm{ArH}), 7.16-7.22(\mathrm{~m}, 2 \mathrm{H}$, $\mathrm{ArH}), 8.35(\mathrm{~s}, 1 \mathrm{H}, \mathrm{CH}=\mathrm{N}) .{ }^{13} \mathrm{C}$ NMR $\left(100 \mathrm{MHz}, \mathrm{CDCl}_{3}\right): \delta 14.85,56.21,60.94,63.66,97.31$, 105.49, 114.93, 122.10, 132.00, 140.64, 153.47, 157.57 (imine, HC=NC), 157.79. HRMS: found $338.1364[\mathrm{M}+\mathrm{Na}]^{+} ; \mathrm{C}_{18} \mathrm{H}_{21} \mathrm{NNaO}_{4}$ requires 338.1368.

\section{(E)-N-(4-(Methylthio)phenyl)-1-(3,4,5-trimethoxyphenyl)methanimine (9v)}

Compound $9 \mathrm{v}$ was synthesised using the general method IA above and was obtained from 4-methylthioaniline and 3,4,5-trimethoxybenzaldehyde as yellow crystals; yield: $92 \%$, Mp. $112{ }^{\circ} \mathrm{C}$ [103]. IR V $\max$ (ATR): $1677.8 \mathrm{~cm}^{-1}(\mathrm{C}=\mathrm{N}) .{ }^{1} \mathrm{H}$ NMR $\left(400 \mathrm{MHz}, \mathrm{CDCl}_{3}\right)$ : $\delta 2.48\left(\mathrm{~s}, 3 \mathrm{H}, \mathrm{SCH}_{3}\right), 3.86\left(\mathrm{~s}, 3 \mathrm{H}, \mathrm{OCH}_{3}\right), 3.96\left(\mathrm{~s}, 6 \mathrm{H}, \mathrm{OCH}_{3}\right), 7.14(\mathrm{~d}, J=8.54 \mathrm{~Hz}, 2 \mathrm{H}, \mathrm{ArH})$, 7.23-7.28 (m, 2H, ArH), $7.12(\mathrm{~s}, 2 \mathrm{H}, \mathrm{ArH}), 8.33(\mathrm{~s}, 1 \mathrm{H}, \mathrm{CH}=\mathrm{N}) .{ }^{13} \mathrm{C} \mathrm{NMR}\left(100 \mathrm{MHz}, \mathrm{CDCl}_{3}\right)$ : $\delta$ 16.34, 56.23, 60.96, 105.71, 121.50, 127.66, 131.69, 135.80, 140.95, 149.17, 153.49, 159.18 (imine, $\mathrm{HC}=\mathrm{NC}$ ). HRMS: found $340.0994[\mathrm{M}+\mathrm{Na}]^{+} ; \mathrm{C}_{17} \mathrm{H}_{19} \mathrm{NNaO}_{3} \mathrm{~S}$ requires 340.0983.

\subsubsection{General Method IB: Schiff Base Preparation with Water as a Solvent (9w, 9x)}

The appropriately substituted benzaldehyde $(10 \mathrm{mmol})$ and corresponding substituted aniline $(10 \mathrm{mmol})$ were stirred in water $(7 \mathrm{~mL})$ for $30 \mathrm{~min}$. The organic compound was 
extracted with DCM and the reaction mixture was dried over anhydrous sodium sulfate before the solvent was removed under reduced pressure.

(E)-N-(3,5-Dimethoxyphenyl)-1-(4-methoxyphenyl)methanimine (9w)

Compound $9 \mathrm{w}$ was prepared using the general method IB above and was obtained from 4-methoxybenzaldehyde and 3,5-dimethoxyaniline as an oil [50]; yield: 97\%, IR $\mathrm{V}_{\max }(\mathrm{ATR}): 1592.2 \mathrm{~cm}^{-1}(\mathrm{C}=\mathrm{N}) .{ }^{1} \mathrm{H}$ NMR $\left(400 \mathrm{MHz}, \mathrm{CDCl}_{3}\right): \delta 3.79\left(\mathrm{~s}, 6 \mathrm{H}, \mathrm{OCH}_{3}\right)$, $3.84\left(\mathrm{~s}, 3 \mathrm{H}, \mathrm{OCH}_{3}\right), 6.30-6.36(\mathrm{~m}, 3 \mathrm{H}, \mathrm{ArH}), 6.95(\mathrm{~d}, J=7.93 \mathrm{~Hz}, 2 \mathrm{H}, \mathrm{ArH}), 7.81(\mathrm{~d}, J=7.93 \mathrm{~Hz}$, $2 \mathrm{H}, \mathrm{ArH}), 8.35(\mathrm{~s}, 1 \mathrm{H}, \mathrm{CH}=\mathrm{N}) .{ }^{13} \mathrm{C} \mathrm{NMR}\left(100 \mathrm{MHz}, \mathrm{CDCl}_{3}\right): \delta 55.37,55.52,97.92,98.97$, $114.15,114.26,129.00,130.54,131.92,154.52,159.83$ (HC=NC). HRMS: calculated for $\mathrm{C}_{16} \mathrm{H}_{18} \mathrm{NO}_{3}[\mathrm{M}+\mathrm{H}]^{+}$272.1287; found 272.1289.

(E)-N-(3,5-Dimethoxyphenyl)-1-(4-ethoxyphenyl)methanimine (9x)

Compound $9 \mathbf{w}$ was prepared using the general method IB above and was obtained from 4-ethoxybenzaldehyde and 3,5-dimethoxyaniline as an oil; yield: $85 \%$. IR $\mathrm{V}_{\max }$ (ATR): $1597.6 \mathrm{~cm}^{-1}(\mathrm{C}=\mathrm{N}) .{ }^{1} \mathrm{H}$ NMR $\left(400 \mathrm{MHz}, \mathrm{CDCl}_{3}\right): \delta 1.43\left(\mathrm{t}, J=7.02 \mathrm{~Hz}, 3 \mathrm{H}, \mathrm{OCH}_{2} \mathrm{CH}_{3}\right)$, $3.80\left(\mathrm{~s}, 6 \mathrm{H}, \mathrm{OCH}_{3}\right), 4.09\left(\mathrm{q}, J=7.12 \mathrm{~Hz}, 2 \mathrm{H}, \mathrm{OCH}_{2} \mathrm{CH}_{3}\right), 6.22-6.44(\mathrm{~m}, 3 \mathrm{H}, \mathrm{ArH}), 6.90-7.00$ $(\mathrm{m}, 2 \mathrm{H}, \mathrm{ArH}), 7.80(\mathrm{~m}, J=8.55 \mathrm{~Hz}, 2 \mathrm{H}, \mathrm{ArH}), 8.35(\mathrm{~s}, 1 \mathrm{H}, \mathrm{CH}=\mathrm{N}) .{ }^{13} \mathrm{C} \mathrm{NMR}(100 \mathrm{MHz}$, $\left.\mathrm{CDCl}_{3}\right): \delta 14.71,55.40,63.64,97.90,98.97,114.64,130.55,153.22,159.93$ (HC=NC). HRMS: calculated for $\mathrm{C}_{17} \mathrm{H}_{20} \mathrm{NO}_{3}[\mathrm{M}+\mathrm{H}]^{+} 286.1443$; found 286.1456 .

3.1.3. General Method II: Preparation of 3-Chloroazetidin-2-ones, 3,3-Dichloroazetidin2-ones, 3-Bromoazetidin-2-ones (10a-o, 11a-o, 12a-c, 13a-c, 14a, 14b, 15a, 15b, 16a-h)

To a stirring, refluxing solution of the imine $(5 \mathrm{mmol})$ and triethylamine $(6 \mathrm{mmol})$ in anhydrous dichloromethane $(40 \mathrm{~mL})$, a solution of chloro- or dichloroacetyl chloride (6 mmol) in anhydrous dichloromethane $(10 \mathrm{~mL})$ was injected dropwise through a rubber septum over $45 \mathrm{~min}$ under nitrogen. The reaction was refluxed for $5 \mathrm{~h}$, and at retained at $20^{\circ} \mathrm{C}$ overnight under nitrogen. The reaction mixture was washed with water $(2 \times 100 \mathrm{~mL})$; the organic layer was dried over anhydrous sodium sulfate and the solvent was then removed under reduced pressure. The crude product was purified using flash chromatography over silica gel (eluent 4:1 $n$-hexane: ethyl acetate).

3-Chloro-1-(3,4,5-trimethoxyphenyl)-4-phenylazetidin-2-one (10a)

Compound 10a was prepared as described in the general method II above from imine 9a and chloroacetyl chloride; yield: $8 \%, 135 \mathrm{mg}$, brown oil (HPLC: 100\%). IR ( $\mathrm{NaCl}$, film) $\mathrm{V}_{\text {max }}$ : 2983, 2684, 1764 (C=O, $\beta$-lactam), 1601, 1507, 1235, $1127 \mathrm{~cm}^{-1} .{ }^{1} \mathrm{H}$ NMR $(400 \mathrm{MHz}$, $\left.\mathrm{CDCl}_{3}\right): \delta 3.71\left(\mathrm{~s}, 6 \mathrm{H}, \mathrm{OCH}_{3}\right), 3.79\left(\mathrm{~s}, 3 \mathrm{H}, \mathrm{OCH}_{3}\right), 4.67\left(\mathrm{br} \mathrm{s}, 1 \mathrm{H}, \mathrm{H}_{4}\right), 4.99\left(\mathrm{br} \mathrm{s}, 1 \mathrm{H}, \mathrm{H}_{3}\right)$, $6.54\left(\mathrm{~s}, 2 \mathrm{H}, \mathrm{H}_{2^{\prime}} \mathrm{H}_{6^{\prime}}\right), 7.40-7.46\left(\mathrm{~m}, 5 \mathrm{H}, \mathrm{H}_{2^{\prime}}{ }^{\prime} \mathrm{H}_{3^{\prime}} \mathrm{H}_{4^{\prime}}{ }^{\prime} \mathrm{H}_{5^{\prime}}{ }^{\prime} \mathrm{H}_{6^{\prime}}{ }^{\prime}\right) .{ }^{13} \mathrm{C} \mathrm{NMR}\left(100 \mathrm{MHz}, \mathrm{CDCl}_{3}\right)$ : $\delta 55.58,60.52\left(\mathrm{OCH}_{3}\right), 62.63\left(\mathrm{C}_{3}\right), 65.97\left(\mathrm{C}_{4}\right), 94.74\left(\mathrm{C}_{2^{\prime}}, \mathrm{C}_{6^{\prime}}\right), 125.74\left(\mathrm{C}_{2^{\prime}}, \mathrm{C}_{6^{\prime}}{ }^{\prime}\right), 129.06\left(\mathrm{C}_{3^{\prime}}{ }^{\prime}\right.$, $\left.\mathrm{C}_{5^{\prime}}{ }^{\prime}\right), 129.19\left(\mathrm{C}_{4^{\prime}}{ }^{\prime}\right), 132.46\left(\mathrm{C}_{4^{\prime}}\right), 134.52\left(\mathrm{C}_{1^{\prime}}\right), 134.65\left(\mathrm{C}_{1^{\prime}}{ }^{\prime}\right), 153.10\left(\mathrm{C}_{3^{\prime}}, \mathrm{C}_{5^{\prime}}\right), 160.15\left(\mathrm{C}_{2}\right)$. HRMS: found $370.0822[\mathrm{M}+\mathrm{Na}]^{+} ; \mathrm{C}_{18} \mathrm{H}_{18}{ }^{35} \mathrm{ClNO}_{4} \mathrm{Na}$ requires 370.0822 .

3-Chloro-4-(4-chlorophenyl)-1-(3,4,5-trimethoxyphenyl)azetidin-2-one (10b)

Compound $10 \mathrm{~b}$ was prepared as described in the general method II above from imine 9b and chloroacetyl chloride; yield: 9\%, $169 \mathrm{mg}$, brown oil. IR (NaCl, film) $\mathrm{V}_{\max }: 2605,2498$, 1766 (C=O, $\beta$-lactam), 1595, 1506, 1235, $1127 \mathrm{~cm}^{-1} .{ }^{1} \mathrm{H}$ NMR $\left(400 \mathrm{MHz}, \mathrm{CDCl}_{3}\right): \delta 3.73$ $\left(\mathrm{s}, 6 \mathrm{H}, \mathrm{OCH}_{3}\right), 3.78\left(\mathrm{~s}, 3 \mathrm{H}, \mathrm{OCH}_{3}\right), 4.61\left(\mathrm{~d}, 1 \mathrm{H}, J=1.48 \mathrm{~Hz}, \mathrm{H}_{4}\right), 4.98(\mathrm{~d}, 1 \mathrm{H}, J=2.00 \mathrm{~Hz}$, $\left.\mathrm{H}_{3}\right), 6.51\left(\mathrm{~s}, 2 \mathrm{H}, \mathrm{H}_{2^{\prime}} \mathrm{H}_{6^{\prime}}\right), 7.35\left(\mathrm{~d}, J=8.52 \mathrm{~Hz}, 2 \mathrm{H}, \mathrm{H}_{3^{\prime}}{ }^{\prime} \mathrm{H}_{5^{\prime}}{ }^{\prime}\right), 7.43\left(\mathrm{~d}, J=8.56 \mathrm{~Hz}, 2 \mathrm{H}, \mathrm{H}_{2^{\prime}}{ }^{\prime}\right.$ $\left.\mathrm{H}_{6^{\prime}}{ }^{\prime}\right) .{ }^{13} \mathrm{C}$ NMR $\left(100 \mathrm{MHz}, \mathrm{CDCl}_{3}\right): \delta 55.64,60.51\left(\mathrm{OCH}_{3}\right), 62.56\left(\mathrm{C}_{3}\right), 65.16\left(\mathrm{C}_{4}\right), 94.72$ $\left(\mathrm{C}_{2^{\prime}}, \mathrm{C}_{6^{\prime}}\right), 127.03\left(\mathrm{C}_{2^{\prime}}, \mathrm{C}_{6^{\prime}}{ }^{\prime}\right), 129.32\left(\mathrm{C}_{3^{\prime}}{ }^{\prime}, \mathrm{C}_{5^{\prime}}{ }^{\prime}\right), 132.19\left(\mathrm{C}_{4^{\prime}}{ }^{\prime}\right), 133.05\left(\mathrm{C}_{4^{\prime}}\right), 134.84\left(\mathrm{C}_{1^{\prime}}\right), 135.12$ $\left(\mathrm{C}_{1^{\prime}}{ }^{\prime}\right), 153.19\left(\mathrm{C}_{3^{\prime}}, \mathrm{C}_{5^{\prime}}\right), 159.84\left(\mathrm{C}_{2}\right)$. HRMS: found $404.0449[\mathrm{M}+\mathrm{Na}]^{+} ; \mathrm{C}_{18} \mathrm{H}_{17}{ }^{35} \mathrm{Cl}_{2} \mathrm{NO}_{4} \mathrm{Na}$ requires 404.0432 . 
4-(4-Bromophenyl)-3-chloro-1-(3,4,5-trimethoxyphenyl)azetidin-2-one (10c)

Compound 10c was prepared as described in the general method II above from imine 9c and chloroacetyl chloride; yield: 9\%, $192 \mathrm{mg}$, brown oil (HPLC: 97.5\%). IR ( $\mathrm{NaCl}$, film) $\mathrm{V}_{\text {max }}$ : 2606, 2499, 1766 (C=O, $\beta$-lactam), 1591, 1506, 1235, $1128 \mathrm{~cm}^{-1} .{ }^{1} \mathrm{H}$ NMR $(400 \mathrm{MHz}$, $\left.\mathrm{CDCl}_{3}\right): \delta 3.74\left(\mathrm{~s}, 6 \mathrm{H}, \mathrm{OCH}_{3}\right), 3.79\left(\mathrm{~s}, 3 \mathrm{H}, \mathrm{OCH}_{3}\right), 4.61\left(\mathrm{br} \mathrm{s}, 1 \mathrm{H}, \mathrm{H}_{4}\right), 4.97\left(\mathrm{br} \mathrm{s}, 1 \mathrm{H}, \mathrm{H}_{3}\right)$, $6.51\left(\mathrm{~s}, 2 \mathrm{H}, \mathrm{H}_{2^{\prime}} \mathrm{H}_{6^{\prime}}\right), 7.29\left(\mathrm{~d}, J=8.52 \mathrm{~Hz}, 2 \mathrm{H}, \mathrm{H}_{2^{\prime}}{ }^{\prime} \mathrm{H}_{6^{\prime}}{ }^{\prime}\right), 7.59\left(\mathrm{~d}, J=8.56 \mathrm{~Hz}, 2 \mathrm{H}, \mathrm{H}_{3^{\prime}}{ }^{\prime} \mathrm{H}_{5^{\prime}}{ }^{\prime}\right)$. ${ }^{13} \mathrm{C}$ NMR $\left(100 \mathrm{MHz}, \mathrm{CDCl}_{3}\right): \delta 55.67,60.52\left(\mathrm{OCH}_{3}\right), 62.49\left(\mathrm{C}_{3}\right), 65.23\left(\mathrm{C}_{4}\right), 94.72\left(\mathrm{C}_{2^{\prime}}, \mathrm{C}_{6^{\prime}}\right)$, $123.25\left(\mathrm{C}_{4^{\prime}}{ }^{\prime}\right), 127.28\left(\mathrm{C}_{2^{\prime}}{ }^{\prime}, \mathrm{C}_{6^{\prime}}{ }^{\prime}\right), 132.17\left(\mathrm{C}_{4^{\prime}}\right), 132.29\left(\mathrm{C}_{3^{\prime}}{ }^{\prime}, \mathrm{C}_{5^{\prime}}{ }^{\prime}\right), 133.57\left(\mathrm{C}_{1^{\prime}}\right), 134.87\left(\mathrm{C}_{1^{\prime}}{ }^{\prime}\right)$, $153.20\left(\mathrm{C}_{3^{\prime}}, \mathrm{C}_{5^{\prime}}\right), 159.83\left(\mathrm{C}_{2}\right)$. HRMS: found $447.9915[\mathrm{M}+\mathrm{Na}]^{+} ; \mathrm{C}_{18} \mathrm{H}_{17}{ }^{80} \mathrm{Br}^{35} \mathrm{ClNO}_{4} \mathrm{Na}$ requires 447.9927 .

3-Chloro-1-(3,4,5-trimethoxyphenyl)-4-(4-nitrophenyl)azetidin-2-one (10d)

Compound $10 \mathrm{~d}$ was prepared as described in the general method II above from imine 9d and chloroacetyl chloride; yield: 7\%, $142 \mathrm{mg}$, yellow oil (HPLC: 97.5\%). IR ( $\mathrm{NaCl}$, film) $\mathrm{V}_{\text {max }}$ : 2606, 2499, 1768 (C=O, $\beta$-lactam), 1603, 1507, 1235, $1128 \mathrm{~cm}^{-1} .{ }^{1} \mathrm{H}$ NMR $(400 \mathrm{MHz}$, $\left.\mathrm{CDCl}_{3}\right): \delta 3.74\left(\mathrm{~s}, 6 \mathrm{H}, \mathrm{OCH}_{3}\right), 3.79\left(\mathrm{~s}, 3 \mathrm{H}, \mathrm{OCH}_{3}\right), 4.65\left(\mathrm{~d}, J=2.00 \mathrm{~Hz}, 1 \mathrm{H}, \mathrm{H}_{4}\right), 5.13(\mathrm{br} \mathrm{s}$, $\left.1 \mathrm{H}, \mathrm{H}_{3}\right), 6.49\left(\mathrm{~s}, 2 \mathrm{H}, \mathrm{H}_{2^{\prime}} \mathrm{H}_{6^{\prime}}\right), 7.61\left(\mathrm{~d}, J=8.52 \mathrm{~Hz}, 2 \mathrm{H}, \mathrm{H}_{2^{\prime}} \mathrm{H}_{6^{\prime}}{ }^{\prime}\right), 8.33(\mathrm{~d}, J=9.04 \mathrm{~Hz}, 2 \mathrm{H}$, $\left.\mathrm{H}_{3^{\prime}}{ }^{\prime} \mathrm{H}_{5^{\prime}}{ }^{\prime}\right) .{ }^{13} \mathrm{C}$ NMR $\left(100 \mathrm{MHz}, \mathrm{CDCl}_{3}\right): \delta 55.73,60.54\left(\mathrm{OCH}_{3}\right), 62.42\left(\mathrm{C}_{3}\right), 64.71\left(\mathrm{C}_{4}\right), 94.72$ $\left(\mathrm{C}_{2^{\prime}}, \mathrm{C}_{6^{\prime}}\right), 124.33\left(\mathrm{C}_{2^{\prime}}{ }^{\prime}, \mathrm{C}_{6^{\prime}}{ }^{\prime}\right), 126.64\left(\mathrm{C}_{3^{\prime}}{ }^{\prime}, \mathrm{C}_{5^{\prime}}{ }^{\prime}\right), 131.85\left(\mathrm{C}_{4^{\prime}}\right), 135.19\left(\mathrm{C}_{1^{\prime}}\right), 141.60\left(\mathrm{C}_{4^{\prime}}{ }^{\prime}\right), 148.17$ $\left(\mathrm{C}_{1^{\prime}}{ }^{\prime}\right), 153.36\left(\mathrm{C}_{3^{\prime}}, \mathrm{C}_{5^{\prime}}\right), 159.29\left(\mathrm{C}_{2}\right)$. HRMS: found $415.0672\left[\mathrm{M}+\mathrm{Na}^{+} ; \mathrm{C}_{18} \mathrm{H}_{17}{ }^{35} \mathrm{ClN}_{2} \mathrm{O}_{6} \mathrm{Na}\right.$ requires 415.0673 .

\section{Cis-3-chloro-1-(3,4,5-trimethoxyphenyl)-4-(4-methoxyphenyl) azetidin-2-one (10e cis)}

Compound 10e cis was prepared as described in the general method II above from imine $9 e$ and chloroacetyl chloride; yield: $4 \%, 97 \mathrm{mg}$, brown oil. IR ( $\mathrm{NaCl}$, film) $\mathrm{V}_{\max }$ : 2944, 2605, 1762 (C=O, $\beta$-lactam), 1601, 1508, 1240, $1127 \mathrm{~cm}^{-1} .{ }^{1} \mathrm{H}$ NMR (400 MHz, $\left.\mathrm{CDCl}_{3}\right)$ : $\delta 3.74\left(\mathrm{~s}, 6 \mathrm{H}, \mathrm{OCH}_{3}\right), 3.79\left(\mathrm{~s}, 3 \mathrm{H}, \mathrm{OCH}_{3}\right), 3.84\left(\mathrm{~s}, 3 \mathrm{H}, \mathrm{OCH}_{3}\right), 5.03\left(\mathrm{~d}, J=5.02 \mathrm{~Hz}, 1 \mathrm{H}, \mathrm{H}_{4}\right)$, $5.36\left(\mathrm{~d}, J=5.00 \mathrm{~Hz}, 1 \mathrm{H}, \mathrm{H}_{3}\right), 6.57\left(\mathrm{~s}, 2 \mathrm{H}, \mathrm{H}_{2^{\prime}} \mathrm{H}_{6^{\prime}}\right), 6.86\left(\mathrm{~d}, J=8.52 \mathrm{~Hz}, 2 \mathrm{H}, \mathrm{H}_{3^{\prime}}{ }^{\prime} \mathrm{H}_{5^{\prime}}{ }^{\prime}\right), 7.03$ $\left(\mathrm{d}, J=9.04 \mathrm{~Hz}, 2 \mathrm{H}, \mathrm{H}_{2^{\prime}}{ }^{\prime} \mathrm{H}_{6^{\prime}}{ }^{\prime}\right) .{ }^{13} \mathrm{C}$ NMR $\left(100 \mathrm{MHz}, \mathrm{CDCl}_{3}\right): \delta 54.75,55.16,60.21\left(\mathrm{OCH}_{3}\right)$, $60.73\left(\mathrm{C}_{3}\right), 63.66\left(\mathrm{C}_{4}\right), 94.75\left(\mathrm{C}_{2^{\prime}}, \mathrm{C}_{6^{\prime}}\right), 113.78\left(\mathrm{C}_{3^{\prime}}{ }^{\prime}, \mathrm{C}_{5^{\prime}}{ }^{\prime}\right), 126.09\left(\mathrm{C}_{2^{\prime}}{ }^{\prime}, \mathrm{C}_{6^{\prime}}{ }^{\prime}\right), 131.51\left(\mathrm{C}_{4^{\prime}}\right)$, $131.90\left(\mathrm{C}_{1^{\prime}}{ }^{\prime}\right), 134.31\left(\mathrm{C}_{1^{\prime}}\right), 153.06\left(\mathrm{C}_{3^{\prime}}, \mathrm{C}_{5^{\prime}}\right), 159.95\left(\mathrm{C}_{4^{\prime}}{ }^{\prime}\right), 161.01\left(\mathrm{C}_{2}\right)$. HRMS: found 578.1107 $[\mathrm{M}+\mathrm{H}]^{+} ; \mathrm{C}_{19} \mathrm{H}_{21}{ }^{35} \mathrm{ClNO}_{5}$ requires 378.1108 .

Trans-3-chloro-1-(3,4,5-trimethoxyphenyl)-4-(4-methoxyphenyl) azetidin-2-one (10e trans)

Compound 10e trans was also isolated as described in the general method II above from imine 9e and chloroacetyl chloride; yield: $8 \%, 181 \mathrm{mg}$, brown oil [74]. IR ( $\mathrm{NaCl}$, film) $\mathrm{V}_{\text {max }}$ : 2954, 2603, 1772 (C=O, $\beta$-lactam), 1681, 1507, 1235, $1126 \mathrm{~cm}^{-1} .{ }^{1} \mathrm{H}$ NMR $(400 \mathrm{MHz}$, $\left.\mathrm{CDCl}_{3}\right): \delta 3.72\left(\mathrm{~s}, 6 \mathrm{H}, \mathrm{OCH}_{3}\right), 3.78\left(\mathrm{~s}, 3 \mathrm{H}, \mathrm{OCH}_{3}\right), 3.84\left(\mathrm{~s}, 3 \mathrm{H}, \mathrm{OCH}_{3}\right), 4.63(\mathrm{~d}, J=2.00 \mathrm{~Hz}$, $\left.1 \mathrm{H}, \mathrm{H}_{4}\right), 4.95\left(\mathrm{~d}, J=2.00 \mathrm{~Hz}, 1 \mathrm{H}, \mathrm{H}_{3}\right), 6.54\left(\mathrm{~s}, 2 \mathrm{H}, \mathrm{H}_{2^{\prime}} \mathrm{H}_{6^{\prime}}\right), 6.96\left(\mathrm{~d}, J=8.52 \mathrm{~Hz}, 2 \mathrm{H}, \mathrm{H}_{3^{\prime}}\right.$ $\left.\mathrm{H}_{5^{\prime}}{ }^{\prime}\right), 7.33\left(\mathrm{~d}, J=9.04 \mathrm{~Hz}, 2 \mathrm{H}, \mathrm{H}_{2^{\prime}}{ }^{\prime} \mathrm{H}_{6^{\prime}}{ }^{\prime}\right) .{ }^{13} \mathrm{C} \mathrm{NMR}\left(100 \mathrm{MHz}, \mathrm{CDCl}_{3}\right): \delta 54.95,55.60,60.51$ $\left(\mathrm{OCH}_{3}\right), 62.73\left(\mathrm{C}_{3}\right), 65.66\left(\mathrm{C}_{4}\right), 94.78\left(\mathrm{C}_{2^{\prime}}, \mathrm{C}_{6^{\prime}}\right), 114.38\left(\mathrm{C}_{3^{\prime}}{ }^{\prime}, \mathrm{C}_{5^{\prime}}{ }^{\prime}\right), 127.09\left(\mathrm{C}_{2^{\prime}}{ }^{\prime}, \mathrm{C}_{6^{\prime}}{ }^{\prime}\right), 131.56$ $\left(\mathrm{C}_{4^{\prime}}\right), 132.50\left(\mathrm{C}_{1^{\prime}}{ }^{\prime}\right), 134.61\left(\mathrm{C}_{1^{\prime}}\right), 153.08\left(\mathrm{C}_{3^{\prime}}, \mathrm{C}_{5^{\prime}}\right), 160.05\left(\mathrm{C}_{4^{\prime}}{ }^{\prime}\right), 160.29\left(\mathrm{C}_{2}\right)$. HRMS: found $378.1104[\mathrm{M}+\mathrm{H}]^{+} ; \mathrm{C}_{19} \mathrm{H}_{21}{ }^{35} \mathrm{ClNO}_{5}$ requires 378.1108.

3-Chloro-1-(3,4,5-trimethoxyphenyl)-4-(4-phenoxyphenyl)azetidin-2-one (10g)

Compound $10 \mathrm{~g}$ was prepared as described in the general method II above from imine 9g and chloroacetyl chloride; yield: $8 \%, 178 \mathrm{mg}$, brown oil. IR ( $\mathrm{NaCl}$, film) $\mathrm{V}_{\max }$ : 2982, 2682, 1764 (C=O, $\beta$-lactam), 1692, 1585, 1506, $1127 \mathrm{~cm}^{-1} .{ }^{1} \mathrm{H}$ NMR $\left(400 \mathrm{MHz}, \mathrm{CDCl}_{3}\right): \delta 3.75$ $\left(\mathrm{s}, 6 \mathrm{H}, \mathrm{OCH}_{3}\right), 3.80\left(\mathrm{~s}, 3 \mathrm{H}, \mathrm{OCH}_{3}\right), 4.66\left(\mathrm{~d}, J=1.52 \mathrm{~Hz}, 1 \mathrm{H}, \mathrm{H}_{4}\right), 4.98\left(\mathrm{br} \mathrm{s}, 1 \mathrm{H}, \mathrm{H}_{3}\right), 6.55(\mathrm{~s}, 2 \mathrm{H}$, $\left.\mathrm{H}_{2^{\prime}} \mathrm{H}_{6^{\prime}}\right), 7.02-7.07\left(\mathrm{~m}, 4 \mathrm{H}, \mathrm{H}_{2^{\prime}}{ }^{\prime} \mathrm{H}_{6^{\prime}}{ }^{\prime} \mathrm{H}_{2^{\prime}}{ }^{\prime \prime} \mathrm{H}_{6^{\prime}}{ }^{\prime \prime}\right), 7.16-7.20\left(\mathrm{~m}, \mathrm{H}_{4^{\prime}}{ }^{\prime \prime}\right), 7.36-7.40\left(\mathrm{~m}, 4 \mathrm{H}, \mathrm{H}_{2^{\prime}}{ }^{\prime}\right.$ $\left.\mathrm{H}_{6^{\prime}}{ }^{\prime} \mathrm{H}_{3^{\prime}}{ }^{\prime \prime} \mathrm{H}_{5^{\prime}}{ }^{\prime \prime}\right) .{ }^{13} \mathrm{C}$ NMR $\left(100 \mathrm{MHz}, \mathrm{CDCl}_{3}\right): \delta 55.63,60.53\left(\mathrm{OCH}_{3}\right), 62.69\left(\mathrm{C}_{3}\right), 65.51\left(\mathrm{C}_{4}\right)$, $94.82\left(\mathrm{C}_{2^{\prime}}, \mathrm{C}_{6^{\prime}}\right), 118.72\left(\mathrm{C}_{2^{\prime}}{ }^{\prime \prime}, \mathrm{C}_{6^{\prime}}{ }^{\prime \prime}\right), 119.00\left(\mathrm{C}_{3^{\prime}}{ }^{\prime}, \mathrm{C}_{5^{\prime}}{ }^{\prime}\right), 123.66\left(\mathrm{C}_{4^{\prime}}{ }^{\prime \prime}\right), 127.28\left(\mathrm{C}_{2^{\prime}}{ }^{\prime}, \mathrm{C}_{6^{\prime}}{ }^{\prime}\right), 128.77$ $\left(\mathrm{C}_{4^{\prime}}\right), 129.52\left(\mathrm{C}_{3^{\prime}}{ }^{\prime \prime}, \mathrm{C}_{5^{\prime}}{ }^{\prime \prime}\right), 132.40\left(\mathrm{C}_{1^{\prime}}\right), 134.73\left(\mathrm{C}_{1^{\prime}}{ }^{\prime}\right), 153.13\left(\mathrm{C}_{3^{\prime}}, \mathrm{C}_{5^{\prime}}\right), 155.76\left(\mathrm{C}_{4^{\prime}}{ }^{\prime}\right), 158.23$ $\left(\mathrm{C}_{1^{\prime}}{ }^{\prime \prime}\right), 160.14\left(\mathrm{C}_{2}\right)$. HRMS: found $462.1099[\mathrm{M}+\mathrm{Na}]^{+} ; \mathrm{C}_{24} \mathrm{H}_{22}{ }^{35} \mathrm{ClNO}_{5} \mathrm{Na}$ requires 462.1084 . 
4-(4-Benzyloxyphenyl)-3-chloro-1-(3,4,5-trimethoxyphenyl)azetidin-2-one (10h)

Compound 10h was prepared as described in the general method II above from imine $9 \mathrm{~h}$ and chloroacetyl chloride; yield: $3 \%, 70 \mathrm{mg}$, colourless solid (HPLC: 100.0\%), Mp 96-98 ${ }^{\circ} \mathrm{C}$. IR (KBr) $\mathrm{V}_{\max }$ : 2944, 1761 (C=O, $\beta$-lactam), 1597, 1508, 1237, $1127 \mathrm{~cm}^{-1}$. ${ }^{1} \mathrm{H} \mathrm{NMR}\left(400 \mathrm{MHz}, \mathrm{CDCl}_{3}\right): \delta 3.72\left(\mathrm{~s}, 6 \mathrm{H}, \mathrm{OCH}_{3}\right), 3.79\left(\mathrm{~s}, 3 \mathrm{H}, \mathrm{OCH}_{3}\right), 4.64(\mathrm{~d}, J=2.00 \mathrm{~Hz}$, $\left.1 \mathrm{H}, \mathrm{H}_{4}\right), 4.94\left(\mathrm{br} \mathrm{s}, 1 \mathrm{H}, \mathrm{H}_{3}\right), 5.10\left(\mathrm{~s}, 2 \mathrm{H}, \mathrm{OCH}_{2} \mathrm{Ar}\right), 6.54\left(\mathrm{~s}, 2 \mathrm{H}, \mathrm{H}_{2^{\prime}} \mathrm{H}_{6^{\prime}}\right), 7.02-7.05\left(\mathrm{~m}, \mathrm{H}_{3^{\prime}}\right.$ $\left.\mathrm{H}_{5^{\prime}}{ }^{\prime}\right)$, 7.28-7.45 (m, 7H, $\left.\mathrm{H}_{2^{\prime}}{ }^{\prime} \mathrm{H}_{6^{\prime}} \mathrm{H}_{2^{\prime}}{ }^{\prime \prime} \mathrm{H}_{3^{\prime}}{ }^{\prime \prime} \mathrm{H}_{4^{\prime}}{ }^{\prime \prime} \mathrm{H}_{5^{\prime}}{ }^{\prime \prime} \mathrm{H}_{6^{\prime}}{ }^{\prime \prime}\right) .{ }^{13} \mathrm{C} \mathrm{NMR}\left(100 \mathrm{MHz}, \mathrm{CDCl}_{3}\right)$ : $\delta 55.60,60.52\left(\mathrm{OCH}_{3}\right), 62.71\left(\mathrm{C}_{3}\right), 65.66\left(\mathrm{C}_{4}\right), 69.64\left(-\mathrm{OCH}_{2} \mathrm{Ar}\right), 94.79\left(\mathrm{C}_{2^{\prime}}, \mathrm{C}_{6^{\prime}}\right), 115.32\left(\mathrm{C}_{3^{\prime}}{ }^{\prime}\right.$, $\left.\mathrm{C}_{5^{\prime}}{ }^{\prime}\right), 126.62\left(\mathrm{C}_{4^{\prime}}\right), 126.99\left(\mathrm{C}_{2^{\prime}}{ }^{\prime}, \mathrm{C}_{6^{\prime}}{ }^{\prime}\right), 127.12\left(\mathrm{C}_{2^{\prime}}{ }^{\prime \prime}, \mathrm{C}_{6^{\prime}}{ }^{\prime \prime}\right), 127.74\left(\mathrm{C}_{4^{\prime \prime}}{ }^{\prime \prime}\right), 128.22\left(\mathrm{C}_{3^{\prime}}{ }^{\prime \prime}, \mathrm{C}_{5^{\prime}}{ }^{\prime \prime}\right)$, $132.50\left(\mathrm{C}_{1^{\prime}}{ }^{\prime}\right), 134.62\left(\mathrm{C}_{1^{\prime}}\right), 135.93\left(\mathrm{C}_{1^{\prime}}{ }^{\prime \prime}\right), 153.08\left(\mathrm{C}_{3^{\prime}}, \mathrm{C}_{5^{\prime}}\right), 159.17\left(\mathrm{C}_{4^{\prime}}{ }^{\prime}\right), 160.27\left(\mathrm{C}_{2}\right)$. HRMS: found $476.1233[\mathrm{M}+\mathrm{Na}]^{+} ; \mathrm{C}_{25} \mathrm{H}_{24}{ }^{35} \mathrm{ClNO}_{5} \mathrm{Na}$ requires 476.1241.

3-Chloro-1-(3,4,5-trimethoxyphenyl)-4-(naphthalen-1-yl)azetidin-2-one (10j)

Compound $10 \mathbf{j}$ was prepared as described in the general method II above from imine 9j and chloroacetyl chloride; yield: $12 \%, 244 \mathrm{mg}$, brown oil (HPLC: $95.5 \%)$. IR ( $\mathrm{NaCl}$, film) $\mathrm{V}_{\text {max }}$ : 2604, 2498, 1763 (C=O, $\beta$-lactam), 1597, 1506, 1235, $1126 \mathrm{~cm}^{-1} .{ }^{1} \mathrm{H}$ NMR $(400 \mathrm{MHz}$, $\left.\mathrm{CDCl}_{3}\right): \delta 3.71\left(\mathrm{~s}, 6 \mathrm{H}, \mathrm{OCH}_{3}\right), 3.82\left(\mathrm{~s}, 3 \mathrm{H}, \mathrm{OCH}_{3}\right), 4.64\left(\mathrm{~d}, J=1.52 \mathrm{~Hz}, 1 \mathrm{H}, \mathrm{H}_{4}\right), 5.81(\mathrm{br} \mathrm{s}$, $\left.1 \mathrm{H}, \mathrm{H}_{3}\right), 6.65\left(\mathrm{~s}, 2 \mathrm{H}, \mathrm{H}_{2^{\prime}} \mathrm{H}_{6^{\prime}}\right), 7.40-8.21\left(\mathrm{~m}, 7 \mathrm{H}, \mathrm{H}_{2^{\prime}} \mathrm{H}_{3^{\prime}} \mathrm{H}_{4^{\prime}}{ }^{\prime} \mathrm{H}_{5^{\prime}}{ }^{\prime} \mathrm{H}_{6^{\prime}} \mathrm{H}_{7^{\prime}} \mathrm{H}_{8^{\prime}}{ }^{\prime}\right) .{ }^{13} \mathrm{C} \mathrm{NMR}$ $\left(100 \mathrm{MHz}, \mathrm{CDCl}_{3}\right): \delta 55.74,60.56\left(\mathrm{OCH}_{3}\right), 62.35\left(\mathrm{C}_{3}\right), 63.01\left(\mathrm{C}_{4}\right), 94.94\left(\mathrm{C}_{2^{\prime}}, \mathrm{C}_{6^{\prime}}\right), 122.22$, $122.85,124.89,126.09,126.91,128.83,129.09,129.87,132.89,133.48\left(\mathrm{C}_{4^{\prime}}\right), 133.62\left(\mathrm{C}_{1^{\prime}}\right), 134.81$ $\left(\mathrm{C}_{1^{\prime}}{ }^{\prime}\right), 153.25\left(\mathrm{C}_{3^{\prime}}, \mathrm{C}_{5^{\prime}}\right), 160.24\left(\mathrm{C}_{2}\right)$. HRMS: found $420.0992\left[\mathrm{M}+\mathrm{Na}^{+} ; \mathrm{C}_{22} \mathrm{H}_{20}{ }^{35} \mathrm{ClNO}_{4} \mathrm{Na}\right.$ requires 420.0979 .

3-Chloro-1-(3,4,5-trimethoxyphenyl)-4-(naphthalen-2-yl)azetidin-2-one (10k)

Compound 10k was prepared as described in the general method II above from imine 9k and chloroacetyl chloride; yield: 9\%, $185 \mathrm{mg}$, brown oil. IR ( $\mathrm{NaCl}$, film) $\mathrm{V}_{\max }$ : 2981, 2676, 1764 (C=O, $\beta$-lactam), 1621, 1507, 1235, $1127 \mathrm{~cm}^{-1} .{ }^{1} \mathrm{H} \mathrm{NMR}\left(400 \mathrm{MHz}, \mathrm{CDCl}_{3}\right): \delta 3.68$ $\left(\mathrm{s}, 6 \mathrm{H}, \mathrm{OCH}_{3}\right), 3.77\left(\mathrm{~s}, 3 \mathrm{H}, \mathrm{OCH}_{3}\right), 4.73\left(\mathrm{~d}, J=1.52 \mathrm{~Hz}, 1 \mathrm{H}, \mathrm{H}_{4}\right), 5.17\left(\mathrm{~d}, J=1.48 \mathrm{~Hz}, 1 \mathrm{H}, \mathrm{H}_{3}\right)$, $6.60\left(\mathrm{~s}, 2 \mathrm{H}, \mathrm{H}_{2^{\prime}} \mathrm{H}_{6^{\prime}}\right), 7.45-7.95\left(\mathrm{~m}, 7 \mathrm{H}, \mathrm{H}_{2^{\prime}}{ }^{\prime} \mathrm{H}_{3^{\prime}} \mathrm{H}_{4^{\prime}}{ }^{\prime} \mathrm{H}_{5^{\prime}} \mathrm{H}_{6^{\prime}} \mathrm{H}_{7^{\prime}}{ }^{\prime} \mathrm{H}_{8^{\prime}}\right) .{ }^{13} \mathrm{C} \mathrm{NMR}(100 \mathrm{MHz}$, $\left.\mathrm{CDCl}_{3}\right)$ : $\delta 55.61,60.51\left(\mathrm{OCH}_{3}\right), 62.66\left(\mathrm{C}_{3}\right), 66.13\left(\mathrm{C}_{4}\right), 94.78\left(\mathrm{C}_{2^{\prime}}, \mathrm{C}_{6^{\prime}}\right), 122.21,125.60,126.61$, $127.48,127.53,129.32,131.91,132.56,132.76\left(\mathrm{C}_{4^{\prime}}\right), 133.25\left(\mathrm{C}_{1^{\prime}}{ }^{\prime}\right), 134.72\left(\mathrm{C}_{1^{\prime}}\right), 153.14\left(\mathrm{C}_{3^{\prime}}, \mathrm{C}_{5^{\prime}}\right)$, 160.21 $\left(\mathrm{C}_{2}\right)$. HRMS: found $420.0990\left[\mathrm{M}+\mathrm{Na}^{+} ; \mathrm{C}_{22} \mathrm{H}_{20}{ }^{35} \mathrm{ClNO}_{4} \mathrm{Na}\right.$ requires 420.0979.

3-Chloro-4-(4-methoxy-3-nitrophenyl)-1-(3,4,5-trimethoxyphenyl) azetidin-2-one (10m)

Compound $10 \mathrm{~m}$ was prepared as described in the general method II above from imine 11n and chloroacetyl chloride; yield: $10 \%, 140 \mathrm{mg}$, yellow solid, Mp $93-95^{\circ} \mathrm{C}$. IR ( $\left.\mathrm{KBr}\right) \mathrm{V}_{\max }$ : 2944, 2667, 1764 (C=O, $\beta$-lactam), 1614, 1533, 1506, 1236, $1127 \mathrm{~cm}^{-1} .{ }^{1} \mathrm{H}$ NMR (400 MHz, $\left.\mathrm{CDCl}_{3}\right): \delta 3.76\left(\mathrm{~s}, 6 \mathrm{H}, \mathrm{OCH}_{3}\right), 3.79\left(\mathrm{~s}, 3 \mathrm{H}, \mathrm{OCH}_{3}\right), 4.00\left(\mathrm{~s}, 3 \mathrm{H}, \mathrm{OCH}_{3}\right), 4.64(\mathrm{~d}, J=2.00 \mathrm{~Hz}$, $\left.1 \mathrm{H}, \mathrm{H}_{4}\right), 5.01\left(\mathrm{~d}, J=1.48 \mathrm{~Hz}, 1 \mathrm{H}, \mathrm{H}_{3}\right), 6.51\left(\mathrm{~s}, 2 \mathrm{H}, \mathrm{H}_{2^{\prime}} \mathrm{H}_{6^{\prime}}\right), 7.16-7.19\left(\mathrm{~m}, 1 \mathrm{H}, \mathrm{H}_{2^{\prime}}{ }^{\prime}\right)$, 7.55-7.58 $\left(\mathrm{m}, 1 \mathrm{H}, \mathrm{H}_{6^{\prime}}{ }^{\prime}\right), 7.93\left(\mathrm{~d}, J=2.00 \mathrm{~Hz}, 1 \mathrm{H}, \mathrm{H}_{5^{\prime}}{ }^{\prime}\right) .{ }^{13} \mathrm{C} \mathrm{NMR}\left(100 \mathrm{MHz}, \mathrm{CDCl}_{3}\right): \delta 55.71,55.75$, $60.53\left(\mathrm{OCH}_{3}\right), 62.47\left(\mathrm{C}_{3}\right), 64.37\left(\mathrm{C}_{4}\right), 94.37\left(\mathrm{C}_{2^{\prime}}, \mathrm{C}_{6^{\prime}}\right), 114.27\left(\mathrm{C}_{5^{\prime}}{ }^{\prime}\right), 123.41\left(\mathrm{C}_{2^{\prime}}{ }^{\prime}\right), 126.78\left(\mathrm{C}_{4^{\prime}}\right)$, $130.93\left(\mathrm{C}_{6^{\prime}}{ }^{\prime}\right), 131.88\left(\mathrm{C}_{1^{\prime}}\right), 132.25\left(\mathrm{C}_{1^{\prime}}{ }^{\prime}\right), 134.87\left(\mathrm{C}_{3^{\prime}}{ }^{\prime}\right), 152.95\left(\mathrm{C}_{3^{\prime}}, \mathrm{C}_{5^{\prime}}\right), 153.32\left(\mathrm{C}_{4^{\prime}}{ }^{\prime}\right), 163.30$ $\left(\mathrm{C}_{2}\right)$. HRMS: found $445.0777[\mathrm{M}+\mathrm{Na}]^{+} ; \mathrm{C}_{19} \mathrm{H}_{19}{ }^{35} \mathrm{ClN}_{2} \mathrm{O}_{7} \mathrm{Na}$ requires 445.0778.

3-Chloro-4-(3-hydroxy-4-methoxy-phenyl)-1-(3,4,5-trimethoxyphenyl)azetidin-2-one (10n)

A solution of the chloroacetic acid $(1 \mathrm{mmol})$ and triphosgene $(0.5 \mathrm{mmol})$ in dry DCM $(10 \mathrm{~mL})$ was refluxed under $\mathrm{N}_{2}$. After $30 \mathrm{~min}$, triethylamine $(1.5 \mathrm{mmol}, 0.21 \mathrm{~mL})$ was added, followed by the dropwise addition of the imine $9 \mathrm{~m}(0.5 \mathrm{mmol})$ dissolved in dry DCM $(15 \mathrm{~mL})$ over $30 \mathrm{~min}$. The reaction mixture was heated at reflux for a further $6 \mathrm{~h}$ and then cooled, washed with water $(20 \mathrm{~mL})$ and saturated $\mathrm{NaHCO}_{3}(2 \times 20 \mathrm{~mL})$ and brine $(10 \mathrm{~mL})$. The solution was then dried over anhydrous sodium sulfate and the solvent was removed under reduced pressure. The product $\mathbf{1 0 1}$ was isolated using flash column chromatography over silica gel. To a stirring solution of the protected $\beta$-lactam product $101(5 \mathrm{mmol})$, under $\mathrm{N}_{2}$ and $0{ }^{\circ} \mathrm{C}$ in dry conditions, THF was added dropwise in 1.5 equivalents of a 
1.0 M tert-butylammonium fluoride ( $t$-BAF) solution in hexanes $(5 \mathrm{mmol})$. The resulting solution was stirred at $0{ }^{\circ} \mathrm{C}$ until the reaction was completed by TLC, then diluted with ethyl acetate $(75 \mathrm{~mL})$, washed with $0.1 \mathrm{M} \mathrm{HCl}(100 \mathrm{~mL})$ and extracted with ethyl acetate $(2 \times 25 \mathrm{~mL})$. All organic layers were washed with $\mathrm{H}_{2} \mathrm{O}(100 \mathrm{~mL})$, and saturated brine $(100 \mathrm{~mL})$, then dried over anhydrous sodium sulphate. The solvent was removed under reduced pressure to yield the product that was purified using flash chromatography over silica gel (eluent, 4:1 $n$-hexane: ethyl acetate). Yield: $34 \%, 668 \mathrm{mg}$, brown oil. IR ( $\mathrm{NaCl}$ film $\left.\mathrm{V}_{\text {max }}\right): 1770 \mathrm{~cm}^{-1}(\mathrm{C}=\mathrm{O}), 3417 \mathrm{~cm}^{-1}(\mathrm{OH}) .{ }^{1} \mathrm{H}$ NMR $\left(400 \mathrm{MHz}, \mathrm{CDCl}_{3}\right): \delta 3.74(\mathrm{~s}, 6 \mathrm{H}$, $\left.\mathrm{OCH}_{3}\right), 3.78\left(\mathrm{~s}, 3 \mathrm{H}, \mathrm{OCH}_{3}\right), 3.92\left(\mathrm{~s}, 3 \mathrm{H}, \mathrm{OCH}_{3}\right), 4.61\left(\mathrm{~d}, 1 \mathrm{H}, \mathrm{H}_{4}\right), 4.89\left(\mathrm{~d}, J_{3,4}=1.52 \mathrm{~Hz}, 1 \mathrm{H}\right.$, $\left.\mathrm{H}_{3}\right), 5.81(\mathrm{~s}, 1 \mathrm{H}, \mathrm{OH}), 6.56\left(\mathrm{~s}, 2 \mathrm{H}, \mathrm{H}_{2^{\prime}}, \mathrm{H}_{6^{\prime}}\right), 6.87-6.95\left(\mathrm{~m}, 3 \mathrm{H}, \mathrm{H}_{2^{\prime}}{ }^{\prime}, \mathrm{H}_{5^{\prime}}{ }^{\prime}, \mathrm{H}_{6^{\prime}}{ }^{\prime}\right) .{ }^{13} \mathrm{C}$ NMR $\left(100 \mathrm{MHz}, \mathrm{CDCl}_{3}\right): \delta 55.59,55.63,60.51\left(\mathrm{OCH}_{3}\right), 62.67\left(\mathrm{C}_{3}\right), 65.63\left(\mathrm{C}_{4}\right), 94.81\left(\mathrm{C}_{2^{\prime}}, \mathrm{C}_{6^{\prime}}\right), 110.61$ $\left(\mathrm{C}_{2^{\prime}}{ }^{\prime}\right), 111.58\left(\mathrm{C}_{5^{\prime}}{ }^{\prime}\right), 117.72\left(\mathrm{C}_{6^{\prime}}{ }^{\prime}\right), 127.52\left(\mathrm{C}_{4^{\prime}}\right), 132.50\left(\mathrm{C}_{1^{\prime}}\right), 134.63\left(\mathrm{C}_{1^{\prime}}{ }^{\prime}\right), 146.04\left(\mathrm{C}_{3^{\prime}}{ }^{\prime}\right), 147.00$ $\left(\mathrm{C}_{4^{\prime}}\right), 153.08\left(\mathrm{C}_{3^{\prime}}, \mathrm{C}_{5^{\prime}}\right), 160.22\left(\mathrm{C}_{2}\right)$. HRMS: found $416.0897\left[\mathrm{M}+\mathrm{Na}^{+} ; \mathrm{C}_{19} \mathrm{H}_{21} \mathrm{ClNO}_{6} \mathrm{Na}\right.$ requires 416.0877 .

\section{3,3-Dichloro-1-(3,4,5-trimethoxyphenyl)-4-phenylazetidin-2-one (11a)}

Compound 11a was prepared as described in the general method II above from imine 9a and dichloroacetyl chloride; yield: 31\%, $597 \mathrm{mg}$, yellow solid, Mp 80-81 ${ }^{\circ} \mathrm{C}$ (HPLC: 100.0\%). IR (KBr) $\mathrm{V}_{\max }$ : 2943, 2605, 2498, 1780 (C=O, $\beta$-lactam), 1594, 1506, 1239, $1127 \mathrm{~cm}^{-1}$. ${ }^{1} \mathrm{H}$ NMR $\left(400 \mathrm{MHz}, \mathrm{CDCl}_{3}\right): \delta 3.72\left(\mathrm{~s}, 6 \mathrm{H}, \mathrm{OCH}_{3}\right), 3.80\left(\mathrm{~s}, 3 \mathrm{H}, \mathrm{OCH}_{3}\right), 5.50\left(\mathrm{~s}, 1 \mathrm{H}, \mathrm{H}_{4}\right), 6.55$ (s, 2H, $\left.\mathrm{H}_{2^{\prime}} \mathrm{H}_{6^{\prime}}\right)$, 7.35-7.47 (m, 5H, $\left.\mathrm{H}_{2^{\prime}}{ }^{\prime} \mathrm{H}_{3^{\prime}}{ }^{\prime} \mathrm{H}_{4^{\prime}} \mathrm{H}_{5^{\prime}} \mathrm{H}_{6^{\prime}}{ }^{\prime}\right) .{ }^{13} \mathrm{C} \mathrm{NMR}\left(100 \mathrm{MHz}, \mathrm{CDCl}_{3}\right)$ :

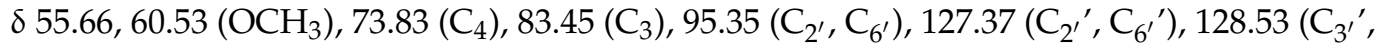
$\left.\mathrm{C}_{5^{\prime}}{ }^{\prime}\right), 129.61\left(\mathrm{C}_{4^{\prime}}{ }^{\prime}\right), 131.07\left(\mathrm{C}_{4^{\prime}}\right), 131.40\left(\mathrm{C}_{1^{\prime}}\right), 135.22\left(\mathrm{C}_{1^{\prime}}{ }^{\prime}\right), 153.19\left(\mathrm{C}_{3^{\prime}}, \mathrm{C}_{5^{\prime}}\right), 157.82\left(\mathrm{C}_{2}\right)$. HRMS: found $404.0433[\mathrm{M}+\mathrm{Na}]^{+} ; \mathrm{C}_{18} \mathrm{H}_{17}{ }^{35} \mathrm{Cl}_{2} \mathrm{NO}_{4} \mathrm{Na}$ requires 404.0432 .

\section{3,3-Dichloro-4-(4-chlorophenyl)-1-(3,4,5-trimethoxyphenyl)azetidin-2-one (11b)}

Compound $\mathbf{1 1 b}$ was prepared as described in the general method II above from imine 9b and dichloroacetyl chloride; yield: $31 \%, 635 \mathrm{mg}$, brown solid, Mp 150-153 ${ }^{\circ} \mathrm{C}$ (HPLC: 99.7\%). IR (KBr) V $\mathrm{V}_{\text {max }}$ : 2942, 2605, 2498, 1781 (C=O, $\beta$-lactam), 1594, 1506, 1238, $1123 \mathrm{~cm}^{-1}$. ${ }^{1} \mathrm{H} \mathrm{NMR}\left(400 \mathrm{MHz}, \mathrm{CDCl}_{3}\right): \delta 3.74\left(\mathrm{~s}, 6 \mathrm{H}, \mathrm{OCH}_{3}\right), 3.81\left(\mathrm{~s}, 3 \mathrm{H}, \mathrm{OCH}_{3}\right), 5.48\left(\mathrm{~s}, 1 \mathrm{H}, \mathrm{H}_{4}\right)$, $6.53\left(\mathrm{~s}, 2 \mathrm{H}, \mathrm{H}_{2^{\prime}} \mathrm{H}_{6^{\prime}}\right), 7.30\left(\mathrm{~d}, J=8.56 \mathrm{~Hz}, 2 \mathrm{H}, \mathrm{H}_{3^{\prime}}{ }^{\prime} \mathrm{H}_{5^{\prime}}{ }^{\prime}\right), 7.45\left(\mathrm{~d}, J=8.52 \mathrm{~Hz}, 2 \mathrm{H}, \mathrm{H}_{2^{\prime}}\right.$ $\left.\mathrm{H}_{6^{\prime}}{ }^{\prime}\right) .{ }^{13} \mathrm{C}$ NMR $\left(100 \mathrm{MHz}, \mathrm{CDCl}_{3}\right): \delta 55.74,60.55\left(\mathrm{OCH}_{3}\right), 73.08\left(\mathrm{C}_{4}\right), 83.31\left(\mathrm{C}_{3}\right), 95.30$ $\left(\mathrm{C}_{2^{\prime}}, \mathrm{C}_{6^{\prime}}\right), 128.64\left(\mathrm{C}_{2^{\prime}}{ }^{\prime}, \mathrm{C}_{6^{\prime}}{ }^{\prime}\right), 128.90\left(\mathrm{C}_{3^{\prime}}{ }^{\prime}, \mathrm{C}_{5^{\prime}}{ }^{\prime}\right), 129.69\left(\mathrm{C}_{4^{\prime}}{ }^{\prime}\right), 131.14\left(\mathrm{C}_{4^{\prime}}\right), 135.42\left(\mathrm{C}_{1^{\prime}}\right), 135.67$ $\left(\mathrm{C}_{1^{\prime}}{ }^{\prime}\right), 153.29\left(\mathrm{C}_{3^{\prime}}, \mathrm{C}_{5^{\prime}}\right), 157.58\left(\mathrm{C}_{2}\right)$. HRMS: found $438.0049[\mathrm{M}+\mathrm{Na}]^{+} ; \mathrm{C}_{18} \mathrm{H}_{16}{ }^{35} \mathrm{Cl}_{3} \mathrm{NO}_{4} \mathrm{Na}$ requires 438.0043 .

4-(4-Bromophenyl)-3,3-dichloro-1-(3,4,5-trimethoxyphenyl)azetidin-2-one (11c)

Compound 11c was prepared as described in the general method II above from imine 9c and dichloroacetyl chloride; yield: 39\%, $872 \mathrm{mg}$, yellow solid, Mp 150-152 ${ }^{\circ} \mathrm{C}$ (HPLC: 98.7\%). IR (KBr) V $\mathrm{V}_{\text {max }}: 2978,2605,2498,1782$ (C=O, $\beta$-lactam), 1592, 1506, 1240, $1128 \mathrm{~cm}^{-1}$. ${ }^{1} \mathrm{H}$ NMR $\left(400 \mathrm{MHz}, \mathrm{CDCl}_{3}\right): \delta 3.75\left(\mathrm{~s}, 6 \mathrm{H}, \mathrm{OCH}_{3}\right), 3.81\left(\mathrm{~s}, 3 \mathrm{H}, \mathrm{OCH}_{3}\right), 5.47\left(\mathrm{~s}, 1 \mathrm{H}, \mathrm{H}_{4}\right)$, $6.53\left(\mathrm{~s}, 2 \mathrm{H}, \mathrm{H}_{2^{\prime}} \mathrm{H}_{6^{\prime}}\right), 7.24\left(\mathrm{~d}, J=8.00 \mathrm{~Hz}, 2 \mathrm{H}, \mathrm{H}_{2^{\prime}}{ }^{\prime} \mathrm{H}_{6^{\prime}}{ }^{\prime}\right), 7.61\left(\mathrm{~d}, J=7.52 \mathrm{~Hz}, 2 \mathrm{H}, \mathrm{H}_{3^{\prime}}{ }^{\prime} \mathrm{H}_{5^{\prime}}{ }^{\prime}\right)$. ${ }^{13} \mathrm{C}$ NMR $\left(100 \mathrm{MHz}, \mathrm{CDCl}_{3}\right): \delta 55.75,60.56\left(\mathrm{OCH}_{3}\right), 73.13\left(\mathrm{C}_{4}\right), 83.20\left(\mathrm{C}_{3}\right), 95.29\left(\mathrm{C}_{2^{\prime}}, \mathrm{C}_{6^{\prime}}\right)$, $123.88\left(\mathrm{C}_{4^{\prime}}{ }^{\prime}\right), 128.88\left(\mathrm{C}_{2^{\prime}}, \mathrm{C}_{6^{\prime}}{ }^{\prime}\right), 130.21\left(\mathrm{C}_{4^{\prime}}\right), 131.13\left(\mathrm{C}_{1^{\prime}}\right), 131.85\left(\mathrm{C}_{3^{\prime}}, \mathrm{C}_{5^{\prime}}\right), 135.42\left(\mathrm{C}_{1^{\prime}}{ }^{\prime}\right)$, $153.29\left(\mathrm{C}_{3^{\prime}}, \mathrm{C}_{5^{\prime}}\right), 157.57\left(\mathrm{C}_{2}\right)$. HRMS: found $481.9561[\mathrm{M}+\mathrm{Na}]^{+} ; \mathrm{C}_{18} \mathrm{H}_{16}{ }^{80} \mathrm{Br}^{35} \mathrm{Cl}_{2} \mathrm{NO}_{4} \mathrm{Na}$ requires 481.9537 .

\section{3,3-Dichloro-1-(3,4,5-trimethoxyphenyl)-4-(4-nitrophenyl)azetidin-2-one (11d)}

Compound 11d was prepared as described in the general method II above from imine 9d and dichloroacetyl chloride; yield: $44 \%$, $932 \mathrm{mg}$, yellow solid, Mp 116-118 ${ }^{\circ} \mathrm{C}$ (HPLC: 95.5\%). IR (KBr) V $V_{\max }: 2944,2605,2498,1784$ (C=O, $\beta$-lactam), 1596, 1506, 1346, $1127 \mathrm{~cm}^{-1}$. ${ }^{1} \mathrm{H}$ NMR $\left(400 \mathrm{MHz}, \mathrm{CDCl}_{3}\right): \delta 3.75\left(\mathrm{~s}, 6 \mathrm{H}, \mathrm{OCH}_{3}\right), 3.81\left(\mathrm{~s}, 3 \mathrm{H}, \mathrm{OCH}_{3}\right), 5.62\left(\mathrm{~s}, 1 \mathrm{H}, \mathrm{H}_{4}\right)$, $6.51\left(\mathrm{~s}, 2 \mathrm{H}, \mathrm{H}_{2^{\prime}} \mathrm{H}_{6^{\prime}}\right), 7.56\left(\mathrm{~d}, J=7.52 \mathrm{~Hz}, 2 \mathrm{H}, \mathrm{H}_{2^{\prime}}{ }^{\prime} \mathrm{H}_{6^{\prime}}{ }^{\prime}\right), 8.34\left(\mathrm{~d}, J=8.52 \mathrm{~Hz}, 2 \mathrm{H}, \mathrm{H}_{3^{\prime}}{ }^{\prime} \mathrm{H}_{5^{\prime}}{ }^{\prime}\right)$. ${ }^{13} \mathrm{C}$ NMR $\left(100 \mathrm{MHz}, \mathrm{CDCl}_{3}\right): \delta 55.80,60.55\left(\mathrm{OCH}_{3}\right), 72.52\left(\mathrm{C}_{4}\right), 83.02\left(\mathrm{C}_{3}\right), 95.26\left(\mathrm{C}_{2^{\prime}}, \mathrm{C}_{6^{\prime}}\right)$, 
$123.81\left(\mathrm{C}_{2^{\prime}}{ }^{\prime}, \mathrm{C}_{6^{\prime}}{ }^{\prime}\right), 128.29\left(\mathrm{C}_{3^{\prime}}{ }^{\prime}, \mathrm{C}_{5^{\prime}}{ }^{\prime}\right), 130.80\left(\mathrm{C}_{4^{\prime}}\right), 135.74\left(\mathrm{C}_{1^{\prime}}\right), 138.21\left(\mathrm{C}_{4^{\prime}}{ }^{\prime}\right), 148.42\left(\mathrm{C}_{1^{\prime}}{ }^{\prime}\right)$, $153.45\left(\mathrm{C}_{3^{\prime}}, \mathrm{C}_{5^{\prime}}\right), 157.10\left(\mathrm{C}_{2}\right)$. HRMS: found $449.0272[\mathrm{M}+\mathrm{Na}]^{+} ; \mathrm{C}_{18} \mathrm{H}_{16}{ }^{35} \mathrm{Cl}_{2} \mathrm{~N}_{2} \mathrm{O}_{6} \mathrm{Na}$ requires 449.0283 .

3,3-Dichloro-1-(3,4,5-trimethoxyphenyl)-4-(4-phenoxyphenyl)azetidin-2-one (11g)

Compound 11g was prepared as described in the general method II above from imine $9 \mathrm{~g}$ and dichloroacetyl chloride; yield: $24 \%, 576 \mathrm{mg}$, grey solid (HPLC: $99.8 \%$ ). Mp. $82-84{ }^{\circ} \mathrm{C}$. IR (KBr) $\mathrm{V}_{\max }: 2942,1779$ (C=O, $\beta$-lactam), 1697, 1588, 1506, 1230, $1128 \mathrm{~cm}^{-1} .{ }^{1} \mathrm{H}$ NMR (400 MHz, CDCl 3 ): $\delta 3.75\left(\mathrm{~s}, 6 \mathrm{H}, \mathrm{OCH}_{3}\right), 3.81\left(\mathrm{~s}, 3 \mathrm{H}, \mathrm{OCH}_{3}\right), 5.48\left(\mathrm{~s}, 1 \mathrm{H}, \mathrm{H}_{4}\right), 6.56$ (s, 2H, $\left.\mathrm{H}_{2^{\prime}} \mathrm{H}_{6^{\prime}}\right)$, 7.05-7.07 (m, 4H, $\left.\mathrm{H}_{2^{\prime}} \mathrm{H}_{6^{\prime}} \mathrm{H}_{2^{\prime}}{ }^{\prime \prime} \mathrm{H}_{6^{\prime}}{ }^{\prime \prime}\right)$, 7.16-7.20 (m, 1H, $\left.\mathrm{H}_{4^{\prime}}{ }^{\prime \prime}\right)$, 7.30-7.41 (m, 4H, $\left.\mathrm{H}_{3^{\prime}} \mathrm{H}_{5^{\prime}}{ }^{\prime} \mathrm{H}_{3^{\prime}}{ }^{\prime \prime} \mathrm{H}_{5^{\prime}}{ }^{\prime \prime}\right) .{ }^{13} \mathrm{C}$ NMR $\left(100 \mathrm{MHz}, \mathrm{CDCl}_{3}\right): \delta 55.71,60.55\left(\mathrm{OCH}_{3}\right)$, $73.44\left(\mathrm{C}_{4}\right)$, 83.64 $\left(\mathrm{C}_{3}\right)$, $95.44\left(\mathrm{C}_{2^{\prime}}, \mathrm{C}_{6^{\prime}}\right), 117.99\left(\mathrm{C}_{2^{\prime}}{ }^{\prime \prime}, \mathrm{C}_{6^{\prime \prime}}{ }^{\prime \prime}\right), 119.20\left(\mathrm{C}_{3^{\prime}}{ }^{\prime}, \mathrm{C}_{5^{\prime}}{ }^{\prime}\right), 123.77\left(\mathrm{C}_{4^{\prime}}{ }^{\prime \prime}\right), 125.23\left(\mathrm{C}_{4^{\prime}}\right)$, $128.97\left(\mathrm{C}_{2^{\prime}}{ }^{\prime}, \mathrm{C}_{6^{\prime}}{ }^{\prime}\right), 129.53\left(\mathrm{C}_{3^{\prime}}{ }^{\prime \prime}, \mathrm{C}_{5^{\prime \prime}}{ }^{\prime \prime}\right), 131.33\left(\mathrm{C}_{1^{\prime}}\right), 135.30\left(\mathrm{C}_{1^{\prime}}{ }^{\prime}\right), 153.22\left(\mathrm{C}_{3^{\prime}}, \mathrm{C}_{5^{\prime}}\right), 155.55$ $\left(\mathrm{C}_{4^{\prime}}{ }^{\prime}\right), 157.84\left(\mathrm{C}_{1^{\prime}}{ }^{\prime \prime}\right), 158.63\left(\mathrm{C}_{2}\right)$. HRMS: found $496.0679\left[\mathrm{M}+\mathrm{Na}^{+} ; \mathrm{C}_{24} \mathrm{H}_{21}{ }^{35} \mathrm{Cl}_{2} \mathrm{NO}_{5} \mathrm{Na}\right.$ requires 496.0694 .

4-(4-Benzyloxyphenyl)-3,3-dichloro-1-(3,4,5-trimethoxyphenyl) azetidin-2-one (11h)

Compound $11 \mathrm{~h}$ was prepared as described in the general method II above from imine 9h and dichloroacetyl chloride; yield: $26 \%, 626 \mathrm{mg}$, yellow oil. IR ( $\mathrm{NaCl}$, film) $\mathrm{V}_{\text {max }}$ : 2605, 2498, 1778 (C=O, $\beta$-lactam), 1599, 1503, 1241, $1128 \mathrm{~cm}^{-1} .{ }^{1} \mathrm{H}$ NMR (400 MHz, $\left.\mathrm{CDCl}_{3}\right)$ : $\delta 3.73\left(\mathrm{~s}, 6 \mathrm{H}, \mathrm{OCH}_{3}\right), 3.81\left(\mathrm{~s}, 3 \mathrm{H}, \mathrm{OCH}_{3}\right), 5.11\left(\mathrm{~s}, 2 \mathrm{H}, \mathrm{OCH}_{2} \mathrm{Ar}\right), 5.46\left(\mathrm{~s}, 1 \mathrm{H}, \mathrm{H}_{4}\right), 6.56(\mathrm{~s}, 2 \mathrm{H}$, $\left.\mathrm{H}_{2^{\prime}} \mathrm{H}_{6^{\prime}}\right), 7.06\left(\mathrm{~d}, J=7.52 \mathrm{~Hz}, 2 \mathrm{H}, \mathrm{H}_{3^{\prime}}{ }^{\prime} \mathrm{H}_{5^{\prime}}{ }^{\prime}\right), 7.30\left(\mathrm{~d}, J=7.52 \mathrm{~Hz}, 2 \mathrm{H}, \mathrm{H}_{2^{\prime}}{ }^{\prime} \mathrm{H}_{6^{\prime}}{ }^{\prime}\right), 7.36-7.44$ $\left(\mathrm{m}, 5 \mathrm{H}, \mathrm{H}_{2^{\prime}}{ }^{\prime \prime} \mathrm{H}_{3^{\prime}}{ }^{\prime \prime} \mathrm{H}_{4^{\prime}}{ }^{\prime \prime} \mathrm{H}_{5^{\prime}}{ }^{\prime \prime} \mathrm{H}_{6^{\prime}}{ }^{\prime \prime}\right) .{ }^{13} \mathrm{C} \mathrm{NMR}\left(100 \mathrm{MHz}, \mathrm{CDCl}_{3}\right): \delta 55.69,60.53\left(\mathrm{OCH}_{3}\right)$, $69.65\left(\mathrm{OCH}_{2} \mathrm{Ar}\right), 73.60\left(\mathrm{C}_{4}\right), 83.78\left(\mathrm{C}_{3}\right), 95.41\left(\mathrm{C}_{2^{\prime}}, \mathrm{C}_{6^{\prime}}\right), 114.78\left(\mathrm{C}_{3^{\prime}}{ }^{\prime}, \mathrm{C}_{5^{\prime}}{ }^{\prime}\right), 127.04,127.11$ $\left(\mathrm{C}_{2^{\prime}}{ }^{\prime}, \mathrm{C}_{6^{\prime}}{ }^{\prime}\right), 127.77\left(\mathrm{C}_{4^{\prime}}{ }^{\prime \prime}\right), 127.73,127.77\left(\mathrm{C}_{2^{\prime}}{ }^{\prime \prime}, \mathrm{C}_{6^{\prime}}{ }^{\prime \prime}\right), 128.21,128.85\left(\mathrm{C}_{3^{\prime \prime}}{ }^{\prime \prime}, \mathrm{C}_{5^{\prime}}{ }^{\prime \prime}\right), 131.44\left(\mathrm{C}_{4^{\prime}}\right)$, $135.19\left(\mathrm{C}_{1^{\prime}}{ }^{\prime}\right), 135.90\left(\mathrm{C}_{1^{\prime}}\right), 142.69\left(\mathrm{C}_{1^{\prime \prime}}{ }^{\prime \prime}\right), 153.17\left(\mathrm{C}_{3^{\prime}}, \mathrm{C}_{5^{\prime}}\right), 157.94\left(\mathrm{C}_{4^{\prime}}{ }^{\prime}\right), 159.55\left(\mathrm{C}_{2}\right)$. HRMS: found $488.1026[\mathrm{M}+\mathrm{H}]^{+} ; \mathrm{C}_{25} \mathrm{H}_{24}{ }^{35} \mathrm{Cl}_{2} \mathrm{NO}_{5}$, requires 488.1032 .

3,3-Dichloro-1-(3,4,5-trimethoxyphenyl)-4-(naphthalen-1-yl)azetidin-2-one (11j)

Compound $11 \mathbf{j}$ was prepared as described in the general method II above from imine 9j and dichloroacetyl chloride; yield: $32 \%, 691 \mathrm{mg}$, yellow solid, Mp. $146-148{ }^{\circ} \mathrm{C}$ (HPLC: 98.4\%). IR (KBr) V $\mathrm{max}_{\max }$ 2949, 1780 (C=O, $\beta$-lactam), 2593, 1505, 1235, $1127 \mathrm{~cm}^{-1} .{ }^{1} \mathrm{H}$ NMR $\left(400 \mathrm{MHz}, \mathrm{CDCl}_{3}\right): \delta 3.73\left(\mathrm{~s}, 6 \mathrm{H}, \mathrm{OCH}_{3}\right), 3.84\left(\mathrm{~s}, 3 \mathrm{H}, \mathrm{OCH}_{3}\right), 6.25\left(\mathrm{~s}, 1 \mathrm{H}, \mathrm{H}_{4}\right), 6.66(\mathrm{~s}, 2 \mathrm{H}$, $\left.\mathrm{H}_{2^{\prime}} \mathrm{H}_{6^{\prime}}\right), 7.32-8.16\left(\mathrm{~m}, 7 \mathrm{H}, \mathrm{H}_{2^{\prime}}{ }^{\prime} \mathrm{H}_{3^{\prime}}{ }^{\prime} \mathrm{H}_{4^{\prime}}{ }^{\prime} \mathrm{H}_{5^{\prime}} \mathrm{H}_{6^{\prime}} \mathrm{H}_{7^{\prime}} \mathrm{H}_{8^{\prime}}{ }^{\prime}\right) .{ }^{13} \mathrm{C} \mathrm{NMR}\left(100 \mathrm{MHz}, \mathrm{CDCl}_{3}\right)$ : $\delta 55.84,60.58\left(\mathrm{OCH}_{3}\right), 71.19\left(\mathrm{C}_{4}\right), 83.37\left(\mathrm{C}_{3}\right), 95.53\left(\mathrm{C}_{2^{\prime}}, \mathrm{C}_{6^{\prime}}\right), 122.40,124.60,124.64,126.07$, $126.98,127.04,128.83,129.63,130.72,131.85\left(C_{4^{\prime}}\right), 133.30\left(C_{1^{\prime}}\right), 135.39\left(C_{1^{\prime}}{ }^{\prime}\right), 153.32\left(C_{3^{\prime}}, C_{5^{\prime}}\right)$, $157.99\left(\mathrm{C}_{2}\right)$. HRMS: found $454.0605[\mathrm{M}+\mathrm{Na}]^{+} ; \mathrm{C}_{22} \mathrm{H}_{19}{ }^{35} \mathrm{Cl}_{2} \mathrm{NO}_{4} \mathrm{Na}$ requires 454.0589 .

3,3-Dichloro-1-(3,4,5-trimethoxyphenyl)-4-(naphthalen-2-yl)azetidin-2-one (11k)

Compound 11k was prepared as described in the general method II above from imine 9k and dichloroacetyl chloride; yield: $35 \%$, $764 \mathrm{mg}$, yellow solid, Mp. $164-166{ }^{\circ} \mathrm{C}$ (HPLC: 96.6\%). IR (KBr) V $\mathrm{V}_{\text {max }}$ : 2983, 2693, 1779 (C=O, $\beta$-lactam), 1694, 1594, 1506, 1239, $1126 \mathrm{~cm}^{-1}$. ${ }^{1} \mathrm{H}$ NMR $\left(400 \mathrm{MHz}, \mathrm{CDCl}_{3}\right): \delta 3.70\left(\mathrm{~s}, 6 \mathrm{H}, \mathrm{OCH}_{3}\right), 3.80\left(\mathrm{~s}, 3 \mathrm{H}, \mathrm{OCH}_{3}\right), 5.68\left(\mathrm{~s}, 1 \mathrm{H}, \mathrm{H}_{4}\right)$, $6.61\left(\mathrm{~s}, 2 \mathrm{H}, \mathrm{H}_{2^{\prime}} \mathrm{H}_{6^{\prime}}\right)$, 7.41-7.59 (m, 3H, $\left.\mathrm{H}_{2^{\prime}}{ }^{\prime} \mathrm{H}_{5^{\prime}}{ }^{\prime} \mathrm{H}_{6^{\prime}}{ }^{\prime}\right), 7.89-7.95\left(\mathrm{~m}, 4 \mathrm{H}, \mathrm{H}_{3^{\prime}}{ }^{\prime} \mathrm{H}_{4^{\prime}}{ }^{\prime} \mathrm{H}_{7^{\prime}}\right.$ $\left.\mathrm{H}_{8^{\prime}}{ }^{\prime}\right) .{ }^{13} \mathrm{C}$ NMR $\left(100 \mathrm{MHz}, \mathrm{CDCl}_{3}\right): \delta 55.70,60.53\left(\mathrm{OCH}_{3}\right), 74.00\left(\mathrm{C}_{4}\right), 83.56\left(\mathrm{C}_{3}\right), 95.38$ $\left(\mathrm{C}_{2^{\prime}}, \mathrm{C}_{6^{\prime}}\right), 123.82,126.47,126.82,127.35,127.49,127.79,128.51,128.68,131.52,132.49\left(\mathrm{C}_{4^{\prime}}\right)$, $133.48\left(\mathrm{C}_{1^{\prime}}{ }^{\prime}\right), 135.30\left(\mathrm{C}_{1^{\prime}}\right), 153.25\left(\mathrm{C}_{3^{\prime}}, \mathrm{C}_{5^{\prime}}\right), 157.91\left(\mathrm{C}_{2}\right)$. HRMS: found $454.0588[\mathrm{M}+\mathrm{Na}]^{+}$; $\mathrm{C}_{22} \mathrm{H}_{19}{ }^{35} \mathrm{Cl}_{2} \mathrm{NO}_{4} \mathrm{Na}$ requires 454.0589 .

3,3-Dichloro-4-(4-methoxy-3-nitrophenyl)-1-(3,4,5-trimethoxyphenyl) azetidin-2-one (11m)

Compound $11 \mathrm{~m}$ was prepared as described in the general method II above from imine 9n and dichloroacetyl chloride; yield: $17 \%, 391 \mathrm{mg}$, colourless solid, Mp. $117-119{ }^{\circ} \mathrm{C}$. IR (KBr) $\mathrm{V}_{\max }$ : 2943, 1781 (C=O, $\beta$-lactam), 1614, 1597, 1505, 1238, $1126 \mathrm{~cm}^{-1} .{ }^{1} \mathrm{H}$ NMR $\left(400 \mathrm{MHz}, \mathrm{CDCl}_{3}\right): \delta 3.77\left(\mathrm{~s}, 6 \mathrm{H}, \mathrm{OCH}_{3}\right), 3.81\left(\mathrm{~s}, 3 \mathrm{H}, \mathrm{OCH}_{3}\right), 4.03\left(\mathrm{~s}, 3 \mathrm{H}, \mathrm{OCH}_{3}\right), 5.50(\mathrm{~s}, 1 \mathrm{H}$, 
$\left.\mathrm{H}_{4}\right), 6.53\left(\mathrm{~s}, 2 \mathrm{H}, \mathrm{H}_{2^{\prime}} \mathrm{H}_{6^{\prime}}\right), 7.19\left(\mathrm{~d}, J=9.04 \mathrm{~Hz}, 1 \mathrm{H}, \mathrm{H}_{2^{\prime}}{ }^{\prime}\right), 7.49-7.52\left(\mathrm{~m}, 1 \mathrm{H}, \mathrm{H}_{6^{\prime}}{ }^{\prime}\right), 7.92(\mathrm{~d}$, $\left.J=1.48 \mathrm{~Hz}, 1 \mathrm{H}, \mathrm{H}_{5^{\prime}}{ }^{\prime}\right) .{ }^{13} \mathrm{C} \mathrm{NMR}\left(100 \mathrm{MHz}, \mathrm{CDCl}_{3}\right): \delta 55.85,56.32,60.55\left(\mathrm{OCH}_{3}\right), 72.28$ $\left(\mathrm{C}_{4}\right), 83.44\left(\mathrm{C}_{3}\right), 95.38\left(\mathrm{C}_{2^{\prime}}, \mathrm{C}_{6^{\prime}}\right), 113.71\left(\mathrm{C}_{5^{\prime}}{ }^{\prime}\right), 123.53\left(\mathrm{C}_{4^{\prime}}\right), 124.97\left(\mathrm{C}_{2^{\prime}}{ }^{\prime}\right), 130.82\left(\mathrm{C}_{1^{\prime}}\right), 132.70$ $\left(\mathrm{C}_{6^{\prime}}{ }^{\prime}\right), 135.68\left(\mathrm{C}_{1^{\prime}}{ }^{\prime}\right), 139.12\left(\mathrm{C}_{3^{\prime}}{ }^{\prime}\right), 153.41\left(\mathrm{C}_{3^{\prime}}, \mathrm{C}_{5^{\prime}}\right), 153.62\left(\mathrm{C}_{4^{\prime}}{ }^{\prime}\right), 157.39\left(\mathrm{C}_{2}\right)$. HRMS: found $479.0367[\mathrm{M}+\mathrm{Na}]^{+} ; \mathrm{C}_{19} \mathrm{H}_{18}{ }^{35} \mathrm{Cl}_{2} \mathrm{~N}_{2} \mathrm{O}_{7} \mathrm{Na}$ requires 479.0389 .

3,3-Dichloro-4-(3-hydroxy-4-methoxyphenyl)-1-(3,4,5-trimethoxyphenyl)azetidin-2-one (11n)

(i) To a stirring, refluxing solution of the protected TBDMS imine $9 \mathrm{~m}$ (5 mmol) and triethylamine $(6 \mathrm{mmol})$ in anhydrous dichloromethane $(40 \mathrm{~mL})$, a solution of the dichloroacetyl chloride $(6 \mathrm{mmol})$ in anhydrous dichloromethane $(10 \mathrm{~mL})$ was added over $45 \mathrm{~min}$ under nitrogen. The reaction heated at reflux during the $5 \mathrm{~h}$ and retained at room temperature for $16 \mathrm{~h}$ under nitrogen, until the starting material had disappeared as monitored by TLC (eluent, 50:50 n-hexane: ethyl acetate). The reaction mixture was washed with water $(2 \times 100 \mathrm{~mL})$. The organic layer was dried over anhydrous $\mathrm{Na}_{2} \mathrm{SO}_{4}$, and the solvent was then removed under reduced pressure. The crude product was purified using flash chromatography over silica gel (eluent: $n$-hexane: ethyl acetate, 4:1) to afford the product $\mathbf{1 1 1}$ as an oil that was used immediately in the following reaction. (ii) To a stirring solution of the protected $\beta$-lactam 111 ( $5 \mathrm{mmol})$, under $\mathrm{N}_{2}$ and $0{ }^{\circ} \mathrm{C}$ in dry conditions, THF was added dropwise in 1.5 equivalents of a $1.0 \mathrm{M}$ tert-butylammonium fluoride ( $t$-BAF) solution in hexanes $(5 \mathrm{mmol})$. The resulting solution was stirred at $0{ }^{\circ} \mathrm{C}$ until reaction was complete, as verified by TLC. The reaction mixture was diluted with ethyl acetate $(75 \mathrm{~mL})$ and washed with $0.1 \mathrm{M} \mathrm{HCl}(100 \mathrm{~mL})$. The aqueous layer was further extracted with ethyl acetate $(2 \times 25 \mathrm{~mL})$. All organic layers were collected and washed with water $(100 \mathrm{~mL})$, and saturated brine $(100 \mathrm{~mL})$ and dried over an anhydrous sodium sulphate. The solvent was removed under reduced pressure to yield the product that was purified using flash chromatography over silica gel (eluent, 4:1 n-hexane: ethyl acetate). Yield: 28\%, $600 \mathrm{mg}$, colourless oil. IR (NaCl, film) $\mathrm{V}_{\text {max }}$ : $3396(\mathrm{OH}), 1782(\mathrm{C}=\mathrm{O}, \beta$-lactam), 1595, 1508, 1234, $1123 \mathrm{~cm}^{-1} .{ }^{1} \mathrm{H}$ NMR $\left(400 \mathrm{MHz}_{2} \mathrm{CDCl}_{3}\right): \delta 3.74\left(\mathrm{~s}, 6 \mathrm{H}, \mathrm{OCH}_{3}\right), 3.79\left(\mathrm{~s}, 3 \mathrm{H}, \mathrm{OCH}_{3}\right), 3.93$ $\left(\mathrm{s}, 3 \mathrm{H}, \mathrm{OCH}_{3}\right), 5.39\left(\mathrm{~s}, 1 \mathrm{H}, \mathrm{H}_{4}\right), 6.56\left(\mathrm{~s}, 2 \mathrm{H}, \mathrm{H}_{2^{\prime}} \mathrm{H}_{6^{\prime}}\right), 6.85-6.91\left(\mathrm{~m}, 3 \mathrm{H}, \mathrm{H}_{2^{\prime}}{ }^{\prime} \mathrm{H}_{5^{\prime}}{ }^{\prime} \mathrm{H}_{6^{\prime}}{ }^{\prime}\right) .{ }^{13} \mathrm{C}$ $\operatorname{NMR}\left(100 \mathrm{MHz}, \mathrm{CDCl}_{3}\right): \delta 55.51,55.70,60.52\left(\mathrm{OCH}_{3}\right), 73.54\left(\mathrm{C}_{4}\right), 83.68\left(\mathrm{C}_{3}\right), 95.42\left(\mathrm{C}_{2^{\prime}}, \mathrm{C}_{6^{\prime}}\right)$, $110.19\left(\mathrm{C}_{5^{\prime}}{ }^{\prime}\right), 113.35\left(\mathrm{C}_{2^{\prime}}{ }^{\prime}\right), 119.43\left(\mathrm{C}_{6^{\prime}}{ }^{\prime}\right), 120.54\left(\mathrm{C}_{4^{\prime}}\right), 123.99\left(\mathrm{C}_{1^{\prime}}\right), 131.45\left(\mathrm{C}_{1^{\prime}}{ }^{\prime}\right), 145.50\left(\mathrm{C}_{3^{\prime}}{ }^{\prime}\right)$, $147.33\left(\mathrm{C}_{4^{\prime}}\right), 153.16\left(\mathrm{C}_{3^{\prime}}, \mathrm{C}_{5^{\prime}}\right), 157.91\left(\mathrm{C}_{2}\right)$. HRMS: found $428.0653[\mathrm{M}+\mathrm{H}]^{+}$; calculated for $\mathrm{C}_{19} \mathrm{H}_{20} \mathrm{Cl}_{2} \mathrm{NO}_{6}, 428.0668$.

3-Chloro-1-(4-methoxyphenyl)-4-(3,4,5-trimethoxyphenyl)azetidin-2-one (12a)

Compound 12a was synthesised using the general method II above from imine $9 t$ and chloroacetyl chloride to afford the product as an orange powder; yield: $59 \%, \mathrm{Mp}$. 101-102 ${ }^{\circ} \mathrm{C}$ (HPLC: 96\%). IR ( $\mathrm{NaCl}$, film) $\mathrm{V}_{\text {max }}$ : 2604, 2498, 1758 (C=O, $\beta$-lactam), 1598, 1503, 1246, $1126 \mathrm{~cm}^{-1}$. ${ }^{1} \mathrm{H}$ NMR (400 MHz, $\left.\mathrm{CDCl}_{3}\right): \delta 3.78\left(\mathrm{~s}, 3 \mathrm{H}, \mathrm{OCH}_{3}\right), 3.84(\mathrm{~s}, 6 \mathrm{H}$, $\left.\mathrm{OCH}_{3}\right), 3.86\left(\mathrm{~s}, 3 \mathrm{H}, \mathrm{OCH}_{3}\right), 4.63\left(\mathrm{~d}, J=1.48 \mathrm{~Hz}, 1 \mathrm{H}, \mathrm{H}_{4}\right), 4.90\left(\mathrm{~d}, J=2.00 \mathrm{~Hz}, 1 \mathrm{H}, \mathrm{H}_{3}\right)$, $6.56\left(\mathrm{~s}, 2 \mathrm{H}, \mathrm{H}_{2^{\prime}}{ }^{\prime} \mathrm{H}_{6^{\prime}}{ }^{\prime}\right), 6.83\left(\mathrm{~d}, J=9.04 \mathrm{~Hz}, 2 \mathrm{H}, \mathrm{H}_{3^{\prime}} \mathrm{H}_{5^{\prime}}\right), 7.27\left(\mathrm{~d}, J=9.04 \mathrm{~Hz}, 2 \mathrm{H}, \mathrm{H}_{2^{\prime}} \mathrm{H}_{6^{\prime}}\right)$. ${ }^{13} \mathrm{C}$ NMR $\left(100 \mathrm{MHz}, \mathrm{CDCl}_{3}\right): \delta 54.99,55.81,60.44\left(\mathrm{OCH}_{3}\right), 62.80\left(\mathrm{C}_{3}\right), 65.97\left(\mathrm{C}_{4}\right), 102.31$ $\left(\mathrm{C}_{2^{\prime}}{ }^{\prime}, \mathrm{C}_{6^{\prime}}{ }^{\prime}\right), 113.98\left(\mathrm{C}_{3^{\prime}}, \mathrm{C}_{5^{\prime}}\right), 118.46\left(\mathrm{C}_{2^{\prime}}, \mathrm{C}_{6^{\prime}}\right), 129.79\left(\mathrm{C}_{1^{\prime}}\right), 130.12\left(\mathrm{C}_{4^{\prime}}{ }^{\prime}\right), 138.17\left(\mathrm{C}_{1^{\prime}}{ }^{\prime}\right), 153.64$ $\left(\mathrm{C}_{3^{\prime}}{ }^{\prime}, \mathrm{C}_{5^{\prime}}{ }^{\prime}\right), 156.29\left(\mathrm{C}_{4^{\prime}}\right), 159.81\left(\mathrm{C}_{2}\right)$. HRMS: found $400.0928[\mathrm{M}+\mathrm{Na}]^{+} ; \mathrm{C}_{19} \mathrm{H}_{20}{ }^{35} \mathrm{ClNO}_{5} \mathrm{Na}$ requires 400.0928 .

3-Chloro-1-(4-ethoxyphenyl)-4-(3,4,5-trimethoxyphenyl)azetidin-2-one (12b)

Compound $\mathbf{1 2 b}$ was synthesised using the general method II above from imine $\mathbf{9 u}$ and chloroacetyl chloride to afford the product as a creamy powder; yield: $45 \%$, Mp: 113-115 ${ }^{\circ} \mathrm{C}$ (HPLC: 84\%), IR V max: (ATR): 1759.5 (C=O) $\mathrm{cm}^{-1} .{ }^{1} \mathrm{H} \mathrm{NMR}\left(400 \mathrm{MHz} \mathrm{CDCl}_{3}\right)$ : $\delta 1.33-1.38\left(\mathrm{~m}, 3 \mathrm{H}, \mathrm{OCH}_{2} \mathrm{CH}_{3}\right), 3.80\left(\mathrm{~s}, 6 \mathrm{H}, \mathrm{OCH}_{3}\right), 3.83\left(\mathrm{~s}, 3 \mathrm{H}, \mathrm{OCH}_{3}\right), 3.92(\mathrm{~d}, J=3.66 \mathrm{~Hz}$, $\left.2 \mathrm{H}, \mathrm{OCH}_{2} \mathrm{CH}_{3}\right), 4.59\left(\mathrm{~d}, J=1.83 \mathrm{~Hz}, 1 \mathrm{H}, \mathrm{H}_{4}\right), 4.85\left(\mathrm{~d}, J=1.83 \mathrm{~Hz}, 1 \mathrm{H}, \mathrm{H}_{3}\right), 6.52(\mathrm{~s}, 2 \mathrm{H}, \mathrm{ArH})$, $6.78(\mathrm{~d}, J=9.16 \mathrm{~Hz}, 2 \mathrm{H}, \mathrm{ArH}), 7.22(\mathrm{~d}, J=8.54 \mathrm{~Hz}, 2 \mathrm{H}, \mathrm{ArH}) .{ }^{13} \mathrm{C}$ NMR $\left(100 \mathrm{MHz}, \mathrm{CDCl}_{3}\right)$ : 
$\delta 14.73,56.24,60.85,63.24,66.39,102.81,106.70,114.97,118.88,121.97,130.57,154.07,156.13$, $160.17\left(\mathrm{C}_{2}, \mathrm{C}=\mathrm{O}\right)$. HRMS: found $414.1080[\mathrm{M}+\mathrm{Na}]^{+} ; \mathrm{C}_{20} \mathrm{H}_{22}{ }^{35} \mathrm{ClNNaO}_{5}$ requires 414.1084 .

3-Chloro-1-(4-(methylthio)phenyl)-4-(3,4,5-trimethoxyphenyl) azetidin-2-one (12c)

Compound 12c was synthesised using the general method II above from imine $19 \mathrm{v}$ and chloroacetyl chloride to afford the product as orange powder; yield: $50 \%, \mathrm{Mp}: 101-103{ }^{\circ} \mathrm{C}$. IR V $V_{\text {max }}$ : (ATR): $1760.6(\mathrm{C}=\mathrm{O}) \mathrm{cm}^{-1}$. ${ }^{1} \mathrm{H} \mathrm{NMR}\left(400 \mathrm{MHz}, \mathrm{CDCl}_{3}\right): \delta 2.42\left(\mathrm{~s}, 3 \mathrm{H}, \mathrm{SCH}_{3}\right), 3.80$ $\left(\mathrm{s}, 6 \mathrm{H}, \mathrm{OCH}_{3}\right), 3.83\left(\mathrm{~s}, 3 \mathrm{H}, \mathrm{OCH}_{3}\right), 4.60(\mathrm{~d}, J=1.83 \mathrm{~Hz}, 1 \mathrm{H}, \mathrm{H} 4), 4.87(\mathrm{~d}, J=2.44 \mathrm{~Hz}, 1 \mathrm{H}$, $\mathrm{H} 3), 6.52$ (s, 2H, ArH), 7.13-7.17 (m, 2H, ArH), 7.20-7.24 (m, 2H, ArH). ${ }^{13} \mathrm{C}$ NMR (100 MHz, $\left.\mathrm{CDCl}_{3}\right): \delta 16.17,56.27,60.85,63.22,66.39,102.77,106.71,118.03,120.68,127.59,130.31$, $134.89,154.13,160.53\left(\mathrm{C}_{2}, \mathrm{C}=\mathrm{O}\right)$. HRMS: found $416.0701[\mathrm{M}+\mathrm{Na}]^{+} ; \mathrm{C}_{19} \mathrm{H}_{20}{ }^{35} \mathrm{ClNNaO}_{4} \mathrm{~S}$ requires 416.0699 .

3,3-Dichloro-4-(3,4,5-trimethoxyphenyl)-1-(4-methoxyphenyl)azetidin-2-one (13a)

Compound 13a was prepared as described in the general method II above from imine 9t and dichloroacetyl chloride; yield: $18 \%, 379 \mathrm{mg}$, yellow solid, Mp. $64-66{ }^{\circ} \mathrm{C}$ (HPLC: 100\%). IR (KBr) $V_{\text {max }}$ : 2605, 2498, 1778 (C=O, $\beta$-lactam), 1691, 1592, 1508, 1250, 1127 $\mathrm{cm}^{-1} .{ }^{1} \mathrm{H}$ NMR $\left(400 \mathrm{MHz} \mathrm{CDCl}_{3}\right): \delta 3.79\left(\mathrm{~s}, 3 \mathrm{H}, \mathrm{OCH}_{3}\right), 3.83\left(\mathrm{~s}, 6 \mathrm{H}, \mathrm{OCH}_{3}\right), 3.89(\mathrm{~s}, 3 \mathrm{H}$, $\left.\mathrm{OCH}_{3}\right), 5.39\left(\mathrm{~s}, 1 \mathrm{H}, \mathrm{H}_{4}\right), 6.51\left(\mathrm{~s}, 2 \mathrm{H}, \mathrm{H}_{2^{\prime}}{ }^{\prime} \mathrm{H}_{6^{\prime}}{ }^{\prime}\right), 6.86\left(\mathrm{~d}, J=8.00 \mathrm{~Hz}, 2 \mathrm{H}, \mathrm{H}_{3^{\prime}} \mathrm{H}_{5^{\prime}}\right), 7.29$ $\left(\mathrm{d}, J=8.04 \mathrm{~Hz}, 2 \mathrm{H}, \mathrm{H}_{2^{\prime}} \mathrm{H}_{6^{\prime}}\right) .{ }^{13} \mathrm{C} \mathrm{NMR}\left(100 \mathrm{MHz}, \mathrm{CDCl}_{3}\right): \delta 55.02,55.81,60.48\left(\mathrm{OCH}_{3}\right)$, $73.86\left(\mathrm{C}_{4}\right), 83.70\left(\mathrm{C}_{3}\right), 104.26\left(\mathrm{C}_{2^{\prime}}{ }^{\prime}, \mathrm{C}_{6^{\prime}}{ }^{\prime}\right), 114.10\left(\mathrm{C}_{3^{\prime}}, \mathrm{C}_{5^{\prime}}\right), 118.98\left(\mathrm{C}_{2^{\prime}}, \mathrm{C}_{6^{\prime}}\right), 126.59\left(\mathrm{C}_{1^{\prime}}\right)$, $128.69\left(\mathrm{C}_{4^{\prime}}{ }^{\prime}\right), 138.56\left(\mathrm{C}_{1^{\prime}}{ }^{\prime}\right), 153.18\left(\mathrm{C}_{3^{\prime}}{ }^{\prime}, \mathrm{C}_{5^{\prime}}{ }^{\prime}\right), 156.77\left(\mathrm{C}_{4^{\prime}}\right), 157.51\left(\mathrm{C}_{2}\right)$. HRMS: found $434.0535[\mathrm{M}+\mathrm{Na}]^{+} ; \mathrm{C}_{19} \mathrm{H}_{19}{ }^{35} \mathrm{Cl}_{2} \mathrm{NO}_{5} \mathrm{Na}$ requires 434.0538 .

3,3-Dichloro-1-(4-ethoxyphenyl)-4-(3,4,5-trimethoxyphenyl)azetidin-2-one (13b)

Compound $\mathbf{1 3 b}$ was synthesised using the general method II above from imine $\mathbf{9 u}$ and dichloroacetyl chloride to afford the product as a brown powder; yield: $25 \%, \mathrm{Mp}$ : 133-134 ${ }^{\circ} \mathrm{C}$. IR V $\max$ : (ATR): $1774.5(\mathrm{C}=\mathrm{O}) \mathrm{cm}^{-1}$. ${ }^{1} \mathrm{H}$ NMR $\left(400 \mathrm{MHz}, \mathrm{CDCl}_{3}\right): \delta 1.37$ $\left(\mathrm{t}, J=7.02 \mathrm{~Hz}, 3 \mathrm{H}, \mathrm{OCH}_{2} \mathrm{CH}_{3}\right), 3.79\left(\mathrm{~s}, 6 \mathrm{H}, \mathrm{OCH}_{3}\right), 3.86\left(\mathrm{~s}, 3 \mathrm{H}, \mathrm{OCH}_{3}\right), 3.97(\mathrm{q}, J=6.71 \mathrm{~Hz}$, $\left.2 \mathrm{H}, \mathrm{OCH}_{2} \mathrm{CH}_{3}\right), 5.34$ (s, $\left.1 \mathrm{H}, \mathrm{H} 4\right), 6.47$ (s, $\left.2 \mathrm{H}, \mathrm{ArH}\right), 6.77-6.84$ (m, $\left.2 \mathrm{H}, \mathrm{ArH}\right), 7.23-7.25$ (m, $2 \mathrm{H}, \mathrm{ArH}) .{ }^{13} \mathrm{C} \mathrm{NMR}\left(100 \mathrm{MHz}, \mathrm{CDCl}_{3}\right): \delta 14.29,55.44,56.25,60.88,74.31,81.62,104.77$, $114.54,119.39,127.00,129.15,153.61,157.22,159.65\left(C_{2}, C=O\right)$. HRMS: found 448.0676 $[\mathrm{M}+\mathrm{Na}]^{+} ; \mathrm{C}_{20} \mathrm{H}_{21}{ }^{35} \mathrm{Cl}_{2} \mathrm{NNaO}_{5}$ requires 448.0694 .

3,3-Dichloro-1-(4-(methylthio)phenyl)-4-(3,4,5-trimethoxyphenyl) azetidin-2-one (13c)

Compound 13c was synthesised using the general method II above from imine $\mathbf{9 v}$ and dichloroacetyl chloride to afford the product as brown solid; yield: $47 \%$, Mp: $117-119{ }^{\circ} \mathrm{C}$ (HPLC: 98\%), IR V max: (ATR): $1771.9(\mathrm{C}=\mathrm{O}) \mathrm{cm}^{-1} .{ }^{1} \mathrm{H}$ NMR $\left(400 \mathrm{MHz}, \mathrm{CDCl}_{3}\right): \delta 2.43$ $\left(\mathrm{s}, 3 \mathrm{H}, \mathrm{SCH}_{3}\right), 3.79\left(\mathrm{~s}, 6 \mathrm{H}, \mathrm{OCH}_{3}\right), 3.86\left(\mathrm{~s}, 3 \mathrm{H}, \mathrm{OCH}_{3}\right), 5.36(\mathrm{~s}, 1 \mathrm{H}, \mathrm{H} 4), 6.47$ (s, 2H, ArH), 7.18 (s, 2H, ArH), 7.23 (s, 2H, ArH). $\left.{ }^{13} \mathrm{C} \mathrm{NMR} \mathrm{(100} \mathrm{MHz,} \mathrm{CDCl}_{3}\right): \delta 15.98,56.28,60.89,74.28$, 83.63, 104.73, 118.51, 126.77, 127.41, 133.11, 135.91, 139.17, 153.67, 158.19 ( $\left.\mathrm{C}_{2}, \mathrm{C}=\mathrm{O}\right)$. HRMS: found $450.0320[\mathrm{M}+\mathrm{Na}]^{+} ; \mathrm{C}_{19} \mathrm{H}_{19}{ }^{35} \mathrm{Cl}_{2} \mathrm{NNaO}_{4} \mathrm{~S}$ requires 450.0310 .

3-Chloro-1-(3,5-dimethoxyphenyl)-4-(4-methoxyphenyl)azetidin-2-one (14a)

Compound 14a was synthesised using the general method II above from imine $\mathbf{9 w}$ and chloroacetyl chloride to afford the product as yellow powder; yield: 8\%, Mp: 93-94 ${ }^{\circ} \mathrm{C}$, IR V $V_{\text {max }}$ (ATR): $1751.3(\mathrm{C}=\mathrm{O}) \mathrm{cm}^{-1} .{ }^{1} \mathrm{H} \mathrm{NMR}\left(400 \mathrm{MHz} \mathrm{CDCl}_{3}\right): \delta 3.65\left(\mathrm{~s}, 6 \mathrm{H}, \mathrm{OCH}_{3}\right), 3.71$ $\left(\mathrm{s}, 3 \mathrm{H}, \mathrm{OCH}_{3}\right), 4.45(\mathrm{~s}, 1 \mathrm{H}, \mathrm{H} 4), 4.68(\mathrm{~s}, 1 \mathrm{H}, \mathrm{H} 3), 6.11-6.20(\mathrm{~m}, 1 \mathrm{H}, \mathrm{ArH}), 6.43(\mathrm{~d}, \mathrm{~J}=1.83 \mathrm{~Hz}$, $2 \mathrm{H}, \mathrm{ArH}), 6.80(\mathrm{~d}, J=8.54 \mathrm{~Hz}, 2 \mathrm{H}, \mathrm{ArH}), 7.28$ (s, 2H, ArH). ${ }^{13} \mathrm{C} \mathrm{NMR}\left(100 \mathrm{MHz}, \mathrm{CDCl}_{3}\right)$ : $\delta 56.45,60.67,63.45,66.36,95.22,115.56,126.95,127.88,132.13,135.10,153.52,158.77,160.55$ $\left(\mathrm{C}_{2}, \mathrm{C}=\mathrm{O}\right)$. HRMS: calculated for $\mathrm{C}_{18} \mathrm{H}_{19}{ }^{35} \mathrm{ClNO}_{4}[\mathrm{M}+\mathrm{H}]^{+} 348.1003$; found 348.1000. 
3-Chloro-1-(3,5-dimethoxyphenyl)-4-(4-ethoxyphenyl)azetidin-2-one (14b)

Compound $\mathbf{1 4 b}$ was synthesised using the general method II above from imine $\mathbf{9 x}$ and chloroacetyl chloride to afford the product as an oil; yield: $20 \%$, Mp: $129-130{ }^{\circ} \mathrm{C}$, IR $\mathrm{V}_{\max }(\mathrm{ATR}): 1753.6(\mathrm{C}=\mathrm{O}) \mathrm{cm}^{-1} .{ }^{1} \mathrm{H}$ NMR $\left(400 \mathrm{MHz}, \mathrm{CDCl}_{3}\right): \delta 1.39(\mathrm{t}, J=6.71 \mathrm{~Hz}, 3 \mathrm{H}$, $\left.\mathrm{OCH}_{2} \mathrm{CH}_{3}\right), 3.68\left(\mathrm{~s}, 6 \mathrm{H}, \mathrm{OCH}_{3}\right), 4.01\left(\mathrm{q}, J=7.12 \mathrm{~Hz}, 2 \mathrm{H}, \mathrm{OCH}_{2} \mathrm{CH}_{3}\right), 4.55(\mathrm{~s}, 1 \mathrm{H}, \mathrm{H} 4), 4.88$ (s, 1H, H3), 6.13-6.23 (m, 1H, ArH), $6.45(\mathrm{~d}, J=1.83 \mathrm{~Hz}, 2 \mathrm{H}, \mathrm{ArH}), 6.89(\mathrm{~d}, J=8.54 \mathrm{~Hz}$, $2 \mathrm{H}, \mathrm{ArH}), 7.27$ (s, 2H, ArH). ${ }^{13} \mathrm{C}$ NMR $\left(100 \mathrm{MHz}, \mathrm{CDCl}_{3}\right): \delta 14.33,56.45,60.67,63.45$, $66.36,95.22,115.56,126.95,127.88,132.13,135.10,153.52,158.77,160.55\left(C_{2}, C=O\right)$. HRMS: calculated for $\mathrm{C}_{19} \mathrm{H}_{20}{ }^{35} \mathrm{ClNNaO}_{4}[\mathrm{M}+\mathrm{Na}]^{+}$384.0979; found 384.0992.

3,3-Dichloro-1-(3,5-dimethoxyphenyl)-4-(4-methoxyphenyl)azetidin-2-one (15a)

Compound 15a was synthesised using method II above from imine $9 \mathrm{w}$ and dichloroacetyl chloride to afford the product as yellow oil; yield: 13\% (HPLC: 95\%), IR $\mathrm{V}_{\max }$ (ATR): 1774.6 $(\mathrm{C}=\mathrm{O}) \mathrm{cm}^{-1} .{ }^{1} \mathrm{H}$ NMR $\left(400 \mathrm{MHz}, \mathrm{CDCl}_{3}\right): \delta 3.71\left(\mathrm{~s}, 6 \mathrm{H}, \mathrm{OCH}_{3}\right), 3.82\left(\mathrm{~s}, 3 \mathrm{H}, \mathrm{OCH}_{3}\right), 5.40$ $(\mathrm{s}, 1 \mathrm{H}, \mathrm{H} 4), 6.24(\mathrm{t}, J=2.14 \mathrm{~Hz}, 1 \mathrm{H}, \mathrm{ArH}), 6.48(\mathrm{~d}, J=2.44 \mathrm{~Hz}, 2 \mathrm{H}, \mathrm{ArH}), 6.93(\mathrm{~d}, J=9.16 \mathrm{~Hz}$, $2 \mathrm{H}, \mathrm{ArH}), 7.23(\mathrm{~d}, J=8.54 \mathrm{~Hz}, 2 \mathrm{H}, \mathrm{ArH}) .{ }^{13} \mathrm{C}$ NMR $\left(100 \mathrm{MHz}, \mathrm{CDCl}_{3}\right): \delta 55.30,55.43,74.03$, 83.43, 96.75, 97.64, 114.32, 123.41, 129.11, 137.46, 158.67, $160.75\left(\mathrm{C}_{2}, \mathrm{C}=\mathrm{O}\right)$. HRMS: calculated for $\mathrm{C}_{18} \mathrm{H}_{17}{ }^{35} \mathrm{Cl}_{2} \mathrm{NNaO}_{4}[\mathrm{M}+\mathrm{Na}]^{+}$404.0432; found 404.0428.

3,3-Dichloro-1-(3,5-dimethoxyphenyl)-4-(4-ethoxyphenyl)azetidin-2-one (15b)

Compound $15 b$ was synthesised using method II above from imine $9 x$ and dichloroacetyl chloride to afford the product as a brown oil; yield: 7\% (HPLC: 96\%), IR $\mathrm{V}_{\max }$ (ATR): 1772.4 $(\mathrm{C}=\mathrm{O}) \mathrm{cm}^{-1} .{ }^{1} \mathrm{H}$ NMR $\left(400 \mathrm{MHz}, \mathrm{CDCl}_{3}\right): \delta 1.40\left(\mathrm{t}, J=6.71 \mathrm{~Hz}, 3 \mathrm{H}, \mathrm{OCH}_{2} \mathrm{CH}_{3}\right), 3.69(\mathrm{~s}, 6 \mathrm{H}$, $\left.\mathrm{OCH}_{3}\right), 4.02\left(\mathrm{q}, J=7.32 \mathrm{~Hz}, 2 \mathrm{H}, \mathrm{OCH}_{2} \mathrm{CH}_{3}\right), 5.38(\mathrm{~s}, 1 \mathrm{H}, \mathrm{H} 4), 6.20-6.25(\mathrm{~m}, 1 \mathrm{H}, \mathrm{ArH}), 6.47$ (s, 2H, ArH), $6.90(\mathrm{~m}, J=8.55 \mathrm{~Hz}, 2 \mathrm{H}, \mathrm{ArH}), 7.21(\mathrm{~m}, J=8.54 \mathrm{~Hz}, 2 \mathrm{H}, \mathrm{ArH}) .{ }^{13} \mathrm{C}$ NMR $\left(100 \mathrm{MHz}, \mathrm{CDCl}_{3}\right): \delta 14.74,55.41,63.52,74.06,84.24,96.74,97.63,114.75,123.18,129.08$, 137.47, 158.67, $160.15\left(\mathrm{C}_{2}, \mathrm{C}=\mathrm{O}\right)$. HRMS: calculated for $\mathrm{C}_{19} \mathrm{H}_{19}{ }^{35} \mathrm{Cl}_{2} \mathrm{NNaO}_{4}[\mathrm{M}+\mathrm{Na}]^{+}$ 418.0589; found 418.0574.

3-Bromo-4-(4-methoxyphenyl)-1-(3,4,5-trimethoxyphenyl)azetidin-2-one (16a)

Compound 16a was synthesised from imine $\mathbf{9 e}$ and bromoacetyl chloride using the general method II above and afford a product as a red oil; yield: 11\% (HPLC: 100\%). IR $\mathrm{V}_{\text {max }}$ : (ATR): $1757.1(\mathrm{C}=\mathrm{O}) \mathrm{cm}^{-1} .{ }^{1} \mathrm{H}$ NMR $\left(400 \mathrm{MHz}, \mathrm{CDCl}_{3}\right): \delta 3.66\left(\mathrm{~s}, 6 \mathrm{H}, \mathrm{OCH}_{3}\right), 3.71$ $\left(\mathrm{s}, 3 \mathrm{H}, \mathrm{OCH}_{3}\right), 3.77\left(\mathrm{~s}, 3 \mathrm{H}, \mathrm{OCH}_{3}\right), 4.65(\mathrm{~d}, J=1.96 \mathrm{~Hz}, 1 \mathrm{H}, \mathrm{H} 4), 5.05(\mathrm{~d}, J=1.96 \mathrm{~Hz}, 1 \mathrm{H}$, H3), $6.48(\mathrm{~s}, 2 \mathrm{H}, \mathrm{ArH}), 6.89(\mathrm{~m}, J=8.71 \mathrm{~Hz}, 2 \mathrm{H}, \mathrm{ArH}), 7.27(\mathrm{~m}, J=8.71 \mathrm{~Hz}, 2 \mathrm{H}, \mathrm{ArH})$. ${ }^{13} \mathrm{C}$ NMR $\left(100 \mathrm{MHz}, \mathrm{CDCl}_{3}\right): \delta 49.91,55.33,56.00,60.51,66.14,95.34,114.79,127.54$, 131.44, 132.85, 135.07, 153.46, 160.47, $170.54\left(\mathrm{C}_{2}, \mathrm{C}=\mathrm{O}\right)$. HRMS: found 444.0452 [M + Na] $]^{+}$; $\mathrm{C}_{19} \mathrm{H}_{20}{ }^{79} \mathrm{BrNaNO}_{5}$ requires 444.0423 .

3-Bromo-4-(4-ethoxyphenyl)-1-(3,4,5-trimethoxyphenyl)azetidin-2-one (16b)

Compound $16 \mathrm{~b}$ was prepared from imine $9 \mathrm{f}$ and bromoacetyl chloride using the general method II above and afforded the product as an oil; yield: $31 \%$ (HPLC: 95\%). IR $\mathrm{V}_{\max }(\mathrm{ATR}): 1735.6(\mathrm{C}=\mathrm{O}) \mathrm{cm}^{-1} .{ }^{1} \mathrm{H}$ NMR $\left(400 \mathrm{MHz}, \mathrm{CDCl}_{3}\right): \delta 1.31(\mathrm{t}, J=6.84 \mathrm{~Hz}, 3 \mathrm{H}$, $\left.\mathrm{OCH}_{2} \mathrm{CH}_{3}\right), 3.70\left(\mathrm{~s}, 3 \mathrm{H}, \mathrm{OCH}_{3}\right), 3.79\left(\mathrm{~s}, 6 \mathrm{H}, \mathrm{OCH}_{3}\right), 4.02\left(\mathrm{q}, 2 \mathrm{H}, J=6.61 \mathrm{~Hz}, \mathrm{OCH}_{2} \mathrm{CH}_{3}\right)$, $4.86\left(\mathrm{~d}, J=1.66 \mathrm{~Hz}, 1 \mathrm{H}, \mathrm{H}_{4}\right), 4.95\left(\mathrm{~d}, J=1.66 \mathrm{~Hz}, 1 \mathrm{H}, \mathrm{H}_{3}\right), 6.44(\mathrm{~s}, 2 \mathrm{H}, \mathrm{ArH}), 6.84(\mathrm{~d}$, $J=8.71 \mathrm{~Hz}, 2 \mathrm{H}, \mathrm{ArH}), 7.23(\mathrm{~d}, J=8.71 \mathrm{~Hz}, 2 \mathrm{H}, \mathrm{ArH}) .{ }^{13} \mathrm{C} \mathrm{NMR}\left(100 \mathrm{MHz}, \mathrm{CDCl}_{3}\right): \delta 14.30$, $49.78,55.91,60.59,63.54,66.17,95.36,115.24,126.35,127.55,132.79,135.39,159.82,161.10$, $170.46\left(\mathrm{C}_{2}, \mathrm{C}=\mathrm{O}\right)$. HRMS: found $\left.458.0550 \mathrm{M}+\mathrm{H}\right]^{+} ; \mathrm{C}_{20} \mathrm{H}_{22}{ }^{79} \mathrm{BrNaNO}_{5}$ requires 458.0579.

3-Bromo-4-(4-(methylthio)phenyl)-1-(3,4,5-trimethoxyphenyl)azetidin-2-one (16c)

Compound $16 \mathrm{c}$ was prepared from imine $9 \mathrm{i}$ and bromoacetyl chloride following the general method II above to afford the product as an oil; yield: $30 \%$ (HPLC: $100 \%$ ). IR $\mathrm{V}_{\max }$ (ATR): $1757.9(\mathrm{C}=\mathrm{O}) \mathrm{cm}^{-1} .{ }^{1} \mathrm{H}$ NMR $\left(400 \mathrm{MHz}, \mathrm{CDCl}_{3}\right): \delta 2.42\left(\mathrm{~s}, 3 \mathrm{H}, \mathrm{SCH}_{3}\right), 3.65(\mathrm{~s}, 3 \mathrm{H}$, $\left.\mathrm{OCH}_{3}\right), 3.85\left(\mathrm{~s}, 6 \mathrm{H}, \mathrm{OCH}_{3}\right), 4.56\left(\mathrm{~d}, J=1.66 \mathrm{~Hz}, 1 \mathrm{H}, \mathrm{H}_{4}\right), 4.90\left(\mathrm{~d}, J=1.66 \mathrm{~Hz}, 1 \mathrm{H}, \mathrm{H}_{3}\right), 6.46(\mathrm{~s}$, 
$2 \mathrm{H}, \mathrm{ArH}), 7.19-7.23$ (m, $2 \mathrm{H}, \mathrm{ArH}), 7.24$ (s, 2H, ArH). $\left.{ }^{13} \mathrm{C} \mathrm{NMR} \mathrm{(100} \mathrm{MHz,} \mathrm{CDCl}_{3}\right): \delta 15.28$, $49.70,56.05,60.88,66.90,95.36,126.61,127.34,131.14,132.70,135.13,140.76,153.49,170.39$ $\left(\mathrm{C}_{2}, \mathrm{C}=\mathrm{O}\right)$. HRMS: found $460.0165[\mathrm{M}+\mathrm{Na}]^{+} ; \mathrm{C}_{19} \mathrm{H}_{20}{ }^{79} \mathrm{BrNaNO}_{4} \mathrm{~S}$ requires 460.0194 .

3-Bromo-4-(4-(ethylthio)phenyl)-1-(3,4,5-trimethoxyphenyl)azetidin-2-one (16d)

Compound 16d was prepared following the general method II above from imine 90 and bromoacetyl chloride to afford the title product as a brown oil; yield: 22\% (HPLC: $97 \%$ ). IR V $V_{\max }$ (ATR): $1760.1(\mathrm{C}=\mathrm{O}) \mathrm{cm}^{-1} .{ }^{1} \mathrm{H}$ NMR $\left(400 \mathrm{MHz}, \mathrm{CDCl}_{3}\right): \delta 1.10(\mathrm{t}, J=7.46 \mathrm{~Hz}, 3 \mathrm{H}$, $\left.\mathrm{SCH}_{2} \mathrm{CH}_{3}\right), 2.78\left(\mathrm{q}, J=7.46 \mathrm{~Hz}, 2 \mathrm{H}, \mathrm{SCH}_{2} \mathrm{CH}_{3}\right), 3.61\left(\mathrm{~s}, 3 \mathrm{H}, \mathrm{OCH}_{3}\right), 3.68\left(\mathrm{~s}, 6 \mathrm{H}, \mathrm{OCH}_{3}\right), 4.03$ $\left(\mathrm{d}, J=1.66 \mathrm{~Hz}, 1 \mathrm{H}, \mathrm{H}_{4}\right), 4.89\left(\mathrm{~d}, J=1.66 \mathrm{~Hz}, 1 \mathrm{H}, \mathrm{H}_{3}\right), 6.43(\mathrm{~s}, 2 \mathrm{H}, \mathrm{ArH}), 7.17(\mathrm{~s}, 2 \mathrm{H}, \mathrm{ArH})$, 7.76 (s, 2H, ArH). ${ }^{13} \mathrm{C}$ NMR (100 MHz, $\left.\mathrm{CDCl}_{3}\right): \delta 15.26,26.86,49.53,55.98,60.83,62.74$, 66.06, 95.39, 126.67, 128.74, 131.67, 132.64, 135.06, 139.16, 153.43, $171.04\left(\mathrm{C}_{2}, \mathrm{C}=\mathrm{O}\right)$. HRMS: found $474.0378[\mathrm{M}+\mathrm{Na}]^{+} ; \mathrm{C}_{20} \mathrm{H}_{22}{ }^{79} \mathrm{BrNaNO}_{4} \mathrm{~S}$ requires 474.0351 .

3-Bromo-4-(4-methoxy-3-methylphenyl)-1-(3,4,5-trimethoxyphenyl) azetidin-2-one (16e)

Compound 16e was prepared using the general procedure II above from imine $\mathbf{9 p}$, and bromoacetyl chloride to afford the product as an oil; yield: $29 \%$ (HPLC: $95 \%$ ). IR $\mathrm{V}_{\max }(\mathrm{ATR}): 1758.6(\mathrm{C}=\mathrm{O}) \mathrm{cm}^{-1} .{ }^{1} \mathrm{H}$ NMR $\left(400 \mathrm{MHz}, \mathrm{CDCl}_{3}\right): \delta 2.12\left(\mathrm{~s}, 3 \mathrm{H}, \mathrm{CH}_{3}\right), 3.62$ $\left(\mathrm{s}, 3 \mathrm{H}, \mathrm{OCH}_{3}\right) 3.67\left(\mathrm{~s}, 6 \mathrm{H}, \mathrm{OCH}_{3}\right), 3.73\left(\mathrm{~s}, 3 \mathrm{H}, \mathrm{OCH}_{3}\right), 4.53(\mathrm{~d}, J=1.66 \mathrm{~Hz}, 1 \mathrm{H}, \mathrm{H} 4), 4.83$ $(\mathrm{d}, J=1.66 \mathrm{~Hz}, 1 \mathrm{H}, \mathrm{H} 3), 6.47$ (s, 2H, ArH), $6.76(\mathrm{~s}, 1 \mathrm{H}, \mathrm{ArH}), 7.08(\mathrm{~s}, 1 \mathrm{H}, \mathrm{ArH}), 7.12(\mathrm{~s}$, $1 \mathrm{H}, \mathrm{ArH}) .{ }^{13} \mathrm{C}$ NMR $\left(100 \mathrm{MHz}, \mathrm{CDCl}_{3}\right): \delta 15.42,49.23,56.31,61.73,68.49,99.02,115.72$, $123.12,125.50,130.65,134.41,135.27,136.86,153.03,156.78,170.49\left(C_{2}, C=O\right)$. HRMS: found $436.0764[\mathrm{M}+\mathrm{H}]^{+} ; \mathrm{C}_{20} \mathrm{H}_{23}{ }^{79} \mathrm{BrNO}_{5}$ requires 436.0760.

3-Bromo-4-(3-fluoro-4-methoxyphenyl)-1-(3,4,5-trimethoxyphenyl) azetidin-2-one (16f)

Compound 16f was prepared using the general procedure II above from imine $\mathbf{9 q}$, and bromoacetyl chloride to afford the product as an oil; yield: $25 \%$; (HPLC: $96 \%$ ). IR $V_{\max }$ (ATR): $1760.2(\mathrm{C}=\mathrm{O}) \mathrm{cm}^{-1} .{ }^{1} \mathrm{H}$ NMR $\left(400 \mathrm{MHz}, \mathrm{CDCl}_{3}\right): \delta 3.77\left(\mathrm{~s}, 3 \mathrm{H}, \mathrm{OCH}_{3}\right), 3.81(\mathrm{~s}, 9 \mathrm{H}$, $\left.\mathrm{OCH}_{3}\right), 4.56(\mathrm{~d}, J=1.66 \mathrm{~Hz}, 1 \mathrm{H}, \mathrm{H} 4), 4.87(\mathrm{~d}, J=1.66 \mathrm{~Hz}, 1 \mathrm{H}, \mathrm{H} 3), 6.47(\mathrm{~s}, 2 \mathrm{H}, \mathrm{ArH}), 7.14$ (m, 3H, ArH). ${ }^{13} \mathrm{C}$ NMR $\left(100 \mathrm{MHz}, \mathrm{CDCl}_{3}\right): \delta 49.73,55.56,56.71,60.88,65.49,95.29,113.31$, $114.15,122.33,127.52,132.64,135.25,148.56,151.46,153.57,171.32\left(C_{2}, C=O\right)$. HRMS: found $462.0340[\mathrm{M}+\mathrm{H}]^{+} ; \mathrm{C}_{19} \mathrm{H}_{19}{ }^{79} \mathrm{BrFNaNO}_{5}$ requires 462.0328 .

3-Bromo-4-(3-chloro-4-methoxyphenyl)-1-(3,4,5-trimethoxyphenyl) azetidin-2-one (16g)

Compound $16 \mathrm{~g}$ was prepared using the general procedure II above from $9 \mathrm{r}$ and bromoacetyl chloride to afford the product as yellow oil; yield: 29\% (HPLC: 100\%). IR $\mathrm{V}_{\max }(\mathrm{ATR}): 1759.6(\mathrm{C}=\mathrm{O}) \mathrm{cm}^{-1} .{ }^{1} \mathrm{H}$ NMR $\left(400 \mathrm{MHz}, \mathrm{CDCl}_{3}\right): \delta 3.71\left(\mathrm{~s}, 3 \mathrm{H}, \mathrm{OCH}_{3}\right), 3.66$ $\left(\mathrm{s}, 6 \mathrm{H}, \mathrm{OCH}_{3}\right), 3.84\left(\mathrm{~s}, 3 \mathrm{H}, \mathrm{OCH}_{3}\right), 4.57\left(\mathrm{~d}, J=2.07 \mathrm{~Hz}, 1 \mathrm{H}, \mathrm{H}_{4}\right), 4.86(\mathrm{~d}, J=2.07 \mathrm{~Hz}, 1 \mathrm{H}$, $\left.\mathrm{H}_{3}\right), 6.46(\mathrm{~s}, 2 \mathrm{H}, \mathrm{ArH}), 6.92(\mathrm{~s}, 1 \mathrm{H}, \mathrm{ArH}), 7.22(\mathrm{~s}, 1 \mathrm{H}, \mathrm{ArH}), 7.36(\mathrm{~s}, 1 \mathrm{H}, \mathrm{ArH}) .{ }^{13} \mathrm{C}$ NMR $\left(100 \mathrm{MHz}, \mathrm{CDCl}_{3}\right): \delta 49.73,56.06,56.23,60.87,65.34,95.30,112.61,123.55,125.68,128.02$, 132.63, 135.23, 136.55, 152.86, 156.27, $160.47\left(\mathrm{C}_{2}, \mathrm{C}=\mathrm{O}\right)$. HRMS: found 478.0016 [M + Na] ${ }^{+}$; $\mathrm{C}_{19} \mathrm{H}_{19}{ }^{79} \mathrm{Br}^{35} \mathrm{ClNaNO}_{5}$ requires 478.0033 .

3-Bromo-4-(3-bromo-4-methoxyphenyl)-1-(3,4,5-trimethoxyphenyl) azetidin-2-one (16h)

Compound 16h was prepared using the general procedure II above from imine $9 \mathrm{~s}$, and bromoacetyl chloride to afford the product as brown oil; yield: $20 \%$ (HPLC: $100 \%$ ). IR $\mathrm{V}_{\max }(\mathrm{ATR}): 1758.9(\mathrm{C}=\mathrm{O}) \mathrm{cm}^{-1} .{ }^{1} \mathrm{H}$ NMR $\left(400 \mathrm{MHz}, \mathrm{CDCl}_{3}\right): \delta 3.78\left(\mathrm{~s}, 3 \mathrm{H}, \mathrm{OCH}_{3}\right), 3.84$ $\left(\mathrm{s}, 6 \mathrm{H}, \mathrm{OCH}_{3}\right), 4.05\left(\mathrm{~s}, 3 \mathrm{H}, \mathrm{OCH}_{3}\right), 4.57\left(\mathrm{~d}, J=1.66 \mathrm{~Hz}, 1 \mathrm{H}, \mathrm{H}_{4}\right), 4.86(\mathrm{~d}, J=1.66 \mathrm{~Hz}, 1 \mathrm{H}$, $\left.\mathrm{H}_{3}\right), 6.46(\mathrm{~s}, 2 \mathrm{H}, \mathrm{ArH}), 6.88(\mathrm{~s}, 1 \mathrm{H}, \mathrm{ArH}), 6.84(\mathrm{~s}, 1 \mathrm{H}, \mathrm{ArH}), 7.54(\mathrm{~s}, 1 \mathrm{H}, \mathrm{ArH}) .{ }^{13} \mathrm{C}$ NMR $\left(100 \mathrm{MHz}, \mathrm{CDCl}_{3}\right): \delta 55.13,56.23,60.54,66.43,100.18,112.36,114.51,126.04,132.21$, $134.78,136.55,137.60,154.63,156.32,170.70\left(\mathrm{C}_{2}, \mathrm{C}=\mathrm{O}\right)$. HRMS: found $521.9500[\mathrm{M}+\mathrm{Na}]^{+}$; $\mathrm{C}_{19} \mathrm{H}_{19}{ }^{79} \mathrm{Br}_{2} \mathrm{NaNO}_{5}$ requires 521.9528 . 
3-Bromo-4-(3-(tert-butyldimethylsilyl)-4-methoxyphenyl)-1-(3,4,5-trimethoxyphenyl) azetidin-2-one (16i)

Compound 16i was prepared using the general procedure II above from protected TBDMS imine $9 \mathrm{~m}$ ( $2 \mathrm{mmol})$ and bromoacetyl chloride $(6 \mathrm{mmol})$. The product was isolated as a red oil; $50 \mathrm{mg}$, yield: 5\%, HPLC: $98 \%$. IR $\mathrm{V}_{\max }$ (ATR): $1760.02 \mathrm{~cm}^{-1}$ (C=O, $\beta$-lactam). ${ }^{1} \mathrm{H}$ NMR $\left(400 \mathrm{MHz}, \mathrm{CDCl}_{3}\right) \delta$ ppm $0.04\left(\mathrm{~s}, 6 \mathrm{H}, \mathrm{Si}-\mathrm{CH}_{3}\right), 0.88\left(\mathrm{~s}, 9 \mathrm{H}, \mathrm{CH}_{3}\right), 3.65(\mathrm{~s}, 3 \mathrm{H}$, $\left.\mathrm{OCH}_{3}\right), 3.71\left(\mathrm{~s}, 6 \mathrm{H}, \mathrm{OCH}_{3}\right), 4.57\left(\mathrm{~d}, \mathrm{~J}=2.07 \mathrm{~Hz}, 1 \mathrm{H} \mathrm{H}_{4}\right), 4.84\left(\mathrm{~d}, \mathrm{~J}=2.07 \mathrm{~Hz}, 1 \mathrm{H}, \mathrm{H}_{3}\right), 6.48$ $\left(\mathrm{s}, 2 \mathrm{H}, \mathrm{H}_{2^{\prime}}, \mathrm{H}_{6^{\prime}}\right), 6.77\left(\mathrm{~s}, 1 \mathrm{H}, \mathrm{H}_{5^{\prime}}{ }^{\prime}\right), 6.84\left(\mathrm{~s}, 1 \mathrm{H}, \mathrm{H}_{6^{\prime}}{ }^{\prime}\right), 6.92\left(\mathrm{~s}, 1 \mathrm{H}, \mathrm{H}_{2^{\prime}}{ }^{\prime}\right) .{ }^{13} \mathrm{C} \mathrm{NMR}(101 \mathrm{MHz}$, $\left.\mathrm{CDCl}_{3}\right) \delta \mathrm{ppm}-1.5\left(\mathrm{Si}-\mathrm{CH}_{3}\right), 25.54\left(\mathrm{CH}_{3}\right), 30.64\left(\mathrm{Si}-\mathrm{C}-\mathrm{CH}_{3}\right), 49.81\left(\mathrm{C}_{3}\right)$ 55.96, 60.88, 66.04 $\left(\mathrm{OCH}_{3}\right), 95.33\left(\mathrm{C}_{2^{\prime}}, \mathrm{C}_{6^{\prime}}\right), 112.41\left(\mathrm{C}_{5^{\prime}}{ }^{\prime}\right), 119.89\left(\mathrm{C}_{3^{\prime}}{ }^{\prime}\right), 126.98\left(\mathrm{C}_{6^{\prime}}{ }^{\prime}\right), 127.25\left(\mathrm{C}_{2^{\prime}}{ }^{\prime}\right), 132.79\left(\mathrm{C}_{4^{\prime}}\right)$, $132.98\left(\mathrm{C}_{1^{\prime}}{ }^{\prime}\right), 134.98\left(\mathrm{C}_{1^{\prime}}{ }^{\prime}\right), 153.43\left(\mathrm{C}_{3^{\prime}}, \mathrm{C}_{5^{\prime}}\right), 160.91\left(\mathrm{C}_{4^{\prime}}{ }^{\prime}\right), 170.39\left(\mathrm{C}_{2}, \mathrm{C}=\mathrm{O}\right)$. HRMS: $[\mathrm{M}+\mathrm{H}]^{+}$ calculated for $\mathrm{C}_{25} \mathrm{H}_{35} \mathrm{BrNO}_{5} \mathrm{Si}, 536.1468$; found 536.1456.

3-Bromo-4-(3-hydroxy-4-methoxyphenyl)-1-(3,4,5-trimethoxyphenyl) azetidin-2-one (16j)

Compound 16i was deprotected with tert-butylammonium fluoride $(t$-BAF) using the method as described above for compound 10n to afford the product as a red oil; 32\%, $13 \mathrm{mg}$, HPLC: $100 \%$. IR V $\max$ (ATR): 3502.80, $1719.42 \mathrm{~cm}^{-1}\left(\mathrm{OH}, \mathrm{C}=\mathrm{O} \beta\right.$-lactam). ${ }^{1} \mathrm{H}$ NMR $\left(400 \mathrm{MHz} \mathrm{CDCl}_{3}\right) \delta \mathrm{ppm} 3.70\left(\mathrm{~s}, 3 \mathrm{H}, \mathrm{OCH}_{3}\right), 3.89\left(\mathrm{~s}, 9 \mathrm{H}, \mathrm{OCH}_{3}\right), 4.58(\mathrm{~d}, \mathrm{~J}=2.07 \mathrm{~Hz}$, $\left.1 \mathrm{H}, \mathrm{H}_{4}\right), 4.86\left(\mathrm{~d}, \mathrm{~J}=2.07 \mathrm{~Hz}, 1 \mathrm{H}, \mathrm{H}_{3}\right), 6.27(\mathrm{~s}, 1 \mathrm{H}, \mathrm{OH}), 6.52\left(\mathrm{~s}, 2 \mathrm{H}, \mathrm{H}_{5^{\prime}}{ }^{\prime}, \mathrm{H}_{6^{\prime}}{ }^{\prime}\right), 6.87(\mathrm{~d}$, $\left.J=4.98 \mathrm{~Hz}, 1 \mathrm{H}, \mathrm{H}_{5^{\prime}}{ }^{\prime}\right) 6.92\left(\mathrm{~d}, J=2.07 \mathrm{~Hz}, 1 \mathrm{H}, \mathrm{H}_{6^{\prime}}{ }^{\prime}\right) 6.96\left(\mathrm{~s}, 1 \mathrm{H}, \mathrm{H}_{2^{\prime}}{ }^{\prime}\right) .{ }^{13} \mathrm{C} \mathrm{NMR}(100 \mathrm{MHz}$, $\left.\mathrm{CDCl}_{3}\right) \delta$ ppm $49.67\left(\mathrm{C}_{3}\right)$, 56.07, $60.46\left(\mathrm{OCH}_{3}\right), 63.65\left(\mathrm{C}_{4}\right), 95.36\left(\mathrm{C}_{2^{\prime}}, \mathrm{C}_{6^{\prime}}\right), 111.09\left(\mathrm{C}_{5^{\prime}}{ }^{\prime}\right)$, $113.19\left(\mathrm{C}_{2^{\prime}}{ }^{\prime}\right), 118.14\left(\mathrm{C}_{6^{\prime}}{ }^{\prime}\right), 125.48\left(\mathrm{C}_{4^{\prime}}\right), 132.90\left(\mathrm{C}_{1^{\prime}}\right), 137.23\left(\mathrm{C}_{1^{\prime}}{ }^{\prime}\right), 146.48\left(\mathrm{C}_{3^{\prime}}{ }^{\prime}\right), 146.68\left(\mathrm{C}_{4^{\prime}}{ }^{\prime}\right)$, $153.51\left(\mathrm{C}_{3^{\prime}}, \mathrm{C}_{5^{\prime}}\right), 176.45\left(\mathrm{C}_{2}, \mathrm{C}=\mathrm{O}\right)$. HRMS: $[\mathrm{M}+\mathrm{H}]^{+}$calculated for $\mathrm{C}_{19} \mathrm{H}_{21} \mathrm{BrNO}_{6}, 438.0554$; found 438.0546 .

3.1.4. 5-(3,3-Dichloro-1-(3,4,5-trimethoxyphenyl)-4-oxoazetidin-2-yl)-2-methoxyphenyl dibenzyl phosphate (17)

Carbon tetrachloride $(85 \mathrm{mmol})$ was added to a solution of phenol 11n $(17 \mathrm{mmol})$ in acetonitrile $\left(100 \mathrm{~mL}\right.$ cooled to $\left.0{ }^{\circ} \mathrm{C}\right)$. The resulting solution was stirred for $10 \mathrm{~min}$, then diisopropylethylamine $(35 \mathrm{mmol})$ and dimethylaminopyridine $(1.7 \mathrm{mmol})$ were added, followed by a dropwise addition of dibenzyl phosphate $(24.5 \mathrm{mmol})$. When the reaction was complete, $0.5 \mathrm{M} \mathrm{KH}_{2} \mathrm{PO}_{4}(\mathrm{aq})$ was added, and the mixture was allowed to warm to room temperature. An ethyl acetate extract $(3 \times 50 \mathrm{~mL})$ was washed with saturated sodium chloride solution $(100 \mathrm{~mL})$ followed by water $(100 \mathrm{~mL})$ and the mixture was dried using anhydrous sodium sulfate. The solvent was reduced in vacuo and the product was isolated using flash column chromatography over silica gel (eluent, $n$-hexane: ethyl acetate gradient). Yield: $66 \%, 326 \mathrm{mg}$, brown oil. IR ( NaCl, film) $\mathrm{V}_{\max }: 2945,1748$ (C=O, $\beta$-lactam), 1605, 1507, $1321(\mathrm{P}=\mathrm{O}), 1237 \mathrm{~cm}^{-1} .{ }^{1} \mathrm{H} \mathrm{NMR}\left(400 \mathrm{MHz}, \mathrm{CDCl}_{3}\right): \delta 3.72\left(\mathrm{~s}, 6 \mathrm{H}, \mathrm{OCH}_{3}\right), 3.78$ $\left(\mathrm{s}, 3 \mathrm{H}, \mathrm{OCH}_{3}\right), 3.83\left(\mathrm{~s}, 3 \mathrm{H}, \mathrm{OCH}_{3}\right), 5.12-5.18\left(\mathrm{~m}, 4 \mathrm{H}\left(\mathrm{OCH}_{2} \mathrm{Ph}\right)_{2}\right), 5.36\left(\mathrm{~s}, 1 \mathrm{H}, \mathrm{H}_{4}\right), 6.53$ $\left(\mathrm{s}, 2 \mathrm{H}, \mathrm{H}_{2^{\prime}}, \mathrm{H}_{6^{\prime}}\right), 6.96-7.19\left(\mathrm{~m}, 3 \mathrm{H}, \mathrm{H}_{2^{\prime}}{ }^{\prime}, \mathrm{H}_{5^{\prime}}{ }^{\prime}, \mathrm{H}_{6^{\prime}}{ }^{\prime}\right), 7.31-7.36$ (m, 10H, Ar-H). ${ }^{13} \mathrm{C} \mathrm{NMR}$ $\left(100 \mathrm{MHz}_{\mathrm{CDCl}}\right): \delta 55.52,55.72,60.52\left(\mathrm{OCH}_{3}\right), 69.57,69.60,69.65\left(\mathrm{OPO}\left(\mathrm{OCH}_{2} \mathrm{Ph}\right)_{2}\right), 73.04$ $\left(\mathrm{C}_{4}\right), 83.57\left(\mathrm{C}_{3}\right), 95.36\left(\mathrm{C}_{2^{\prime}}, \mathrm{C}_{6^{\prime}}\right), 112.27\left(\mathrm{C}_{5^{\prime}}{ }^{\prime}\right), 120.87\left(\mathrm{C}_{2^{\prime}}{ }^{\prime}\right), 124.82\left(\mathrm{C}_{6^{\prime}}{ }^{\prime}\right), 127.42,127.53$, $128.17,128.20,128.27,131.27\left(\mathrm{C}_{4^{\prime}}\right), 134.93,135.00,135.27,139.40,151.48,153.22\left(\mathrm{C}_{3^{\prime}}, \mathrm{C}_{5^{\prime}}\right)$, $157.77\left(\mathrm{C}_{2}\right)$. HRMS: found $710.1107[\mathrm{M}+\mathrm{Na}]^{+} ; \mathrm{C}_{33} \mathrm{H}_{32}{ }^{35} \mathrm{Cl}_{2} \mathrm{NO}_{9} \mathrm{PNa}$ requires 710.1089 .

3.1.5. 5-(3,3-Dichloro-1-(3,4,5-trimethoxyphenyl)-4-oxoazetidin-2-yl)-2-methoxyphenyl dihydrogen phosphate (18)

The dibenzylphosphate ester 17 ( $2 \mathrm{mmol})$ was dissolved in ethanol:ethyl acetate (50 mL; 1:1 mixture) and hydrogenated over $1.2 \mathrm{~g}$ of $10 \%$ palladium on carbon until reaction was complete, as monitored by TLC (approximately $3 \mathrm{~h}$ ). The catalyst was filtered, the solvent was reduced in vacuo and the product isolated using flash column chromatography over silica gel (eluent, $n$-hexane: ethyl acetate gradient). Yield: 75\%, $213 \mathrm{mg}$, brown oil. IR (NaCl, film) $\mathrm{V}_{\text {max }}: 3429(\mathrm{OH}), 1778\left(\mathrm{C}=\mathrm{O}, \beta\right.$-lactam), $1298(\mathrm{P}=\mathrm{O}), 1240,1128 \mathrm{~cm}^{-1}$. ${ }^{1} \mathrm{H}$ NMR $\left(400 \mathrm{MHz} \mathrm{CDCl}_{3}\right): \delta 3.66\left(\mathrm{~s}, 9 \mathrm{H}, \mathrm{OCH}_{3}\right), 3.73\left(\mathrm{~s}, 3 \mathrm{H}, \mathrm{OCH}_{3}\right), 5.45\left(\mathrm{~s}, 1 \mathrm{H}, \mathrm{H}_{4}\right), 6.52(\mathrm{~s}, 2 \mathrm{H}$, $\left.\mathrm{H}_{2^{\prime}}, \mathrm{H}_{6^{\prime}}\right), 6.88-7.38\left(\mathrm{~m}, 3 \mathrm{H}, \mathrm{H}_{2^{\prime}}{ }^{\prime}, \mathrm{H}_{5^{\prime}}{ }^{\prime} \mathrm{H}_{6^{\prime}}{ }^{\prime}\right) .{ }^{13} \mathrm{C} \mathrm{NMR}\left(100 \mathrm{MHz}, \mathrm{CDCl}_{3}\right): \delta 55.48,55.72$, 
$60.46\left(\mathrm{OCH}_{3}\right), 72.86\left(\mathrm{C}_{4}\right), 83.48\left(\mathrm{C}_{3}\right), 95.52\left(\mathrm{C}_{2^{\prime}}, \mathrm{C}_{6^{\prime}}\right), 112.12\left(\mathrm{C}_{5^{\prime}}{ }^{\prime}\right), 120.79\left(\mathrm{C}_{2^{\prime}}{ }^{\prime}\right), 124.22\left(\mathrm{C}_{6^{\prime}}{ }^{\prime}\right)$, $127.86\left(\mathrm{C}_{4^{\prime}}\right), 131.16\left(\mathrm{C}_{1^{\prime}}\right), 135.05\left(\mathrm{C}_{1^{\prime}}{ }^{\prime}\right), 140.03\left(\mathrm{C}_{3^{\prime}}\right), 151.08\left(\mathrm{C}_{4^{\prime}}{ }^{\prime}\right), 153.10\left(\mathrm{C}_{3^{\prime}}, \mathrm{C}_{5^{\prime}}\right), 157.79$ $\left(\mathrm{C}_{2}\right)$. HRMS: found $506.0200[\mathrm{M}-\mathrm{H}]^{-} ; \mathrm{C}_{19} \mathrm{H}_{19}{ }^{35} \mathrm{Cl}_{2} \mathrm{NO}_{9} \mathrm{P}$ requires 506.0174.

\subsection{Stability Study for Compound 16a}

A stability study for compound 16a was performed by analytical HPLC using a Symmetry ${ }^{\circledR}$ column $(\mathrm{C} 18,5 \mathrm{~mm}, 4.6 \times 150 \mathrm{~mm})$, a Waters 2487 Dual Wavelength Absorbance detector, a Waters 1525 binary HPLC pump and a Waters 717 plus Autosampler (Waters Corporation, Milford, MA, USA). Samples were detected at $\lambda 254 \mathrm{~nm}$ using acetonitrile $(70 \%)$ / water $(30 \%)$ as the mobile phase over $15 \mathrm{~min}$ and a flow rate of $1 \mathrm{~mL} / \mathrm{min}$. A stock solution of the compound was prepared using $10 \mathrm{mg}$ of compound $16 \mathrm{a}$ in $10 \mathrm{~mL}$ of mobile phase $(1 \mathrm{mg} / \mathrm{mL})$. A calibration curve was prepared using a solution of 0.5 , $0.25,0.125,0.0625,0.03125,0.015625$ and $0.0078 \mathrm{mg} / \mathrm{mL}$. (i) Stability of $16 a$ in phosphate buffers: Phosphate buffers at $\mathrm{pH}$ values 4, 7.4 and 9 were prepared according to the British Pharmacopoeia 2020. A total of $300 \mu \mathrm{L}$ of stock solution $(1 \mathrm{mg} / \mathrm{mL}$ ACN) for 16a was added to a vial containing $9.7 \mathrm{~mL}$ of buffer, mixed and pre-heated to $37^{\circ} \mathrm{C}$. A total of $1 \mathrm{~mL}$ of the solution was added to the HPLC glass vial and $10 \mu \mathrm{L}$ was injected, followed by hourly injections for a 24-h period. Samples were withdrawn and analysed at time intervals of $\mathrm{t}=0 \mathrm{~min}, 5 \mathrm{~min}, 30 \mathrm{~min}, 60 \mathrm{~min}$ and hourly for $24 \mathrm{~h}$. The analysis was performed in triplicate. (ii) Thermal stability: 16a $(1 \mathrm{mg})$ was placed in a vial (for the solution, $1 \mathrm{~mL}$ of stock solution was used) at $60{ }^{\circ} \mathrm{C}$ for $4 \mathrm{~h}$ on a heating block. The sample was then cooled, diluted with ACN and analysed using HPLC. (iii) Photostability study: A solution of compound 16a (1 mL of the stock solution) was placed in a vial and exposed to UV light for $4 \mathrm{~h}$. The sample was directly analysed using HPLC. (iv) Stability in acidic condition: The stock solutions $(0.8 \mathrm{~mL})$ of 16 a were placed in a vial and $\mathrm{HCl}(0.1 \mathrm{M}, 0.2 \mathrm{~mL})$ was added. The vial was vortexed to ensure a homogeneous mixture and left to stand at room temperature. A sample from the vial was taken and neutralised with $\mathrm{NaOH}(0.1 \mathrm{M}, 0.2 \mathrm{~mL})$ every hour for $4 \mathrm{~h}$. Once neutralised, the samples were analysed using HPLC. (v) Stability of $16 a$ in basic (alkaline) conditions: The stock solution $(0.8 \mathrm{~mL})$ was placed in a vial and $\mathrm{NaOH}(0.1 \mathrm{M}, 0.2 \mathrm{~mL})$ was added. The vial was vortexed to ensure a homogeneous mixture and left to stand at room temperature. A sample from the vial was neutralised with $\mathrm{HCl}$ $(0.1 \mathrm{M}, 0.2 \mathrm{~mL})$ every hour for the $4 \mathrm{~h}$. Once neutralised, the samples were analysed using HPLC. (vi) Stability of $\mathbf{1 6} a$ in oxidising conditions: The stock solution $(0.8 \mathrm{~mL})$ was placed in a vial and $\mathrm{H}_{2} \mathrm{O}_{2}(3 \%, 0.2 \mathrm{~mL})$ was added. The vial was vortexed to ensure a homogeneous mixture and left to stand for $4 \mathrm{~h}$ at room temperature. A sample from the vial was taken every hour over $4 \mathrm{~h}$ and analysed using HPLC.

\subsection{Biochemical Evaluation of Activity}

All biochemical assays were performed in triplicate on at least three independent occasions for the determination of mean values reported. All the reagents including foetal bovine serum (FBS) and cell culture growth medium (MEM, DMEM and RPMI-1640) were purchased from BD Biosciences. CA-4 was purchased from Sigma Aldrich.

\subsubsection{Cell Culture}

The human breast carcinoma cell line MCF-7 was purchased from the European Collection of Animal Cell Cultures (ECACC). Triple negative breast cancer Hs578T cells and its invasive variant Hs578Ts(i)8 were a kind gift from Dr. Susan McDonnell, School of Chemical and Bioprocess Engineering, University College Dublin. U266 cells were a gift from Dr. Tony McElligott, School of Medicine, St James's Hospital, Trinity College Dublin. HT-29 cells were purchased from the European Collection of Cell Cultures (originating from a human adenocarcinoma of the colon). The human breast carcinoma cell line MDA-MB-231 and the HL-60 cells derived from a patient with acute myeloid leukaemia were both obtained from ECACC (Salisbury, UK). The SW-480 cells were a kind gift from Dr. Brian Flood, School of Biochemistry and Immunology, Trinity College Dublin. HEK-293T (normal 
epithelial embryonic kidney cells) were cultured in Dulbecco's Modified Eagle's Medium (DMEM) with GlutaMAXTM-I in the absence of non-essential amino acids. Human breast cancer MCF-7 cells and multiple myeloma U266 cells were cultured in Minimum Essential Media (MEM) with GlutaMAX ${ }^{\mathrm{TM}}-\mathrm{I}$, supplemented with $1 \%(v / v)$ non-essential amino acids, $10 \% 2(v / v)$ foetal bovine serum (FBS) and $1 \%(v / v)$ penicillin/streptomycin $5000 \mathrm{U} / \mathrm{mL}$. MDA-MB-231 cells were maintained in DMEM supplemented with $10 \%(v / v)$ foetal bovine serum, $2 \mathrm{mM}$ L-glutamine and $100 \mu \mathrm{g} / \mathrm{mL}$ penicillin/streptomycin (complete medium). Colon cancer HT-29 and SW-480 and triple negative breast cancer Hs578T and its invasive variant Hs578T8i were cultured in DMEM with GlutaMAX ${ }^{\mathrm{TM}}$-I, with the same supplement in the absence of non-essential amino acids. Leukaemia HL-60 cancer cells were cultured in Roswell Park Memorial Institute Media (RPMI-1640) with GlutaMAX ${ }^{\mathrm{TM}}-\mathrm{I}$, supplemented with $10 \%$ FCS media, and $100 \mu \mathrm{g} / \mathrm{mL}$ penicillin/streptomycin as above. Cell numbers were monitored using a haemocytometer. Cell culture flasks were incubated in a humidified incubator $\left(5 \% \mathrm{CO}_{2} / 95 \%\right.$ air $)$ at $37^{\circ} \mathrm{C}$. All cell lines were sub-cultured three times per week with trypsinisation using TrypLE Express (1X) required for adherent cell lines.

\subsubsection{Cell Viability Assay}

A stock solution of each $\beta$-lactam compound was prepared $(10 \mathrm{mM})$ and serial $100 \times$ dilutions were made with ethanol for compounds to have working dilutions of $1 \mathrm{nM}$, $10 \mathrm{nM}, 100 \mathrm{nM}, 500 \mathrm{nM}, 1 \mu \mathrm{M}, 5 \mu \mathrm{M}, 10 \mu \mathrm{M}$ and $50 \mu \mathrm{M}$. CA-4 was dissolved in ethanol to obtain a $10 \mathrm{mM}$ stock solution. All stock solutions and serial dilution in ethanol/DMSO were stored at $-20^{\circ} \mathrm{C}$. All cells were seeded at a density of $2.5 \times 10^{4}$ cells $/ \mathrm{mL}$ in a 96 -well plate (200 $\mu \mathrm{L}$ per well). The cells were incubated in a $95 \% \mathrm{O}_{2} / 5 \% \mathrm{CO}_{2}$ atmosphere at $37^{\circ} \mathrm{C}$ for $24 \mathrm{~h}$, then treated with test compound ( $2 \mu \mathrm{L}$ of stock solutions per 200-microlitre well) in ethanol to obtain a concentration range of $1 \mathrm{nM}-200 \mu \mathrm{M}$ for the study. The plates were then re-incubated for a further $72 \mathrm{~h}$. Control wells contained an equivalent volume of the vehicle ethanol or DMSO $(1 \% v / v)$. MTT cell viability assay: The culture medium was removed, and the cells were washed with phosphate buffered saline (PBS, $100 \mathrm{~mL}$ ). MTT (dissolved in PBS, $50 \mathrm{~mL})$ was added to obtain a final concentration of MTT $(1 \mathrm{mg} / \mathrm{mL})$. Cells were incubated at $37^{\circ} \mathrm{C}$ for $3 \mathrm{~h}$ in the dark. Solubilisation was commenced by the addition of DMSO $(200 \mathrm{~mL})$ and the cells were maintained at $20^{\circ} \mathrm{C}$ in the dark for $20 \mathrm{~min}$ before reading the absorbance to ensure complete colour diffusion. The absorbance value of control cells (no added compound) was set to $100 \%$ cell viability and absorbance versus cell density per well was determined to assess cell viability using Graph-Pad Prism software. AlamarBlue cell viability assay: Cells were seeded in 96-well plates (e.g., MCF-7, $5 \times 10^{3}$ cells/well) and (HT-29 cells, $1 \times 10^{3}$ cells/well) and (HL-60 cells, $1 \times 10^{4}$ cells/well) with a total volume per well of $200 \mu \mathrm{L}$. After $24 \mathrm{~h}$, cells were treated in triplicate with serial dilutions of CA-4 or $\beta$-lactam analogues $(0.001-100 \mu \mathrm{M})$, medium alone or vehicle $(1 \%$ ethanol $(v / v))$. Ethanol or DMSO were used as vehicle control and cells were treated with no more than $1 \%$ ethanol $(v / v)$ or $0.1 \%$ DMSO in all experiments. Cell proliferation for cells was analysed using the AlamarBlue assay (Invitrogen Corp.) following the manufacturer's instructions. After $72 \mathrm{~h}$, AlamarBlue $(10 \%(v / v)(20 \mu \mathrm{L}))$ was added to each well and plates were incubated in the dark at $37^{\circ} \mathrm{C}$ for $3-5 \mathrm{~h}$. The blank consisted of the appropriate medium (according to cell type) with the addition of AlamarBlue. Plates were analysed on the 96-well fluorimeter Spectramax Gemini plate reader with excitation at $530 \mathrm{~nm}$ and emission at $590 \mathrm{~nm}$ using a SOFTmax Pro version 4.9 (Molecular Devices, Sunnyville, C.A) software package and the percentage viability relative to vehicle control was recorded. Results were plotted using GraphPad Prism 5 software and analysed using a non-liner, sigmoidal dose response curve to determine the relative $\mathrm{IC}_{50}$ values. All assays were performed in triplicate for the determination of mean values reported.

\subsubsection{Lactate Dehydrogenase Assay for Cytotoxicity}

The cytotoxicity of selected compounds was determined using the CytoTox 96 nonradioactive cytotoxicity assay (Promega Corporation, Madison, WI, USA) [104]. Briefly, MCF- 
7 cells were seeded in a 96-well plate ( $200 \mu \mathrm{L}$ per well), at a density of $2.5 \times 10^{4}$ cells $/ \mathrm{mL}$, and incubated for $24 \mathrm{~h}$. The cells were then treated with selected $\beta$-lactam compounds as described above for the cell viability assay. After $72 \mathrm{~h}$, 'lysis solution $(10 \mathrm{X})^{\prime}(20 \mu \mathrm{L})$ was added to the plate and incubated for a further $1 \mathrm{hr}$ to ensure $100 \%$ death. Supernatant $(50 \mu \mathrm{L})$ was removed from each well to a 96-well plate. Reconstituted 'CytoTox $96{ }^{\circledR}$ Reagent $(50 \mu \mathrm{L})$ was added to each well and the plate was placed in the dark at $20^{\circ} \mathrm{C}$ for $30 \mathrm{~min}$. 'Stop solution' $(50 \mu \mathrm{L})$ was added to each well and the samples were analysed at $490 \mathrm{~nm}$ using a Dynatech MR5000 plate reader. The percentage cell death at $10 \mu \mathrm{M}$ was calculated.

\subsubsection{Cell Cycle Analysis}

Flow cytometric analysis was used to determine DNA level in any given cell that had been stained with propidium iodide (PI) [105]. In this experiment, adherent and detached cells were collected by trypsinisation and centrifuged at $800 \times g$ for $15 \mathrm{~min}$. Cells were then washed three times with ice-cold PBS and fixed with slow addition of ice-cold $70 \%$ ethanol overnight at $-20{ }^{\circ} \mathrm{C}$. The cells were then centrifuged $(800 \times g)$ for $15 \mathrm{~min}$; the pellet was re-suspended in PBS $(400 \mu \mathrm{L})$ and transferred to LP5 FACS tubes. Cells were then stained with PI $(50 \mu \mathrm{g} / \mathrm{mL})$, containing DNase-free RNase A $(50 \mu \mathrm{g} / \mathrm{mL})$ at $37^{\circ} \mathrm{C}$ for $30 \mathrm{~min}$, which degrades any double-strand RNA. The DNA content of the cells (10,000 cells/experimental group) was analysed by flow cytometry at $488 \mathrm{~nm}$ using a FACSCalibur flow cytometer (BD Biosciences, San Jose, CA, USA). Results were presented as mean \pm SEM. The statistical analysis of experimental data was performed using the program Prism GraphPad 5. A two-way ANOVA (Bonferroni post-test) was used to test for statistical significance $\left.{ }^{* *}, p<0.05,{ }^{* * *}, p<0.001\right)$. A value of $p<0.05$ was considered to be significant.

\subsubsection{Annexin V/PI Apoptotic Assay}

The Annexin V/Propidium Iodide (PI) assay was used to detect both early- and late-stage apoptosis using flow cytometry, as previously reported [34]. Early apoptosis is detected by the presence of phosphatidylserine (PS) on the outer surface of the cell membrane. PS is a phospholipid normally found on the cytoplasmic surface of the cell membrane. In apoptosis, PS is translocated to the outer surface of the cell membrane, and is exposed to the extracellular environment [106]. MCF-7 cells were seeded in 6-well plates $\left(1 \times 10^{5}\right.$ cells $\left./ \mathrm{mL}\right)$ and treated with either vehicle $(0.1 \%(v / v) \mathrm{EtOH}), \mathrm{CA}-4(50 \mathrm{nM})$ or $\beta$-lactam compound 10n (50 and $500 \mathrm{nM})$ for $48 \mathrm{~h}$. Cells were then analysed using flow cytometry. Cells were first washed in $1 \mathrm{X}$ binding buffer (20X binding buffer: $0.1 \mathrm{M}$ HEPES, pH 7.4; $1.4 \mathrm{M} \mathrm{NaCl} ; 25 \mathrm{mM} \mathrm{CaCl}_{2}$ diluted in $\mathrm{dH}_{2} \mathrm{O}$ ) and treated for $30 \mathrm{~min}$ on ice in Annexin V-containing binding buffer (1:100) in the dark. Cells were washed in binding buffer and then re-suspended in PI-containing binding buffer (1:1000). Samples were analysed without delay using the BD Accuri flow cytometer and the data analysed with GraphPad Prism software.

\subsubsection{In Vitro Tubulin Polymerisation Assay}

The assembly of purified bovine tubulin was monitored using a kit, BK006, purchased from Cytoskeleton Inc. (Denver, CO, USA) [89] as we have previously reported [34]. Briefly, purified bovine brain tubulin $(>99 \%, 3 \mathrm{mg} / \mathrm{mL}$ ) in a buffer ( $80 \mathrm{mM}$ PIPES $(\mathrm{pH} 6.9), 0.5 \mathrm{mM}$ EGTA, $2 \mathrm{mM} \mathrm{MgCl} 2,1 \mathrm{mM}$ GTP and $10 \%$ glycerol) was incubated at $37^{\circ} \mathrm{C}$ in the presence of either vehicle $\left(2 \%(v / v) \mathrm{ddH}_{2} \mathrm{O}\right)$ or $\beta$-lactam compounds 10e and 11n $(10 \mu \mathrm{M})$. A reference control experiment with CA- 4 was also used (See Supplementary information). Light was scattered proportionally, dependent on the concentration of polymerised microtubules in the sample. Tubulin assembly was monitored turbidimetrically at $37^{\circ} \mathrm{C}$ in a Spectramax 340 PC spectrophotometer (Molecular Devices, Sunnyvale, CA, USA) at $340 \mathrm{~nm}$. The absorbance was measured at 30-s intervals for $60 \mathrm{~min}$. 


\subsubsection{Colchicine Binding-Site Assay}

The assay was performed as we have previously reported [74]. N,N'-Ethylenebis(iodoacetamide) (EBI) (Santa Cruz Biotechnology) was dissolved in ethanol (100 $\mu \mathrm{M})$. MCF-7 cells were seeded at a density of $5 \times 10^{4}$ cells/well in 6-well plates and incubated overnight. Cells were treated with vehicle control (ethanol $(0.1 \% v / v)$ ), colchicine or CA-4 and selected $\beta$-lactam compound (all $10 \mu \mathrm{M}$ ) for $2 \mathrm{~h}$. After this time, selected wells were treated with EBI $(100 \mu \mathrm{M})$ for $1.5 \mathrm{~h}$. Following treatment, cells were twice washed with icecold PBS and lysed by addition of Laemmli buffer. Samples were separated by SDS-PAGE, transferred to polyvinylidene difluoride (PVDF) membranes, and probed with $\beta$-tubulin antibodies (Sigma Aldrich, Milwaukee, WI, USA) as previously described [74,93].

\subsubsection{Immunofluorescence Assay}

Confocal microscopy was used to study the effects on MCF-7 cytoskeleton following treatment with compound 10n following the protocols previously reported [34]. For each experiment, all images were collected on the same day using identical parameters. MCF-7 cells were seeded $\left(1 \times 10^{5}\right.$ cells $\left./ \mathrm{mL}\right)$ on eight chamber glass slides. Cells were either untreated or treated with vehicle $(1 \%$ ethanol $(v / v))$, CA-4 $(0.05 \mu \mathrm{M})$, Paclitaxel $(1 \mu \mathrm{M})$ and $\beta$-lactam compound 10 $\mathrm{n}$ at $0.05,0.1$ and $0.5 \mu \mathrm{M}$ concentrations for $16 \mathrm{~h}$. The cells were then gently washed in PBS, fixed for $30 \mathrm{~min}$ with $100 \%$ ice-cold MeOH. Cells were washed three times in PBS for $10 \mathrm{~min}$ and then permeabilised in $0.5 \%$ Triton X-100. The cells were subsequently washed in PBS containing $0.1 \%$ Tween (PBST), blocked in bovine serum albumin (5\%) diluted in PBST. Cells were then incubated with a mouse monoclonal anti- $\alpha-$ tubulin-FITC antibody (clone DM1A) (1:200) for $2 \mathrm{~h}$ at $20^{\circ} \mathrm{C}$. Following washes in PBST, cells were incubated with Alexa Fluor 488 dye (1:500) for $1 \mathrm{~h}$ at $20^{\circ} \mathrm{C}$. Following further washes in PBST, the cells were mounted in Ultra Cruz Mounting Media, which contained 4,6-diamino-2-phenolindol dihydrochloride (DAPI). The images were photographed using Leica SP8 confocal microscopy with Leica application suite X software. Experiments were performed on three independent occasions.

\subsubsection{Western Blot Analysis}

MCF-7 cells were seeded at a density of $1 \times 10^{5}$ cells / flask in T25 flasks. After $48 \mathrm{~h}$, whole cell lysates were prepared from untreated cells or cells treated with vehicle control (Ethanol, $0.1 \% v / v)$ or compound 10n $(0.05,0.1$ and $0.5 \mu \mathrm{M})$. MCF-7 cells were harvested in RIPA buffer supplemented with protease inhibitors (Roche Diagnostics), phosphatase inhibitor cocktail 2 (Sigma-Aldrich, St. Louis, MI, USA), and phosphatase inhibitor cocktail 3 (Sigma-Aldrich). Equal quantities of protein (as determined using a BCA assay) were resolved by SDS-PAGE (12\%) followed by transfer to PVDF membranes. Membranes were blocked for $1 \mathrm{~h}$ using 5\% bovine serum albumin/TBST then incubated in the relevant primary antibodies at $4{ }^{\circ} \mathrm{C}$ overnight. Membranes were washed with TBST, incubated in horseradish peroxidase conjugated secondary antibody for $1 \mathrm{~h}$ at room temperature and washed again. Western blot analysis, using antibodies directed against Bcl-2 (1:500) (Millipore), BAX (1:1000) (Millipore) or Mcl-1 (1:1000) (Millipore), was followed by incubation with a horseradish peroxidase-conjugated anti-mouse antibody [1:2000] (Promega, Madison, WI, USA). Blots were probed with anti-GAPDH antibody (1:5000) (Millipore) to confirm equal loading. Proteins were detected using enhanced chemiluminescent Western blot detection (Clarity Western ECL substrate) (Bio Rad) on the ChemiDoc MP System (Bio Rad). Experiments were performed on two independent occasions.

\subsection{X-ray Crystallography}

Data for samples 9o, 10o/16g and 11o were collected on a Bruker APEX DUO using Mo $K \alpha$ radiation $(\lambda=0.71073 \AA)$. Each sample was mounted on a MiTeGen cryoloop and data was collected at 100(2) K using an Oxford Cobra cryosystem. Bruker APEX software [107] was used to collect and reduce data, determine the space group and solve and refine the structures. Absorption corrections were applied using SADABS [108]. 
Data for 10e were collected on a Rigaku Saturn 724 (Mo K $\alpha$ radiation, $\lambda=0.71073 \AA$ ) equipped with a Rigaku X-Stream low temperature device. The sample was mounted on a Hampton cryoloop and data were collected at 93(2) K. Data were measured using $0.3^{\circ}$ scans per frame for $20 \mathrm{~s}$. A total of 852 frames were collected with a final resolution of $0.77 \AA$. Data reduction and correction for Lorenz, polarisation and absorption were performed using the CrystalClear software. Absorption corrections were applied using REQAB (Rigaku Inc., 2007). Structures 10o/16g and 11o were solved with the SHELXT structure solution program [109] using Intrinsic Phasing and 9o and 10e with SHELXS with direct methods. All were refined using Least Squares method on $\mathrm{F}^{2}$ with SHELXL. All non-hydrogen atoms were refined anisotropically. Hydrogen atoms were assigned to calculated positions using a riding model with appropriately fixed isotropic thermal parameters. Molecular graphics were generated using OLEX2 [110]. In the structure of 10o, the halogen substituted 3 position on the lactam ring was modelled between $\mathrm{Cl}$ and $\mathrm{Br}$ with $75: 25 \%$ of each, respectively. The occupancy was freely refined then fixed. $\mathrm{C}-\mathrm{Cl}$ and $\mathrm{C}-\mathrm{Br}$ distances were restrained (DFIX) and the atomic displacement of both halides was also constrained (EADP). In 11o, the 4 substituent, the $\mathrm{Me}(\mathrm{OMe}) \mathrm{Ph}$ ring, was modelled in two locations with restraints (SADI) and constraints (EADP). The refined occupancies of each moiety were $81: 19 \%$. Crystallographic data for the structures in this paper have been deposited with the Cambridge Crystallographic Data Centre as supplementary publication nos. 2077515-2077518. Copies of the data can be obtained, free of charge, on application to CCDC, 12 Union Road, Cambridge CB2 1EZ, UK (fax: +44-(0)1223-336033 or e-mail: deposit@ccdc.cam.ac.uk).

\subsection{Computational Procedure for Molecular Docking}

The 1SA0 X-ray structure of bovine tubulin co-crystallised with N-deacetyl-N(2-mercaptoacetyl)-colchicine (DAMA-colchicine) was downloaded from the PDB website [6]. A UniProt Align analysis confirmed a 100\% sequence identity between human and bovine $\beta$ tubulin. The crystal structure was prepared using QuickPrep (minimised to a gradient of $0.001 \mathrm{kcal} / \mathrm{mol} / \AA$ ), Protonate 3D, Residue pKa and Partial Charges protocols in MOE 2019 with the MMFF94x force field. Compounds 10n, 11n and 14b were drawn in MOE, saved as an mdb and processed in MOE [101]. Both trans enantiomers of the compounds 10n, 11n and 14b were examined. For each compound, MMFF94x partial charges were calculated, and each was minimised to a gradient of $0.001 \mathrm{kcal} / \mathrm{mol} / \AA$. Default parameters were used for docking except that 300 poses were sampled for each compound and the top 50 docked poses were retained for subsequent analysis. Default settings of OMEGA [111,112] were used to generate 50 conformers of each compound prior to running rigid docking with FRED [113], included in the OEDocking suite [111].

\section{Conclusions}

Microtubule-targeting drugs such as taxanes and vinca alkaloids are very effective therapeutic agents in the treatment of various types of cancers. Interestingly, the antiviral activity of the bis-indole microtubule targeting drug sabizabulin (VERU-111) against SARS CoV-2 was recently reported [114]. Sabizabulin binds to tubulin and disrupts the intracellular transport of the SARS CoV-2 virus; it also demonstrates an effective anti-inflammatory effect. In this work, a novel series of heterocyclic combretastatin CA-4 compounds based on the $\beta$-lactam scaffold were designed and synthesised as tubulin-targeting agents. All the novel compounds were initially evaluated in the MCF-7 breast cancer cell line and of particular interest were compounds 10e, 10n and 11n, which displayed antiproliferative activity in the nanomolar range, e.g., $10 e\left(\mathrm{IC}_{50}=34 \mathrm{nM}\right), \mathbf{1 0 n}\left(\mathrm{IC}_{50}=17.5 \mathrm{nM}\right)$ and $\mathbf{1 1 n}$ $\left(\mathrm{IC}_{50}=31 \mathrm{nM}\right)$ in MCF-7 cells. These compounds were identified for further studies to provide a better understanding of their mechanism of action in breast cancer cells. Minimal cytotoxicity was observed on the treatment of the most potent compound 10n in the nontumourigenic cell line HEK-293T, demonstrating the selectivity of the compounds toward cancer cells. The compounds were evaluated in the NCI 60 cancer cell line panel and 
demonstrated significant antiproliferative activity at nanomolar concentrations in a range of human cancer cell lines. Cell cycle analysis of compound 10n in MCF-7 cells demonstrated that this compound induces $\mathrm{G}_{2} / \mathrm{M}$ arrest and apoptotic cell death. The induction of apoptosis in MCF-7 cells by compound 10n was confirmed using flow cytometric analysis of Annexin V/PI-stained cells. An alteration of the expression levels of apoptosis-related proteins Bax, Bcl-2 and Mcl-1 in MCF-7 cells was shown using Western blot analysis. To examine whether the antiproliferative activities might be related to the depolymerisation of tubulin, the inhibitory effects of compounds $10 \mathrm{e}$ and $\mathbf{1 1 n}$ on tubulin polymerisation were confirmed with the suppression of in vitro tubulin polymerisation. The tubulin depolymerisation effects of compound 10n were confirmed when MCF-7 cells treated with the $\beta$-lactam 10n displayed a disorganised microtubule network with similar multinucleation effects to CA-4. Tubulin EBI-adduct formation was inhibited in MCF-7 cells treated with 10n, indicating an interaction with the colchicine binding site of tubulin. Our data strongly indicate that this class of $\beta$-lactams represent interesting lead molecules with the potential for a design of potent microtubule-targeting agents and further clinical anti-cancer drug development.

Supplementary Materials: The following are available online at https:/ /www.mdpi.com/article/ 10.3390/ph14111119/s1: Table S1: Tier-1 Profiling Screen of Selected 3-chloroazetidinones, 3,3-dichloroazetidinones and related compounds; Table S2: ADMET and Lipinski Properties for Selected 3-chloroazetidinones, 3,3-dichloroazetidinones and related compounds; Table S3: Standard COMPARE Analysis of compounds 10e, 11n and 16d; Table S4: Cell cycle analysis of MCF-7 cells following treatment with 10n. Figure S1: Effect of control compound CA-4 on tubulin polymerization in vitro; Figures S2-S21: ${ }^{1} \mathrm{H}$ NMR and ${ }^{13} \mathrm{C}$ NMR spectra.

Author Contributions: Conceptualisation, T.F.G., S.W., A.M.M. and M.J.M.; formal analysis, S.W., A.M.M., B.T., T.M., S.M.N., D.F., N.M.O., T.F.G. and M.J.M.; funding acquisition, A.M.M. and M.J.M.; investigation, S.W., T.F.G., A.M.M., S.M.N., D.F. and M.F.K.: methodology, S.W., A.M.M., D.F., B.T. and S.M.N.; supervision, M.J.M. and D.M.Z.; writing—original draft, M.J.M., S.W. and A.M.M.; writing - review and editing, M.J.M., A.M.M., N.M.O., D.M.Z. and D.F. All authors have read and agreed to the published version of the manuscript.

Funding: The research conducted in this publication was jointly funded by the Irish Research Council under grant number GOIPD/2020/615 (MFK), a postgraduate research scholarship from King Abdulaziz University (KAU), Ministry of 1871 Higher Education, Kingdom of Saudi Arabia (Ref. IRKA1001; AMM) and by Postgraduate research scholarships from Trinity College Dublin (S.W., T.F.G.).

Institutional Review Board Statement: Not applicable.

Informed Consent Statement: Not applicable.

Data Availability Statement: Data sharing not applicable.

Acknowledgments: The Trinity Biomedical Sciences Institute (TBSI) is supported by a capital infrastructure investment from Cycle 5 of the Irish Higher Education Authority's Programme for Research in Third Level Institutions (PRTLI). A postgraduate research scholarship from King Abdulaziz University (KAU), Ministry of Higher Education, Saudi Arabia (Ref. IRKA1001; AMM) and the Irish Re-search Council grant number GOIPD/2020/615 (MFK) are gratefully acknowledged. This study was also co-funded under the European Regional Development and Trinity College Dublin post-graduate research award (SW and TFG). We thank Gavin McManus for assistance with confocal microscopy, Barry Moran for assistance with flow cytometry and Gabriela Duffy Morales for syn-thetic and analytical contribution. We thank John O'Brien and Manuel Ruether for NMR spectra. D.F. thanks the software vendors for their continuing support of academic research efforts, in particular the contributions of the Chemical Computing Group, Biovia and OpenEye Scientific. The support and provisions of Dell Ireland, the Trinity Centre for High Performance Computing (TCHPC) and the Irish Centre for High-End Computing (ICHEC) are also gratefully acknowl-edged.

Conflicts of Interest: The authors declare no conflict of interest. 


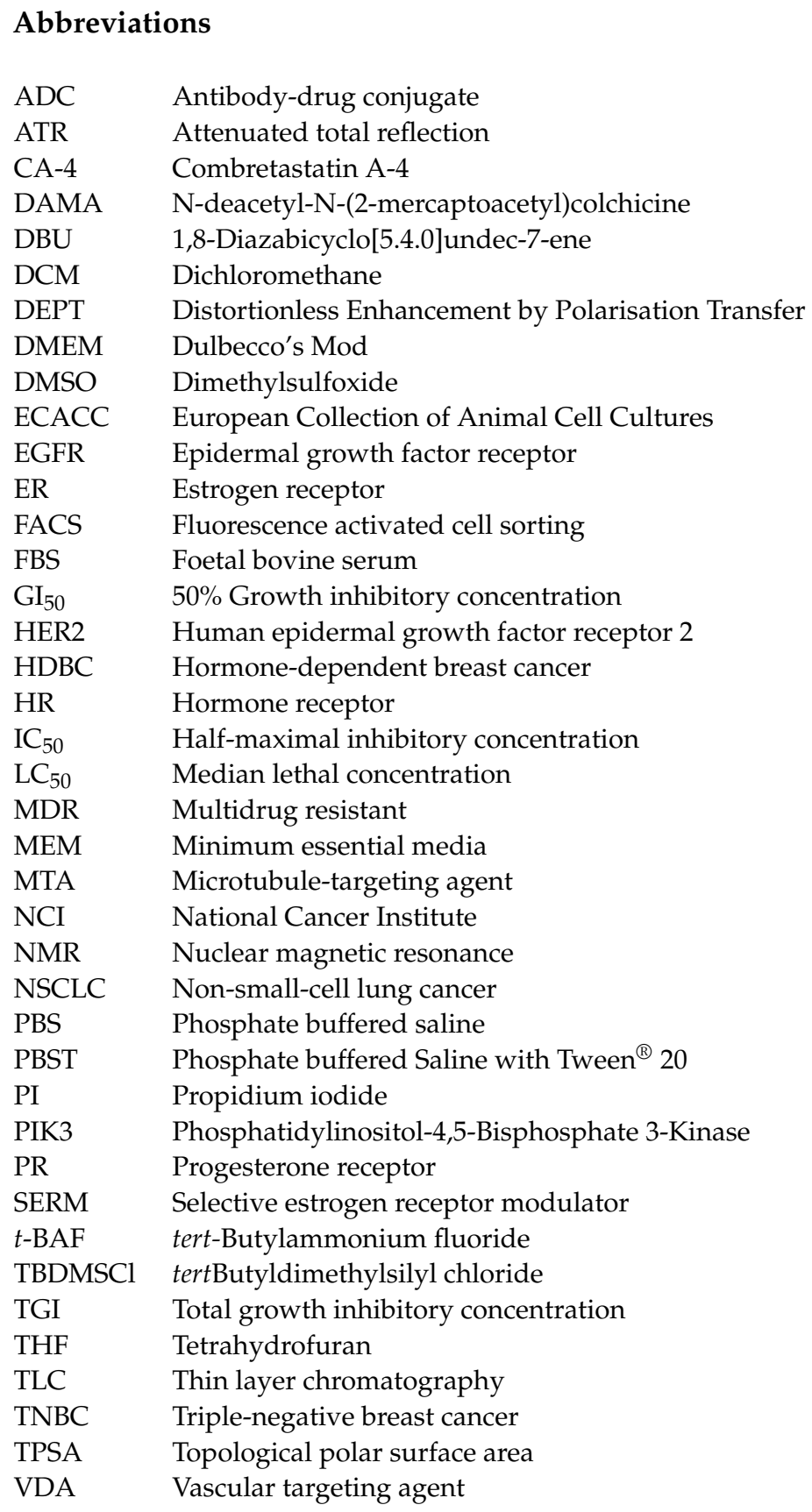

\section{References}

1. Steinmetz, M.O.; Prota, A.E. Microtubule-Targeting Agents: Strategies to Hijack the Cytoskeleton. Trends Cell Biol. 2018, 28, 776-792. [CrossRef]

2. Kaul, R.; Risinger, A.L.; Mooberry, S.L. Microtubule-Targeting Drugs: More than Antimitotics. J. Nat. Prod. 2019, 82, 680-685 [CrossRef]

3. Khongorzul, P.; Ling, C.J.; Khan, F.U.; Ihsan, A.U.; Zhang, J. Antibody-Drug Conjugates: A Comprehensive Review. Mol. Cancer Res. 2019, 18, 3-19. [CrossRef]

4. Prota, A.E.; Bargsten, K.; Díaz, J.F.; Marsh, M.; Cuevas, C.; Liniger, M.; Neuhaus, C.; Andreu, J.M.; Altmann, K.-H.; Steinmetz, M.O. A new tubulin-binding site and pharmacophore for microtubule-destabilizing anticancer drugs. Proc. Natl. Acad. Sci. USA 2014, 111, 13817-13821. [CrossRef]

5. Guo, H.; Li, X.; Guo, Y.; Zhen, L. An overview of tubulin modulators deposited in protein data bank. Med. Chem. Res. 2019, 28, 927-937. [CrossRef]

6. Ravelli, R.; Gigant, B.; Curmi, P.A.; Jourdain, I.; Lachkar, S.; Sobel, A.; Knossow, M. Insight into tubulin regulation from a complex with colchicine and a stathmin-like domain. Nature 2004, 428, 198-202. [CrossRef]

7. Slobodnick, A.; Shah, B.; Krasnokutsky, S.; Pillinger, M.H. Update on colchicine, 2017. Rheumatology 2018, 57, i4-i11. [CrossRef] 
8. Gracheva, I.A.; Shchegravina, E.S.; Schmalz, H.-G.; Beletskaya, I.P.; Fedorov, A.Y. Colchicine Alkaloids and Synthetic Analogues: Current Progress and Perspectives. J. Med. Chem. 2020, 63, 10618-10651. [CrossRef]

9. Majcher, U.; Klejborowska, G.; Kaik, M.; Maj, E.; Wietrzyk, J.; Moshari, M.; Preto, J.; Tuszynski, J.A.; Huczyński, A. Synthesis and Biological Evaluation of Novel Triple-Modified Colchicine Derivatives as Potent Tubulin-Targeting Anticancer Agents. Cells 2018, 7, 216. [CrossRef]

10. Greene, L.M.; Meegan, M.J.; Zisterer, D.M. Combretastatins: More than just vascular targeting agents? J. Pharmacol. Exp. Ther. 2015, 355, 212-227. [CrossRef]

11. Pettit, G.R.; Singh, S.B.; Hamel, E.; Lin, C.M.; Alberts, D.S.; Garcia-Kendal, D. Isolation and structure of the strong cell growth and tubulin inhibitor combretastatin A-4. Cell. Mol. Life Sci. 1989, 45, 209-211. [CrossRef]

12. Chase, D.M.; Chaplin, D.J.; Monk, B.J. The development and use of vascular targeted therapy in ovarian cancer. Gynecol. Oncol. 2017, 145, 393-406. [CrossRef]

13. Grisham, R.; Ky, B.; Tewari, K.S.; Chaplin, D.J.; Walker, J. Clinical trial experience with CA-4P anticancer therapy: Focus on efficacy, cardiovascular adverse events, and hypertension management. Gynecol. Oncol. Res. Pract. 2018, 5, 1. [CrossRef]

14. Karatoprak, G.; Akkol, E.K.; Genç, Y.; Bardakci, H.; Yücel, C.; Sobarzo-Sánchez, E. Combretastatins: An Overview of Structure, Probable Mechanisms of Action and Potential Applications. Molecules 2020, 25, 2560. [CrossRef] [PubMed]

15. Zhang, Y.; Zhang, Q.; Wei, F.; Liu, N. Progressive study of effects of erianin on anticancer activity. OncoTargets Ther. 2019, 12, 5457-5465. [CrossRef]

16. Pettit, G.R.; Toki, B.; Herald, D.L.; Verdier-Pinard, P.; Boyd, M.R.; Hamel, E.; Pettit, R.K. Antineoplastic Agents. 379. Synthesis of Phenstatin Phosphate. J. Med. Chem. 1998, 41, 1688-1695. [CrossRef]

17. Hamze, A.; Alami, M.; Provot, O. Developments of isoCombretastatin A-4 derivatives as highly cytotoxic agents. Eur. J. Med. Chem. 2020, 190, 112110. [CrossRef]

18. Aprile, S.; Del Grosso, E.; Tron, G.C.; Grosa, G. In vitro metabolism study of combretastatin A-4 in rat and human liver mi-crosomes. Drug Metab. Dispos. 2007, 35, 2252-2261. [CrossRef]

19. Gaspari, R.; Prota, A.E.; Bargsten, K.; Cavalli, A.; Steinmetz, M.O. Structural Basis of cis - and trans -Combretastatin Binding to Tubulin. Chem 2017, 2, 102-113. [CrossRef]

20. McLoughlin, E.C.; O'Boyle, N.M. Colchicine-binding site inhibitors from chemistry to clinic: A review. Pharmaceuticals 2020, 13, 8. [CrossRef]

21. La Regina, G.; Coluccia, A.; Naccarato, V.; Silvestri, R. Towards modern anticancer agents that interact with tubulin. Eur. J. Pharm. Sci. 2019, 131, 58-68. [CrossRef] [PubMed]

22. Arnst, K.E.; Wang, Y.; Hwang, D.-J.; Xue, Y.; Costello, T.; Hamilton, D.; Chen, Q.; Yang, J.; Park, F.; Dalton, J.T.; et al. A Potent, Metabolically Stable Tubulin Inhibitor Targets the Colchicine Binding Site and Overcomes Taxane Resistance. Cancer Res. 2017, 78, 265-277. [CrossRef]

23. Fu, D.-J.; Li, P.; Wu, B.-W.; Cui, X.-X.; Zhao, C.-B.; Zhang, S.-Y. Molecular diversity of trimethoxyphenyl-1,2,3-triazole hybrids as novel colchicine site tubulin polymerization inhibitors. Eur. J. Med. Chem. 2019, 165, 309-322. [CrossRef]

24. Naret, T.; Khelifi, I.; Provot, O.; Bignon, J.; Levaique, H.; Dubois, J.; Souce, M.; Kasselouri, A.; Deroussent, A.; Paci, A.; et al. 1,1-Diheterocyclic Ethylenes Derived from Quinaldine and Carbazole as New Tubulin-Polymerization Inhibitors: Synthesis, Metabolism, and Biological Evaluation. J. Med. Chem. 2018, 62, 1902-1916. [CrossRef]

25. Khelifi, I.; Pecnard, S.; Bernadat, G.; Bignon, J.; Levaique, H.; Dubois, J.; Provot, O.; Alami, M. Synthesis and Anticancer Properties of Oxazepines Related to Azaisoerianin and IsoCoQuines. ChemMedChem 2020, 15, 1571-1578. [CrossRef]

26. A Phase i/ii Trial of Crolibulin (epc2407) Plus Cisplatin in Adults with Solid Tumors with a Focus on Anaplastic Thyroid Cancer (atc). Available online: https:/ / clinicaltrials.gov/ct2/show/nct01240590 (accessed on 14 September 2021).

27. Zhang, Z.; Wang, C.; Ma, L.; Jiang, X.; Wu, C.; Wang, Y.; Jiang, Y.; Zheng, W.; Yang, Y.; Ma, Y.; et al. Molecular mechanism of crolibulin in complex with tubulin provides a rationale for drug design. Biochem. Biophys. Res. Commun. 2019, 511, 381-386. [CrossRef]

28. Wang, Y.; Zhang, H.; Gigant, B.; Yu, Y.; Wu, Y.; Chen, X.; Lai, Q.; Yang, Z.; Chen, Q.; Yang, J. Structures of a diverse set of colchicine binding site inhibitors in complex with tubulin provide a rationale for drug discovery. FEBS J. 2015, 283, 102-111. [CrossRef]

29. Tonra, J.R.; Lloyd, G.K.; Mohanlal, R.; Huang, L. Plinabulin ameliorates neutropenia induced by multiple chemotherapies through a mechanism distinct from G-CSF therapies. Cancer Chemother. Pharmacol. 2019, 85, 461-468. [CrossRef]

30. Blayney, D.W.; Zhang, Q.; Feng, J.; Zhao, Y.; Bondarenko, I.; Vynnychenko, I.; Kovalenko, N.; Nair, S.; Ibrahim, E.; Udovista, D.P.; et al. Efficacy of plinabulin vs pegfilgrastim for prevention of chemotherapy-induced neutropenia in adults with non-small cell lung cancer: A phase 2 randomized clinical trial. JAMA Oncol. 2020, 6, e204429. [CrossRef]

31. Bohnacker, T.; Prota, A.E.; Beaufils, F.; Burke, J.E.; Melone, A.; Inglis, A.J.; Rageot, D.; Sele, A.M.; Cmiljanovic, V.; Cmiljanovic, N.; et al. Deconvolution of buparlisib's mechanism of action defines specific pi3k and tubulin inhibitors for therapeutic intervention. Nat. Commun. 2017, 8, 14683. [CrossRef]

32. Ward, R.A.; Fawell, S.; Floc'H, N.; Flemington, V.; McKerrecher, D.; Smith, P.D. Challenges and Opportunities in Cancer Drug Resistance. Chem. Rev. 2020, 121, 3297-3351. [CrossRef]

33. O'Boyle, N.M.; Carr, M.; Greene, L.M.; Bergin, O.; Nathwani, S.M.; McCabe, T.; Lloyd, D.G.; Zisterer, D.M.; Meegan, M.J. Synthesis and Evaluation of Azetidinone Analogues of Combretastatin A-4 as Tubulin Targeting Agents. J. Med. Chem. 2010, 53, 8569-8584. [CrossRef] [PubMed] 
34. Malebari, A.M.; Fayne, D.; Nathwani, S.M.; O'Connell, F.; Noorani, S.; Twamley, B.; O’Boyle, N.M.; O'Sullivan, J.; Zisterer, D.M.; Meegan, M.J. Beta-lactams with antiproliferative and antiapoptotic activity in breast and chemoresistant colon cancer cells. Eur. J. Med. Chem. 2020, 189, 112050. [CrossRef] [PubMed]

35. Wang, S.; Malebari, A.M.; Greene, T.F.; O’Boyle, N.M.; Fayne, D.; Nathwani, S.M.; Twamley, B.; McCabe, T.; Keely, N.O.; Zisterer, D.M.; et al. 3-Vinylazetidin-2-Ones: Synthesis, Antiproliferative and Tubulin Destabilizing Activity in MCF-7 and MDA-MB-231 Breast Cancer Cells. Pharmaceuticals 2019, 12, 56. [CrossRef] [PubMed]

36. Carr, M.; Greene, L.M.; Knox, A.J.; Lloyd, D.G.; Zisterer, D.M.; Meegan, M.J. Lead identification of conformationally restricted beta-lactam type combretastatin analogues: Synthesis, antiproliferative activity and tubulin targeting effects. Eur. J. Med. Chem. 2010, 45, 5752-5766. [CrossRef]

37. O’Boyle, N.M.; Greene, L.M.; Bergin, O.; Fichet, J.-B.; McCabe, T.; Lloyd, D.G.; Zisterer, D.M.; Meegan, M.J. Synthesis, evaluation and structural studies of antiproliferative tubulin-targeting azetidin-2-ones. Bioorganic Med. Chem. 2011, 19, 2306-2325. [CrossRef] [PubMed]

38. Nathwani, S.M.; Hughes, L.; Greene, L.M.; Carr, M.; O’Boyle, N.M.; McDonnell, S.; Meegan, M.J.; Zisterer, D.M. Novel cisrestricted beta-lactam combretastatin A-4 analogues display anti-vascular and anti-metastatic properties in vitro. Oncol. Rep. 2013, 29, 585-594. [CrossRef]

39. Fu, D.J.; Zhang, Y.F.; Chang, A.Q.; Li, J. Beta-lactams as promising anticancer agents: Molecular hybrids, structure activity relationships and potential targets. Eur. J. Med. Chem. 2020, 201, 112510. [CrossRef]

40. Elmeligie, S.; Taher, A.T.; Khalil, N.A.; El-Said, A.H. Synthesis and cytotoxic activity of certain trisubstituted azetidin-2-one derivatives as a cis-restricted combretastatin A-4 analogues. Arch. Pharmacal Res. 2016, 40, 13-24. [CrossRef]

41. Banik, I.; Becker, F.F.; Banik, B.K. Stereoselective synthesis of beta-lactams with polyaromatic imines: Entry to new and novel anticancer agents. J. Med. Chem. 2003, 46, 12-15. [CrossRef]

42. Yang, Z. Synthesis and In Vitro Biological Activity Evaluation of the Derivatives of Combretastatin A-4. Lett. Drug Des. Discov. 2006, 3, 544-546. [CrossRef]

43. Borazjani, N.; Sepehri, S.; Behzadi, M.; Jarrahpour, A.; Rad, J.A.; Sasanipour, M.; Mohkam, M.; Ghasemi, Y.; Akbarizadeh, A.R.; Digiorgio, C.; et al. Three-component synthesis of chromeno beta-lactam hybrids for inflammation and cancer screening. Eur. J. Med. Chem. 2019, 179, 389-403. [CrossRef] [PubMed]

44. Chimento, A.; Sala, M.; Gomez-Monterrey, I.M.; Musella, S.; Bertamino, A.; Caruso, A.; Sinicropi, M.S.; Sirianni, R.; Puoci, F.; Parisi, O.I.; et al. Biological activity of 3-chloro-azetidin-2-one derivatives having interesting antiproliferative activity on human breast cancer cell lines. Bioorganic Med. Chem. Lett. 2013, 23, 6401-6405. [CrossRef]

45. Meenakshisundaram, S.; Manickam, S.; Vinayagam, V. Synthesis, antibacterial and anticancer activity of novel bisazetidinones. J. Chem. Pharm. Res. 2016, 8, 733-742.

46. Mohamadzadeh, M.; Zarei, M. Anticancer activity and evaluation of apoptotic genes expression of 2-azetidinones containing anthraquinone moiety. Mol. Divers. 2020, 1-11. [CrossRef]

47. Zhou, P.; Liu, Y.; Zhou, L.; Zhu, K.; Feng, K.; Zhang, H.; Liang, Y.; Jiang, H.; Luo, C.; Liu, M.; et al. Potent antitumor activities and structure basis of the chiral beta-lactam bridged analogue of combretastatin A-4 binding to tubulin. J. Med. Chem. 2016, 59, 10329-10334. [CrossRef]

48. Zhou, P.; Liang, Y.; Zhang, H.; Jiang, H.; Feng, K.; Xu, P.; Wang, J.; Wang, X.; Ding, K.; Luo, C.; et al. Design, synthesis, biological evaluation and cocrystal structures with tubulin of chiral b-lactam bridged combretastatin a-4 analogues as potent antitumor agents. Eur. J. Med. Chem. 2018, 144, 817-842. [CrossRef] [PubMed]

49. Tang, H.; Cheng, J.; Liang, Y.; Wang, Y. Discovery of a chiral fluorinated azetidin-2-one as a tubulin polymerisation inhibitor with potent antitumour efficacy. Eur. J. Med. Chem. 2020, 197, 112323. [CrossRef] [PubMed]

50. Tripodi, F.; Pagliarin, R.; Fumagalli, G.; Bigi, A.; Fusi, P.; Orsini, F.; Frattini, M.; Coccetti, P. Synthesis and Biological Evaluation of 1,4-Diaryl-2-azetidinones as Specific Anticancer Agents: Activation of Adenosine Monophosphate Activated Protein Kinase and Induction of Apoptosis. J. Med. Chem. 2012, 55, 2112-2124. [CrossRef] [PubMed]

51. Geesala, R.; Gangasani, J.K.; Budde, M.; Balasubramanian, S.; Vaidya, J.R.; Das, A. 2-Azetidinones: Synthesis and biological evaluation as potential anti-breast cancer agents. Eur. J. Med. Chem. 2016, 124, 544-558. [CrossRef]

52. Khanam, R.; Kumar, R.; Hejazi, I.I.; Shahabuddin, S.; Meena, R.; Jayant, V.; Kumar, P.; Bhat, A.R.; Athar, F. Piperazine clubbed with 2-azetidinone derivatives suppresses proliferation, migration and induces apoptosis in human cervical cancer hela cells through oxidative stress mediated intrinsic mitochondrial pathway. Apoptosis Int. J. Program. Cell Death 2018, 23, 113-131. [CrossRef] [PubMed]

53. Malashchuk, A.; Chernykh, A.V.; Hurmach, V.V.; Platonov, M.O.; Onopchenko, O.; Zozulya, S.; Daniliuc, C.G.; Dobrydnev, A.V.; Kondratov, I.S.; Moroz, Y.S.; et al. Synthesis, biological evaluation, and modeling studies of 1,3-disubstituted cyclobu-tanecontaining analogs of combretastatin A4. J. Mol. Struct. 2020, 1210, 128025. [CrossRef]

54. Fisher, J.F.; Mobashery, S. Beta-lactams against the fortress of the gram-positive staphylococcus aureus bacterium. Chem. Rev. 2021, 121, 3412-3463. [CrossRef] [PubMed]

55. Deep, A.; Kumar, P.; Narasimhan, B.; Lim, S.M.; Ramasamy, K.; Mishra, R.K.; Mani, V. 2-azetidinone derivatives: Synthesis, antimicrobial, anticancer evaluation and qsar studies. Acta Pol. Pharm. 2016, 73, 65-78. 
56. Mishra, M.K.; Singh, V.N.; Ahmad, K.; Sharma, S. Synthesis and antimicrobial activities of some novel diastereoselective monocyclic cis-beta-lactams using 2-ethoxycarbonyl DCPN as a carboxylic acid activator. Mol. Divers 2020, 25, $2073-2087$. [CrossRef]

57. Mohamadzadeh, M.; Zarei, M.; Vessal, M. Synthesis, in vitro biological evaluation and in silico molecular docking studies of novel beta-lactam-anthraquinone hybrids. Bioorg. Chem. 2020, 95, 103515. [CrossRef]

58. Walsh, O.; Meegan, M.; Prendergast, R.; Al Nakib, T. Synthesis of 3-acetoxyazetidin-2-ones and 3-hydroxyazetidin-2-ones with antifungal and antibacterial activity. Eur. J. Med. Chem. 1996, 31, 989-1000. [CrossRef]

59. Chhajed, S.S.; Manisha, P.; Bastikar, V.; Animeshchandra, H.; Ingle, V.; Upasani, C.; Wazalwar, S.S. Synthesis and molecular modeling studies of 3-chloro-4-substituted-1-(8-hydroxy-quinolin-5-yl)-azetidin-2-ones as novel anti-filarial agents. Bioorganic Med. Chem. Lett. 2010, 20, 3640-3644. [CrossRef] [PubMed]

60. Bhagat, S.; Sharma, N.; Chundawat, T.S. Synthesis of Some Salicylaldehyde-Based Schiff Bases in Aqueous Media. J. Chem. 2012, 2013, 1-4. [CrossRef]

61. Ahmadi, R.; Ebrahimzadeh, M.A. Resveratrol-A comprehensive review of recent advances in anticancer drug design and development. Eur. J. Med. Chem. 2020, 200, 112356. [CrossRef]

62. Elshaer, M.; Chen, Y.; Wang, X.J.; Tang, X. Resveratrol: An overview of its anti-cancer mechanisms. Life Sci. 2018, 207, 340-349. [CrossRef]

63. Pecyna, P.; Wargula, J.; Murias, M.; Kucinska, M. More than Resveratrol: New Insights into Stilbene-Based Compounds. Biomolecules 2020, 10, 1111. [CrossRef]

64. Chen, R.-J.; Kuo, H.-C.; Cheng, L.-H.; Lee, Y.-H.; Chang, W.-T.; Wang, B.-J.; Wang, Y.-J.; Cheng, H.-C. Apoptotic and Nonapoptotic Activities of Pterostilbene against Cancer. Int. J. Mol. Sci. 2018, 19, 287. [CrossRef]

65. Cooke, E.P.; Walsh, O.M.; Meegan, M.J. Reaction of mixed anhydrides with imines: Synthesis of 7-halogeno- and 7-azido-5-thia1-azabicyclo[4.2.0]octan-8-ones and 7-halogeno- and 7-azido-5-oxa-1-azabicyclo[4.2.0]octan-8-ones. J. Chem. Res. Synop. 1994, 26, 470-471. [CrossRef]

66. Jarrahpour, A.Z.; Zarei, M. Efficient one-pot synthesis of 2-azetidinones from acetic acid derivatives and imines using methoxymethylene-n,n-dimethyliminium salt. Tetrahedron 2010, 66, 5017-5023. [CrossRef]

67. Deketelaere, S.; Van Nguyen, T.; Stevens, C.V.; D'Hooghe, M. Synthetic approaches toward monocyclic 3-amino-beta-lactams. ChemistryOpen 2017, 6, 301-319. [CrossRef]

68. Pandey, S.; Thakur, A.; Reshma; Bari, S.S.; Thapar, R. Studies towards synthesis and Lewis acid catalysed functionalization of 3-(4'-substitutedphenylthio)-azetidin-2-ones. J. Chem. Sci. 2020, 132, 1-11. [CrossRef]

69. Spek, A.L.; Van Der Steen, F.H.; Jastrzebski, J.T.B.H.; Van Koten, G. trans-3-Amino-1-methyl-4-phenyl-2-azetidinone, C10H12N2O. Acta Crystallogr. Sect. C Cryst. Struct. Commun. 1994, 50, 1933-1935. [CrossRef]

70. Kabak, M.; Senoz, H.; Elmali, A.; Adar, V.; Svoboda, I.; Dusek, M.; Fejfarova, K. Synthesis and X-ray crystal structure determination of N-p-methylphenyl-4-benzoyl-3,4-diphenyl-2-azetidinone. Crystallogr. Rep. 2010, 55, 1220-1222. [CrossRef]

71. Lara-Ochoa, F.; Espinosa-Pérez, G. A new synthesis of combretastatins A-4 and AVE-8062A. Tetrahedron Lett. 2007, 48, 7007-7010. [CrossRef]

72. Casadei, M.A.; Inesi, A.; Moracci, F.M.; Occhialini, D. Electrochemical studies on b-lactams. Part 4. Electroacetylation of b-lactams. Tetrahedron 1989, 45, 6885-6890. [CrossRef]

73. Decamps, S.; Sevaille, L.; Ongeri, S.; Crousse, B. Access to novel functionalized trifluoromethyl beta-lactams by ring expansion of aziridines. Org. Biomol. Chem. 2014, 12, 6345-6348. [CrossRef] [PubMed]

74. Malebari, A.M.; Greene, L.M.; Nathwani, S.M.; Fayne, D.; O’Boyle, N.M.; Wang, S.; Twamley, B.; Zisterer, D.M.; Meegan, M.J. Beta-lactam analogues of combretastatin a-4 prevent metabolic inactivation by glucuronidation in chemoresistant HT-29 colon cancer cells. Eur. J. Med. Chem. 2017, 130, 261-285. [CrossRef]

75. Su, M.; Huang, J.; Liu, S.; Xiao, Y.; Qin, X.; Liu, J.; Pi, C.; Luo, T.; Li, J.; Chen, X.; et al. The anti-angiogenic effect and novel mechanisms of action of Combretastatin A-4. Sci. Rep. 2016, 6, 28139. [CrossRef] [PubMed]

76. Baell, J.B.; Nissink, J.W.M. Seven Year Itch: Pan-Assay Interference Compounds (PAINS) in 2017-Utility and Limitations. ACS Chem. Biol. 2017, 13, 36-44. [CrossRef] [PubMed]

77. Yao, H.; He, G.; Yan, S.; Chen, C.; Song, L.; Rosol, T.J.; Deng, X. Triple-negative breast cancer: Is there a treatment on the horizon? Oncotarget 2017, 8, 1913-1924. [CrossRef] [PubMed]

78. Cipriano, C.; Mesquita, A. Emerging Therapeutic Drugs in Metastatic Triple-Negative Breast Cancer. Breast Cancer Basic Clin. Res. 2021, 15. [CrossRef] [PubMed]

79. Ma, M.; Sun, L.; Lou, H.; Ji, M. Synthesis and biological evaluation of Combretastatin A-4 derivatives containing a 3'-O-substituted carbonic ether moiety as potential antitumor agents. Chem. Central J. 2013, 7, 179. [CrossRef] [PubMed]

80. Hughes, L.; Malone, C.; Chumsri, S.; Burger, A.M.; McDonnell, S. Characterisation of breast cancer cell lines and establishment of a novel isogenic subclone to study migration, invasion and tumourigenicity. Clin. Exp. Metastasis 2008, 25, 549-557. [CrossRef]

81. Ma, J.; Wang, S.; Zhao, M.; Deng, X.-S.; Lee, C.-K.; Yu, X.-D.; Liu, B. Therapeutic potential of cladribine in combination with STAT3 inhibitor against multiple myeloma. BMC Cancer 2011, 11, 255. [CrossRef]

82. Sengmany, S.; LeGall, E.; LeJean, C.; Troupel, M.; Nedelec, J. Straightforward three-component synthesis of diarylmethylpiperazines and 1,2-diarylethylpiperazines. Tetrahedron 2007, 63, 3672-3681. [CrossRef] 
83. He, J.; Zhang, M.; Tang, L.; Liu, J.; Zhong, J.; Wang, W.; Xu, J.-P.; Wang, H.-T.; Li, X.-F.; Zhou, Z.-Z. Synthesis, Biological Evaluation, and Molecular Docking of Arylpyridines as Antiproliferative Agent Targeting Tubulin. ACS Med. Chem. Lett. 2020, 11, 1611-1619. [CrossRef] [PubMed]

84. National Cancer Institute. Biological Testing Branch. Available online: dtp.Cancer.Gov (accessed on 15 September 2021).

85. Yu, S.; Kim, T.; Yoo, K.H.; Kang, K. The T47D cell line is an ideal experimental model to elucidate the progesterone-specific effects of a luminal A subtype of breast cancer. Biochem. Biophys. Res. Commun. 2017, 486, 752-758. [CrossRef] [PubMed]

86. Medarde, M.; Maya, A.B.; Pérez-Melero, C. Review ArticleNaphthalene Combretastatin Analogues: Synthesis, Cytotoxicity and Antitubulin Activity. J. Enzym. Inhib. Med. Chem. 2004, 19, 521-540. [CrossRef]

87. Smith, S.M.; Wunder, M.B.; Norris, D.A.; Shellman, Y.G. A Simple Protocol for Using a LDH-Based Cytotoxicity Assay to Assess the Effects of Death and Growth Inhibition at the Same Time. PLoS ONE 2011, 6, e26908. [CrossRef] [PubMed]

88. O’Boyle, N.M.; Carr, M.; Greene, L.M.; Keely, N.; Knox, A.; McCabe, T.; Lloyd, D.; Zisterer, D.M.; Meegan, M.J. Synthesis, biochemical and molecular modelling studies of antiproliferative azetidinones causing microtubule disruption and mitotic catastrophe. Eur. J. Med. Chem. 2011, 46, 4595-4607. [CrossRef]

89. Cytoskeleton. Available online: www.Cytoskeleton.Com/tubulin-resources (accessed on 15 September 2021).

90. Vitale, I.; Antoccia, A.; Cenciarelli, C.; Crateri, P.; Meschini, S.; Arancia, G.; Pisano, C.; Tanzarella, C. Combretastatin CA-4 and combretastatin derivative induce mitotic catastrophe dependent on spindle checkpoint and caspase-3 activation in non-small cell lung cancer cells. Apoptosis 2006, 12, 155-166. [CrossRef]

91. O’Boyle, N.M.; Ana, G.; Kelly, P.M.; Nathwani, S.M.; Noorani, S.; Fayne, D.; Bright, S.A.; Twamley, B.; Zisterer, D.M.; Meegan, M.J. Synthesis and evaluation of antiproliferative microtubule-destabilising combretastatin A-4 piperazine conjugates. Org. Biomol. Chem. 2019, 17, 6184-6200. [CrossRef]

92. Mc Gee, M.M. Targeting the Mitotic Catastrophe Signaling Pathway in Cancer. Mediat. Inflamm. 2015, 2015, 1-13. [CrossRef]

93. Fortin, S.; Lacroix, J.; Côté, M.-F.; Moreau, E.; Petitclerc, E.C.; Gaudreault, R. Quick and Simple Detection Technique to Assess the Binding of Antimicrotubule Agents to the Colchicine-Binding Site. Biol. Proced. Online 2010, 12, 113-117. [CrossRef] [PubMed]

94. Zhu, T.; Wang, S.-H.; Li, D.; Wang, S.-Y.; Liu, X.; Song, J.; Wang, Y.-T.; Zhang, S.-Y. Progress of tubulin polymerization activity detection methods. Bioorganic Med. Chem. Lett. 2021, 37, 127698. [CrossRef]

95. Pena-Blanco, A.; Garcia-Saez, A.J. Bax, bak and beyond-Mitochondrial performance in apoptosis. FEBS J. 2018, $285,416-431$. [CrossRef] [PubMed]

96. Kale, J.; Osterlund, E.J.; Andrews, D. BCL-2 family proteins: Changing partners in the dance towards death. Cell Death Differ. 2017, 25, 65-80. [CrossRef]

97. Yamaguchi, R.; Lartigue, L.; Perkins, G. Targeting Mcl-1 and other Bcl-2 family member proteins in cancer therapy. Pharmacol. Ther. 2018, 195, 13-20. [CrossRef] [PubMed]

98. Thomas, L.W.; Lam, C.; Edwards, S.W. Mcl-1; the molecular regulation of protein function. FEBS Lett. 2010, 584, 2981-2989. [CrossRef] [PubMed]

99. Wei, Y.; Cao, Y.; Sun, R.; Cheng, L.; Xiong, X.; Jin, X.; He, X.; Lu, W.; Zhao, M. Targeting bcl-2 proteins in acute myeloid leu-kemia. Front. Oncol. 2020, 10, 584974. [CrossRef] [PubMed]

100. McBride, A.; Houtmann, S.; Wilde, L.; Vigil, C.; Eischen, C.M.; Kasner, M.; Palmisiano, N. The Role of Inhibition of Apoptosis in Acute Leukemias and Myelodysplastic Syndrome. Front. Oncol. 2019, 9, 192. [CrossRef]

101. Chemical Computing Group Inc. Molecular Operating Environment (MOE); Version 2019.01; Chemical Computing Group Inc.: Montreal, QC, Canada, 2019.

102. Greene, T.F.; Wang, S.; Greene, L.M.; Nathwani, S.M.; Pollock, J.K.; Malebari, A.M.; McCabe, T.; Twamley, B.; O’Boyle, N.M.; Zisterer, D.M.; et al. Synthesis and biochemical evaluation of 3-phenoxy-1,4-diarylazetidin-2-ones as tubulin-targeting anti-tumor agents. J. Med. Chem. 2016, 59, 90-113. [CrossRef]

103. Cushman, M.; Nagarathnam, D.; Gopal, D.; Chakraborti, A.K.; Lin, C.M.; Hamel, E. Synthesis and evaluation of stilbene and dihydrostilbene derivatives as potential anticancer agents that inhibit tubulin polymerization. J. Med. Chem. 1991, 34, 2579-2588. [CrossRef]

104. Promega Corporation, Cytotox 96®Non-Radioactive Cytotoxicity Assay. Promega Cytotox 96 Non-Radioactive Cytotoxicity Assay Protocol. 2016. Available online: worldwide.Promega.Com/products/cell-health-assays/cell-viability-and-cytotoxicityassays / cytotox-96-non_radioactive-cytotoxicity-assay/?Catnum=g1780 (accessed on 14 September 2021).

105. Riccardi, C.; Nicoletti, I. Analysis of apoptosis by propidium iodide staining and flow cytometry. Nat. Protoc. 2006, 1, 1458-1461. [CrossRef]

106. Vermes, I.; Haanen, C.; Reutelingsperger, C. Flow cytometry of apoptotic cell death. J. Immunol. Methods 2000, 243, 167-190. [CrossRef]

107. Bruker Apex v2014. Bruker AXS Inc.: Madison, WI, USA.

108. Sheldrick, G.M. SADABS. Bruker AXS Inc.: Madison, WI, USA; University of Göttingen: Göttingen, Germany, 2014.

109. Sheldrick, G.M. Crystal structure refinement withSHELXL. Acta Crystallogr. Sect. C Struct. Chem. 2015, 71, 3-8. [CrossRef] [PubMed]

110. Dolomanov, O.V.; Bourhis, L.J.; Gildea, R.; Howard, J.A.K.; Puschmann, H. OLEX2: A complete structure solution, refinement and analysis program. J. Appl. Crystallogr. 2009, 42, 339-341. [CrossRef]

111. Omega 4.1.0.2: Openeye Scientific Software Inc. Available online: www.Eyesopen.Com (accessed on 14 September 2021). 
112. Hawkins, P.C.D.; Skillman, A.G.; Warren, G.L.; Ellingson, B.A.; Stahl, M.T. Conformer Generation with OMEGA: Algorithm and Validation Using High Quality Structures from the Protein Databank and Cambridge Structural Database. J. Chem. Inf. Model. 2010, 50, 572-584. [CrossRef]

113. McGann, M. FRED Pose Prediction and Virtual Screening Accuracy. J. Chem. Inf. Model. 2011, 51, 578-596. [CrossRef] [PubMed]

114. Sabizabulin for COVID-19. Available online: https://verupharma.com/pipeline/sabizabulin-for-covid-19/ (accessed on 29 September 2021). 